\title{
دور التربية في الحفاظ على الطبقة الوسطى في المجتمع المصري
}

\author{
د. / اساسر عبد الحافظ على \\ أستاذ أصول التربية المساعد \\ كلية التربية- الإسماعيلية- جامعة قناة السويس
}

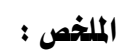

يهذف البحث إلى وضع تصور مقترح للحفاظ على الطبقة الوسطى من التآكل والإنكماش

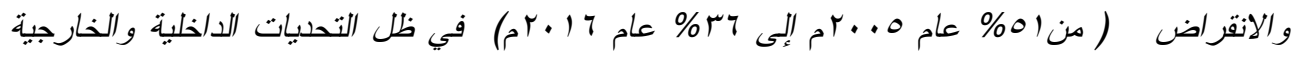

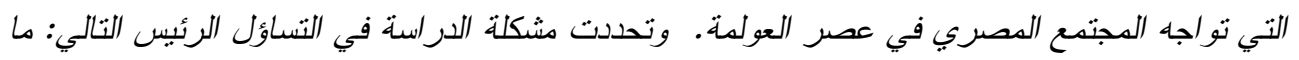

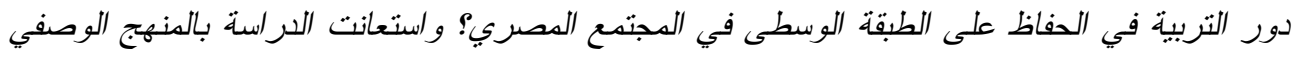

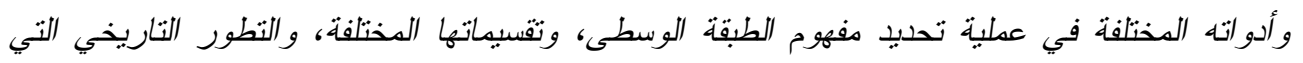

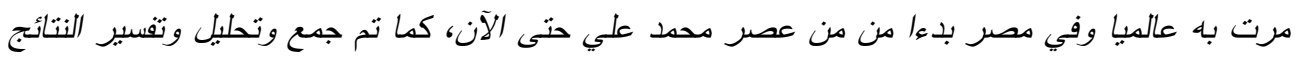

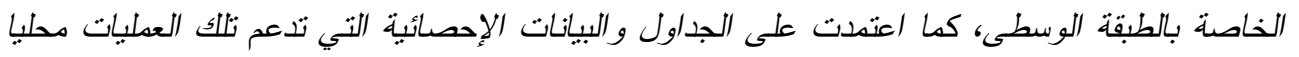

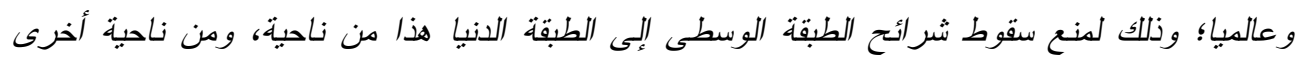

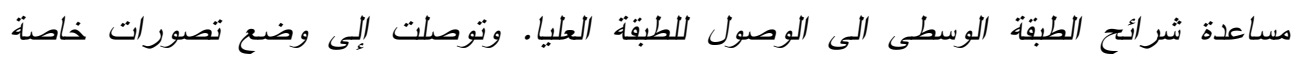

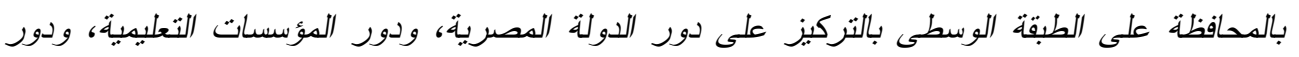

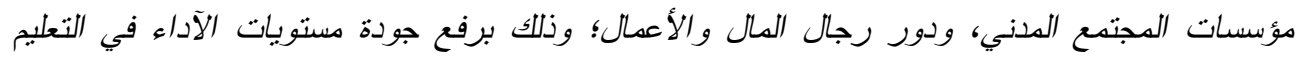

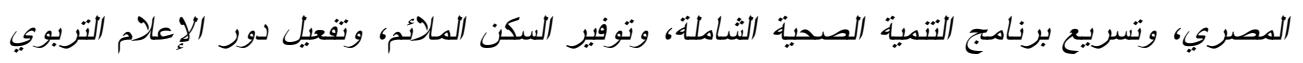

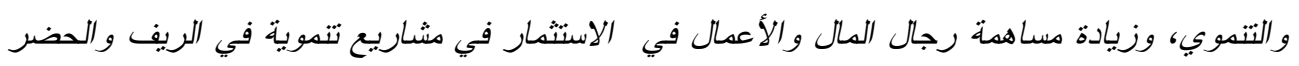

لأبناء الطبقة الوسطى. وزئ.

\section{Abstract}

The study aims to provide a proposed a framework for preserve the middle class from erosion, contraction and extinction (from 51\% in 2005 to $36 \%$ in 2016) in light of the internal and external challenges facing the Egyptian society in the era of globalization. To solve the study problem, the following key question was answered: What is the role of education in preserving the middle class in the Egyptian society? The study adopted the descriptive approach and its various tools to determine the concept of the middle class, its different divisions and historical development globally and in Egypt, from the era of Muhammad Ali till now. Results related to the middle class were collected, analyzed and interpreted using statistical methods that support these processes locally and globally so as to prevent 
the fall of the middle-class segments into the lower classes and to help these segments to reach the upper classes. The study proposed a framework for the preservation of the middle class by focusing on the role of the Egyptian State, educational institutions, the civil society institutions, and businessmen in enhancing the quality of performance levels of Egyptian education, accelerating the comprehensive health development program, providing adequate housing, and activating the role of educational and developmental media, and increasing the contribution of businessmen in investment in rural and urban development projects for the middle class.

فر انسيس بيكـون Francis Bacon" : " إن

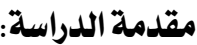

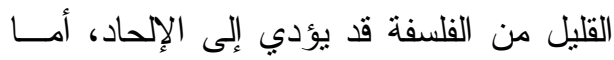

التعمق فيها فإنه يؤدي إلــى الإيمــان بــالله"

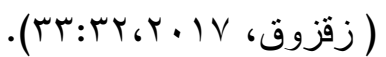

وجعل اله العقل على ثلاث مراتـب:

عقل سطحي، وعقل عميق، وعقل مسستنير؛

فالعقل المستتير ينتج الإيمان و العمر ان، و أمســا

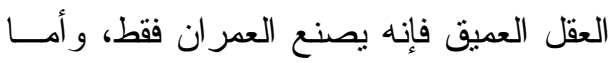

العقل السطحي فإنه لايصنع عمر انا و لا يزداد

لقد خلق الله الإنسان وميزه عن سائر

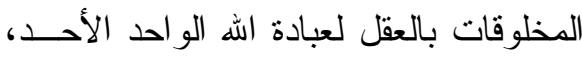

و هيأ له الكون على هيئة الصلاح، ليزيــــه

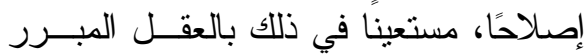

الفطن الذي يملك الحُجة و الدليل و البرهــان

العقلي والعملي. ولكن واجهــت الإنـسـان

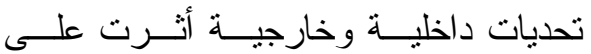

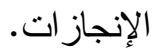

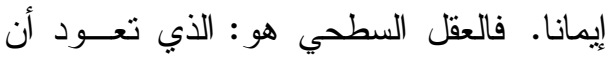

يقف عند ظواهر الأمور، ويكتفي بإدراكهـا،

دون فكر و لا تحليـل فهـــو مسـشغول دائــــا

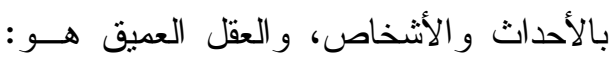

الذي يدرس الظاهرة منْ أين بدأت؟ وكيــ فئف

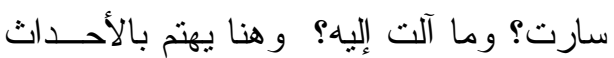

بالأشخاص و الوقائع ، و العقل الدسـتنتير هو :

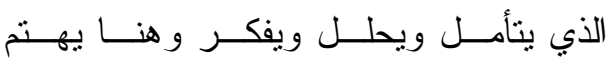

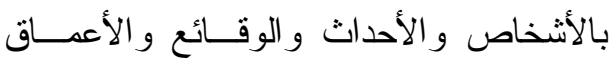

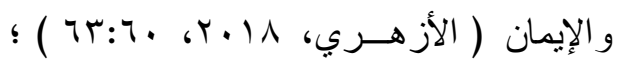

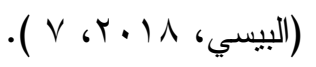

Rene " يقـول" رينيـــه ديكــــارت

Descartes

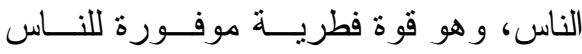

جميعًا، وهو الذوق السليم، وهو القوة علــى هوهى

الحكم الصحيح وتمييز الحق مــن الباطــل، وهـل،

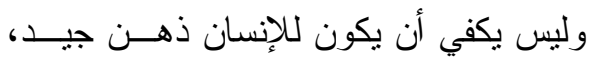

ولكن الأهم أن نــستعمله اســتعمالاً جيـــــاً

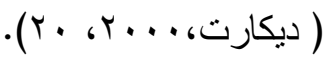

ويقول الإمام " محمد عبــده " : " إن

در اسة العلوم العقلية تعد ضرورة لا غنـى

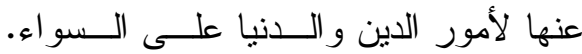

ويقول الفيلسوف الإنجليـزيـي المعـروف " 


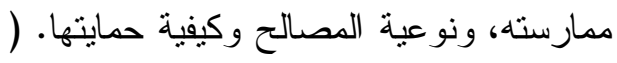

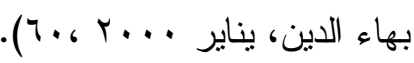

وتؤدى العولمة Globalization إلـى عالم خُمسه فقط يتمتـــع بـــالغنى و الرفاهيــة، و الباقى يعيش على الهامش بــالفقر و اللهــاث

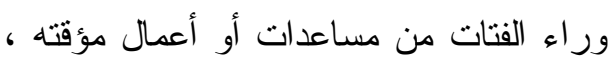

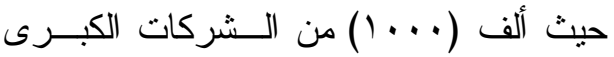
متعددة الجنسيات تسيطر على أكثر من نصف

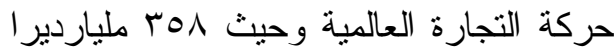
عالميا بملكون ما يملكــهـه مليــارين ونــــف إنسان علـى كوكبنــا الكـــرة الارضـــية. ( بوكسبرجر و كلمينتا ، 999 (1، ) ). ومن هذا المنطلق فهنالك حرب حتميــة وشيكه - على حد قول " روجيه جـارودي" هلي" Roger Garaudy سوف يزدادون غنى وفقراؤه سوف يزدادون

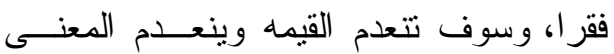
وسوف يسيطر العبــث و المتعـــة و اللحظــــة العابرة على كل شيء( مــصطفى محمــود ،

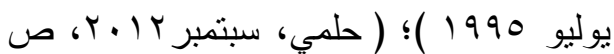
7 ())؛ ويؤكد ما سبق مقولة رئـسبس وزر اء

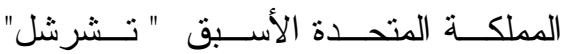
Churchill الثهيرة : إن حكم العالم يجب أن يكون للاول التىى أثنبعت حاجاتها ، ولو نرك حكم العالم للشعوب الجوعى لكان هناك خطر لألى

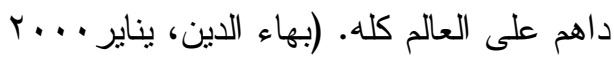
، ، 7). ويتفق " توماس فريدمان " Thomas

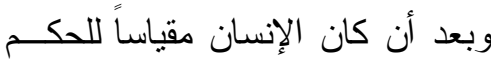
على الأثباء طبقا لمقولة الفيلسوف اليوناني "بورتاجور اس"، وبعد أن كان النص الديني هو مقياس الحكم على الأشياء في العصور

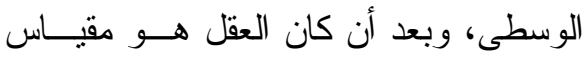
الحكم على الأشياء في الحضارة الغربية،

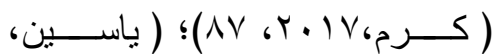

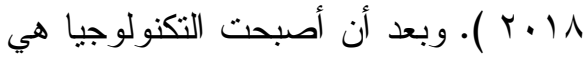
مقياس الحكم على الأثياء وتحول الإنـسان من حيوان ناطق إلى حيو ان ضــاحكى إلــى

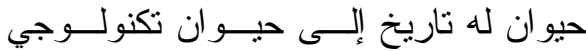

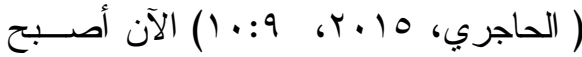
- تقريبا- المال هو مقيــاس الحكــم علـى

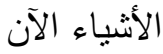

و هناك الآن من يتتافسون مالياً فيمــا

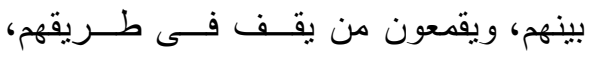
يساعدهم فى ذلك الأغنياء فى الدول الفقيرة ، والآخرون يخدمون ويطيعون ويتحملون. و على حد تعبير " نعوم تشومسكى Noam

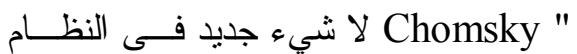

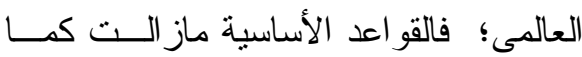
هى: قو اعد القانون للضعفاء، وسطوة القوة

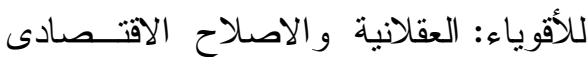

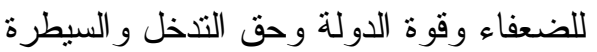

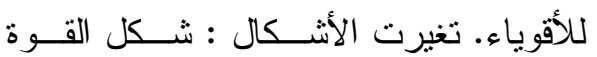

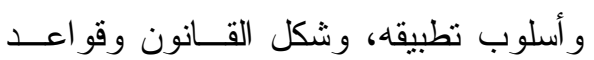


هي أولى بيروقر اطيــات مجتمــع التـــنيع

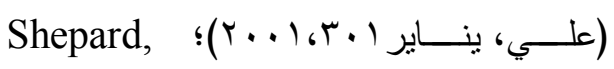

(1990, 357-360)

ويشير "طه حسين" إلى أن التعليم قــوة

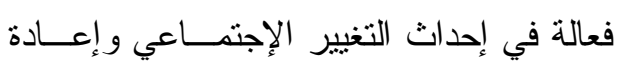

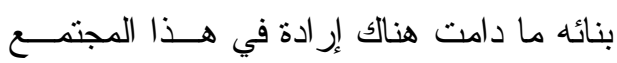

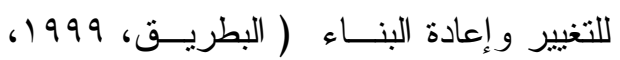

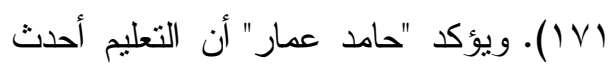

من بين ما أحدث، حر اكا اجتماعيا ملحوظا-

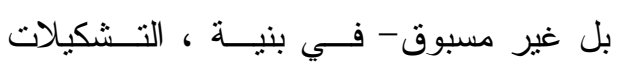

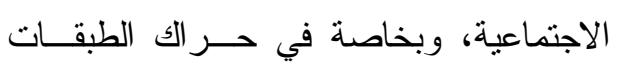
الدنيا و الوسطى، تأسيسا وترسيخا لمبدأ العدل

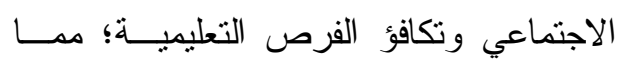
أعطى وجوه الفقر اء مـسحة مــن الكبريــاء

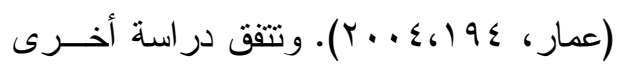
على ذلك أي على أن النعليم يؤدي دور ا مهمًا

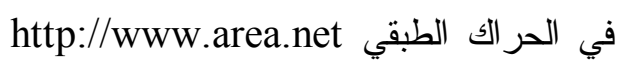

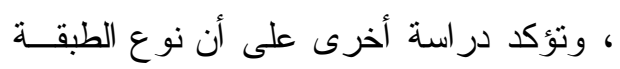

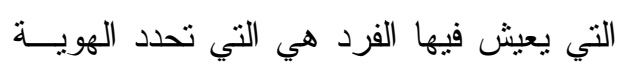

(Smith, 2012)

وتتفق إحدى الدراسات مع ذللك، حيث

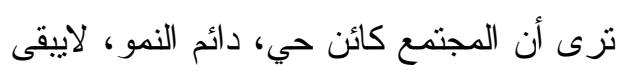

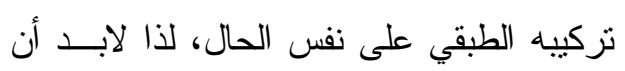

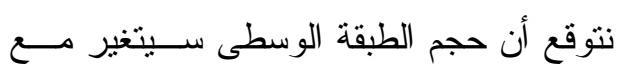

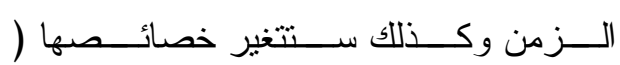

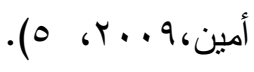

منطلقات الدراسة:
Friedman مع ما سبق، حيث يقول:" إن

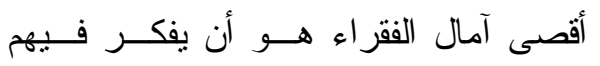

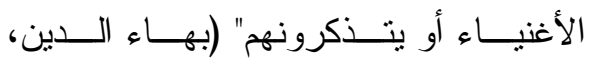

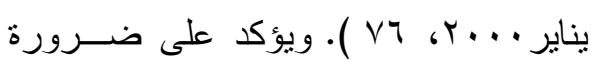

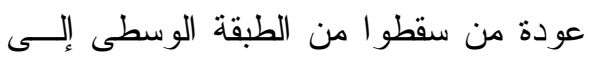

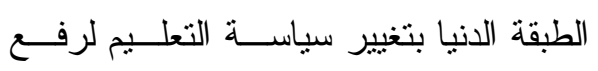
مهار اتهم ورفع أجور هم و الاستعانة بالتليفون المحمول ( Manyika, 2019 ) ومن هنا يتــضـح أن هنــالك بـــو ادر

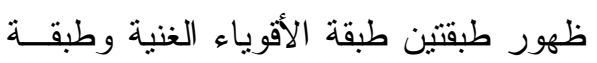

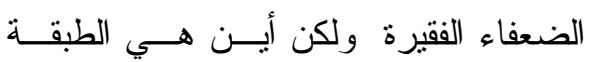
الوسطى النى هى قلب و عقل أى مجتمع من هن المجتمعات؟ وتــثير الدراســات العالميــة إلـى انخفاض حجم الطبقة الوسطى فـي V دول أوروبية هي: الدانمرك، وفنلندا، و إيطاليــا، ولكسمبورج، و النرويج، و أسبانيا، و ألمانيــا.

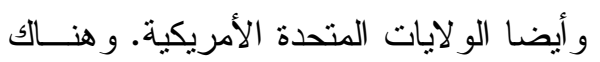
ارتفاع ملحوظ للطبقة الوسطى في فرنسا،

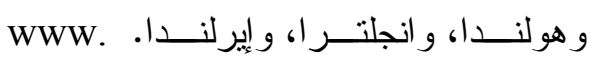
Investopedia.Com.Jun25.2019 لقد أولت نمط التزبية عند " فر انسيس بيكون" Francis Bacon اهتمامها لأبنــاء الطبقة الوسطى: تلبية لمطالب سوق العمل، لبكون

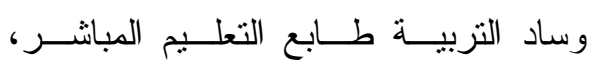
و أصبحت المدارس مصانع إنتاج لاكـسـاب المهار ات، وبذلك تصبح المدرسة-كما قيل- 
الصفوف الأولى، بينما يجلس طـــلاب

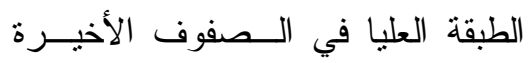
( منصور، (94)

ا - مصر في التزتيب (^^) دوليا من بين

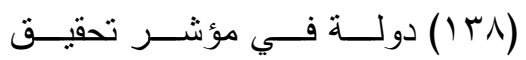

المتطلبات الأساسية من صحة و التعليم

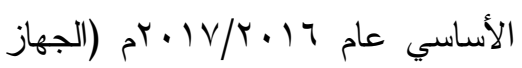

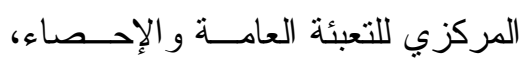

Capmas.Gov.eg مؤشرات دولية

WWW. 25/8/2018

V- مصر في الترتيب (r/I) دوليا مسن

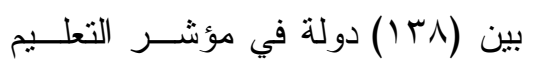

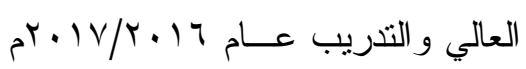

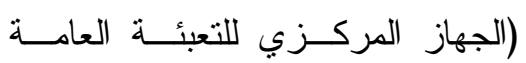

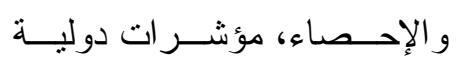

Capmas. Gov.eg 25/8/2018

WWW.

\section{مشكلة الدراسة:}

مع نز اجع معـــلات التـضخم فـي

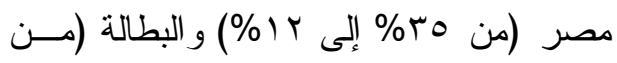

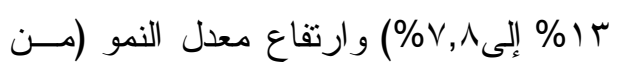

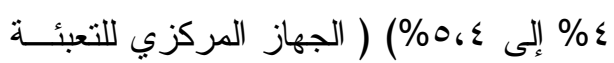

العامة و الإحصاء، إحصاءات تحت المجهر المراز المركزئ

( . Capmas.Gov.eg 25/8/2019

لم تتعر طبقات المجتمع المصري- WWW

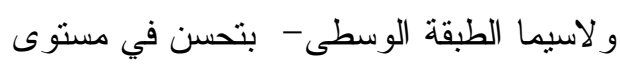

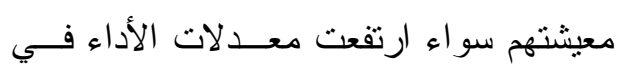

1 - ينقسم أي مجتمع إلى ثلاث طبقـــات:

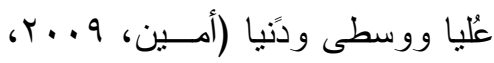

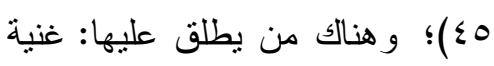

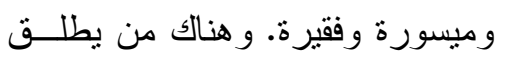

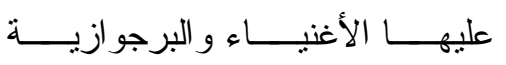

و البروليتاريا ( عبد الفضيل، • 191 ()).

r- توجد عدة معايير لتقـسيم طبقــات

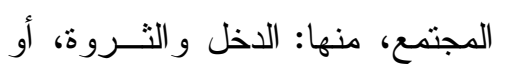

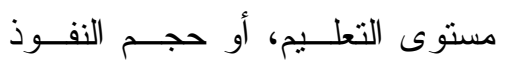

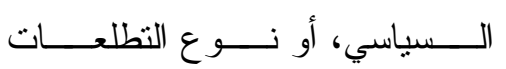

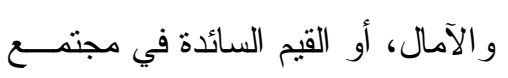

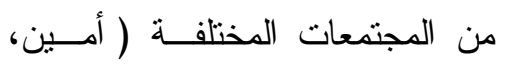

\&)

. () 5

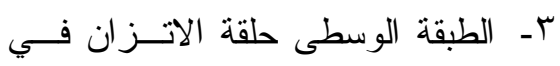

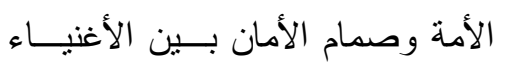

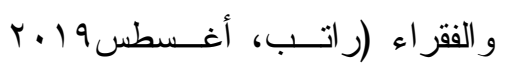

. (IT。

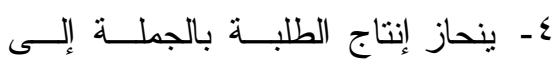

الطالب المتوسط على حساب الطالب

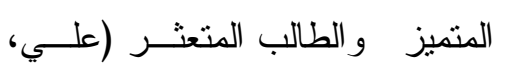

. (r. 1, r..)

0ـ يجلس - غالباً - طــلاب ل الطبقـــة

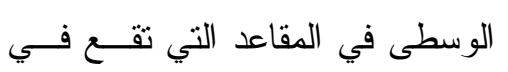

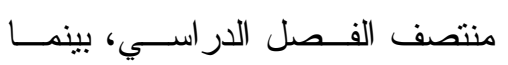

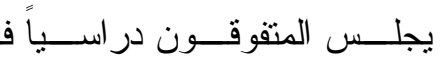




$$
\begin{aligned}
& \text { الوسطى إلى الطبقات العليــا وبالتــالي فــإن }
\end{aligned}
$$

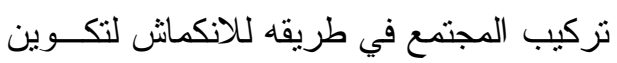

$$
\begin{aligned}
& \text { طبقة عليا وطبقة دنيا، ولكن ماذا عن الطبقــــة } \\
& \text { الوسطى؟ } \\
& \text { في ضو ء مـــا ســق، مــا مـسـتقبل } \\
& \text { الطبقة الوسطى في المجتمع المصري في ظل فل في }
\end{aligned}
$$

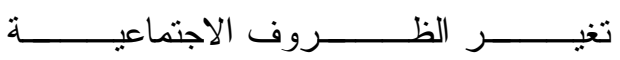

$$
\begin{aligned}
& \text { و الاقتصادية؟ }
\end{aligned}
$$

ومن هذا السؤال الرئيس تتبثق الأسئلة

1 - ما واقع تطور الطبقة الوســـى فـي

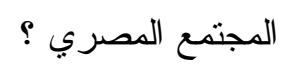

r- - ما أسباب تدهور الطبقة الوسطى فـي

$$
\text { المجتمع المصري؟ }
$$

r- ما دور التزبية في الحفاظ على الطبقة

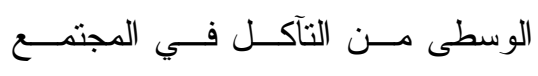

$$
\text { المصري؟ }
$$

\section{أهداف الدراسة:}

$$
1 \text { - تحديد مفهوم الطبقة الوسطى. }
$$

r- - تحديد أسباب تدهور الطبقة الوسطى في

$$
\text { المجتمع المصري. }
$$

r- وضع نصور مقترح لدور التربية فـي الحفاظ على الطبقة الوسطى من التآكل

$$
\text { في المجتمع المصري. }
$$

الاقتصاد المصري أم لم ترتفع، بل حـدثت

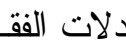

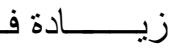

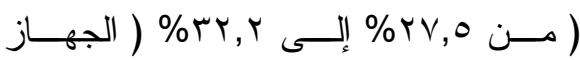

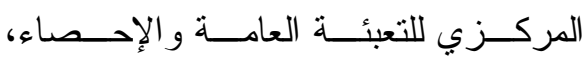

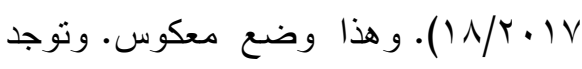

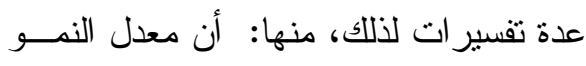

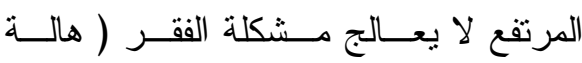

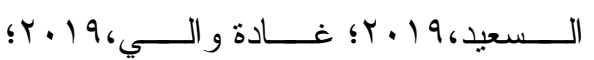

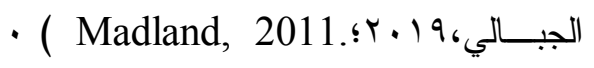
ومن هذه التفسيرات - أيضـا- أن عمليــة

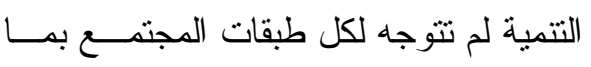
فيهم غير القادرين ، أو بلغة سوســيولوجية لفئية

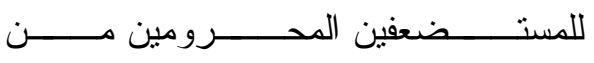
القوة Powerless People، بما تـضمهر من فقر اء ومهمــشين ومحــدودي الــدخل

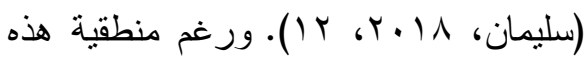

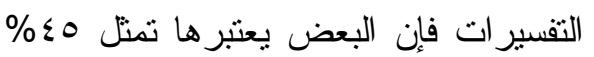

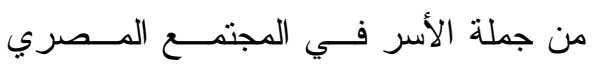

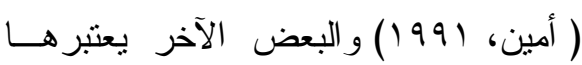

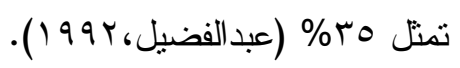

ونظر الرفع الدعم تدريجيًا عن معظم

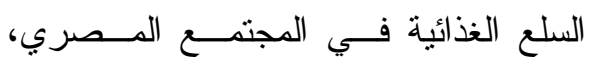

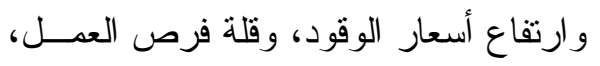

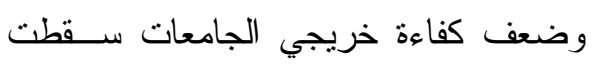
بعض الأسر من الطبقات الوســطى إلـى لـى

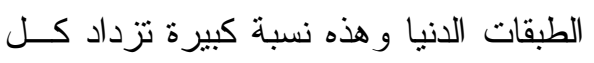

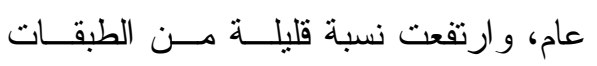


ميل" Madland, John Stuart Mill

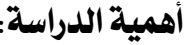

( 2011 )

I- الطبقة الوسطى هي العمود الفقــري

T- الطبقة التي ينتمي إليها الفـرد تحــدد

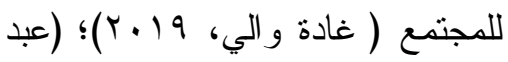

نمط التعليم ( Manstead, 2018 ) ؛

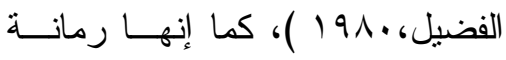

(Reary, et all, 2113.)

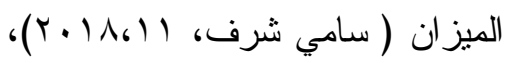

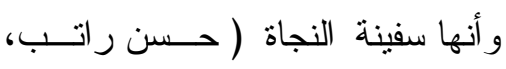

$$
.(r \cdot 196) r
$$

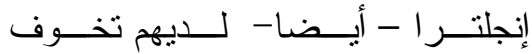

و غموض و اختلافات مــن الخصــصة

و اقتصاديات السوق و المبادرات المالية

في التعليم العام و التعلــيم الحكــومي

(Crozier, Reay, \& James,

2008, 262-271)

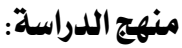

اعتمدت الدراسة على المنهج الوصفي

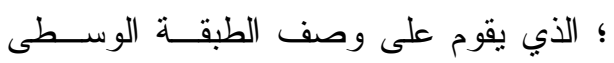

وتحليلها تحليلا اجتماعيا للطبقات وللـشـر ائح

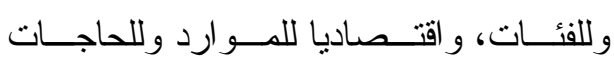
وللتكلفة وللانفاق، و احصائياً للجداول وللأرقام

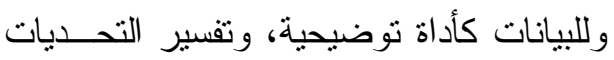

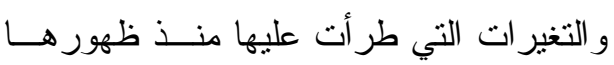

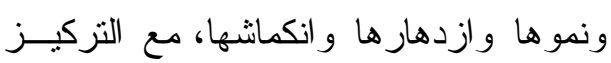

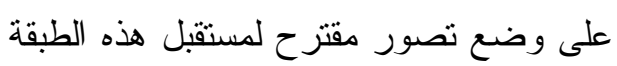

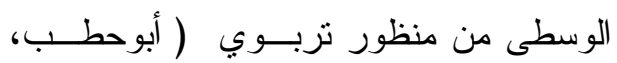

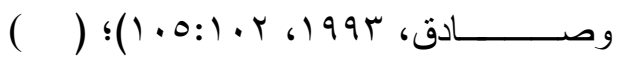

) ؛ichberger, 1989,173-176

(Borg, 1980, 129-132

r- الطبقة الوسطى بها تتحقــق العدالـــة

الاجتماعية بين الأفر اد، وبدونها ينشأ

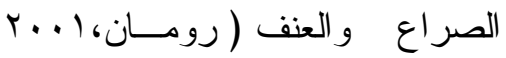

. ( ) \&。

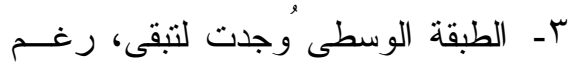

التحديات الجسيمة التى و اجهتها فــي

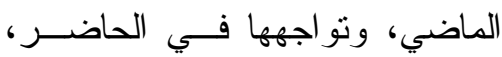

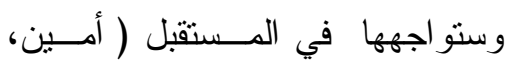

. ( . r. . 9

ـــ الطبقة الوسطى هـي الأقــلـ فـي

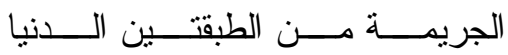

و الوسطى، ولديهم مستوى عال مـنـ

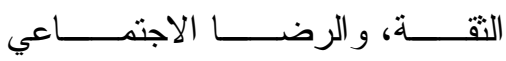

.( OECD.2019,Apr.10,3-4 )

○ـ - الطبقة الوسطى هـــي التـي ترفـع

معدلات النمو على حد قــول "جــون

كينز "John Keynes وليس العكس،

كما أن التقة هي التي نرفع معـدلات

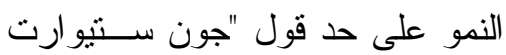


التحسن، وأيضاً يوجد نموذج آخر على ذلـــــ

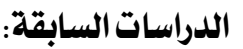

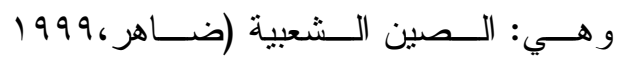

توصلت العديد من الدراسات السابقة

،9: • (1). فالكثافة السكانية تدخل في حسساب

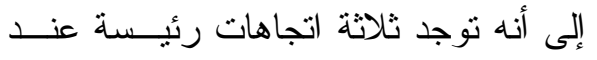

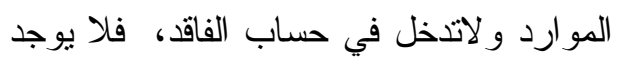

دراسة الطبقة الوسطى: الاتجاه الأول: أنها

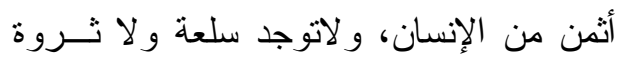

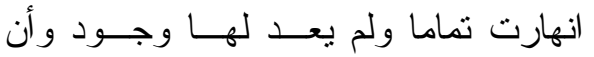

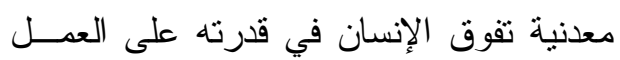

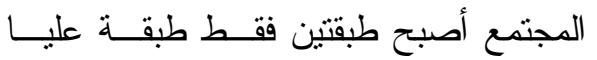

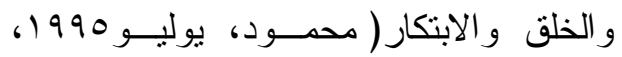

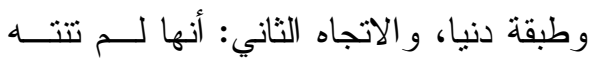
10). ومن المعلوم أن عدد الـسكان -الــذين

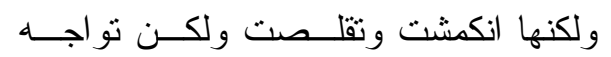

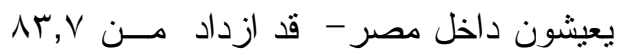
تحديات صعبة للغاية، و الاتجاه الثالث: أنها

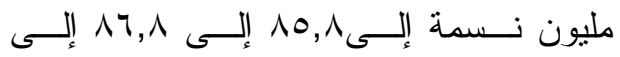
باقية وقادرة على تجديد نفسها بنفسها مهما

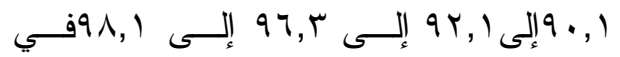
كانت العقبات و الصعوبات ومهمـــا كانــــ الأعو ام

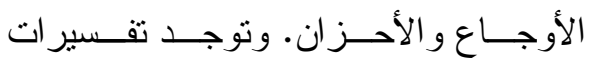
على التوالي ( الجهاز المركزي للتعبئة العامة

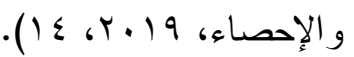
مختلفة لتلك الاتجاهات، من أبرزها الآتـي:

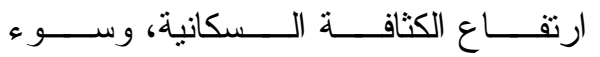
ولكن الإنسان الفرد لا يشكل قوة، ومن

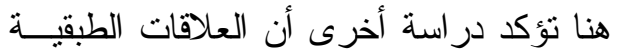

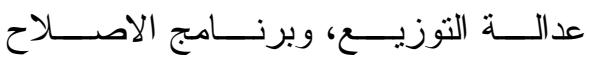
الاقتصادي المصري الــذي يعتبــر خطــــة في كافة المستويات هي في الحقيقة علاقـات اتحات

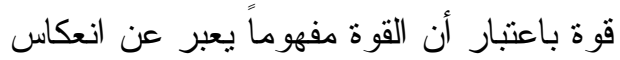
الأبنية الاجتماعية في مجموعهــا (ســليمان،

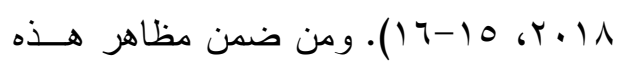

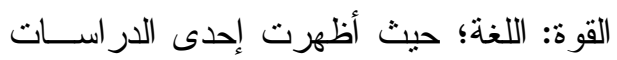

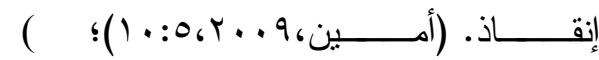
http://www.ara.reuters.Com,Aug. $.13,2019)$ وتثير الدر اسات السابقة إلى أن الفقر ليس سببه الكثافة السكانية العالية، و الـــليل على ذلك دولة اليابان فرغم قلة مسساحتها؛ حيث تبلغ تلث مسساحة مسـصر ، وكثافتهــا السكانية المرتفعة، وقلة مواردها الزر اعية

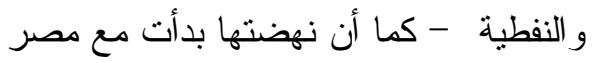
في ستينيات القرن الماضي- فإن معـدلات التتمية مرتفعة والمو اطن الياباني يشعر بهذا 


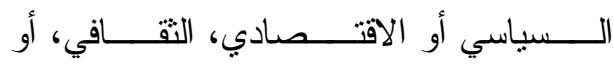
الاجتماعي؛ فقانون التعدد يتأكد هنا: استعمال

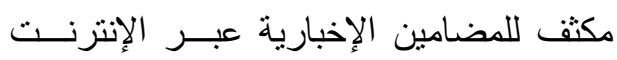
يرتبط باستهلاك قوى للمعلومــات الــصحفية

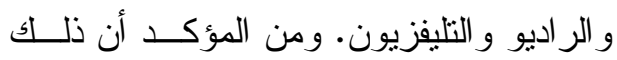

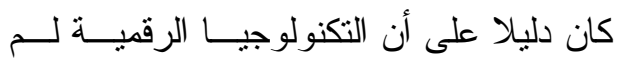
تقلص بتاتا الفو ارق الثقافية من حيث استهلاك

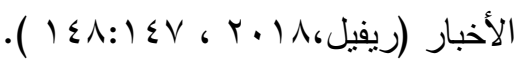

و إذا كانت اللغة مهمــة فــي تـسكين الأفر اد في طبقات المجتمع المختلفــة، فــان فـان

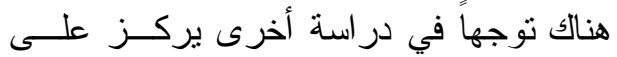

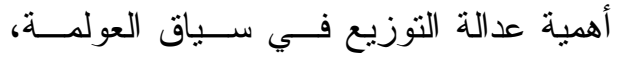
و النقطة الجوهرية التي يثيرها الاثـــتر اكيون

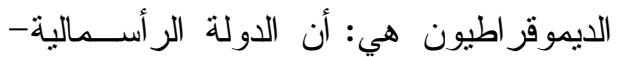

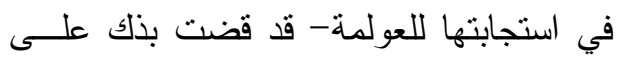

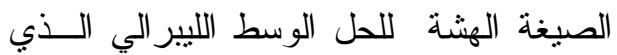
صيغ لتحديد العلاقة بين الدولــة و المجتمــع، و الذي سمح للرأسمالية بان تتوســـع داخليــا

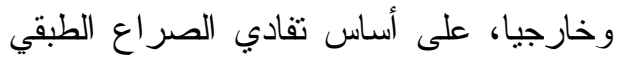

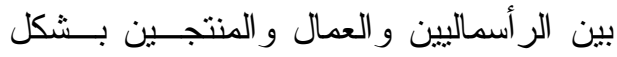

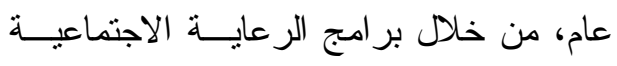
المتعددة. وبعبارة أخرى أصبحت ما يمكن أن تطلق عليها رأسمالية الرعاية الاجتماعية، أو

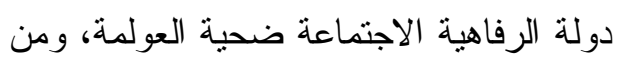

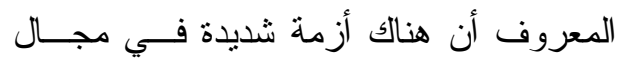

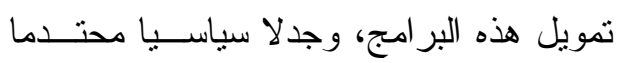

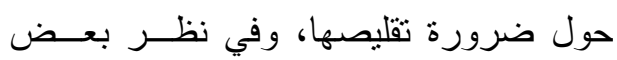

وتؤكد در اسة ثانية على أهمية اللغـــة فــي

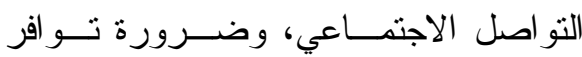

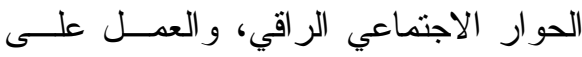
إبعاد الظلم الاجتماعي الذي يقع على الفرد و الجماعة و الطبقة، وضرورة تو افر الأمان

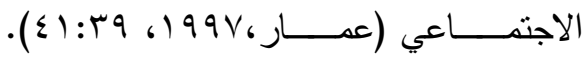

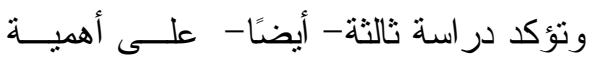
اللغة فــي اكتــساب المعرفــة، و الــسلطة السياسية من ناحية، ومــن ناحيــة أخــرى ولئه

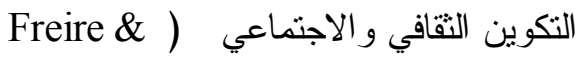
Macedo, 1987, 1:3 ) . وتؤكد در اســـة رابعة في هذا السياق على أهمية اللغة ونمط التفكير في تكون الهوية لدى الطبقة الوسطى لهي في إنجلترا (Reay, 2008, 1072:1088) و إذا كانت اللغة تــؤدي دور اً مهرً في تحديد الطبقات ، فإن القر اءة هي التـي

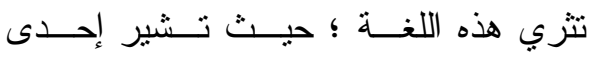
الار اسات إلى : أن أبناء الطبقـــات الفقيـــرة

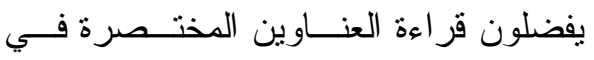

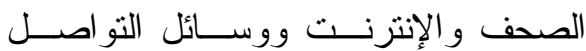
الاجتماعي التي لا تزكز على التحليل، بينما

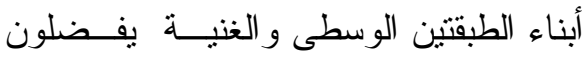

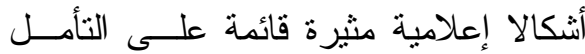

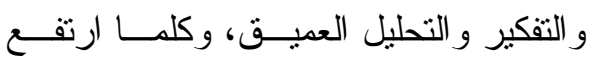

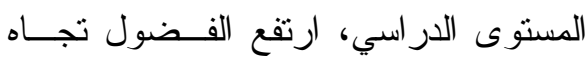

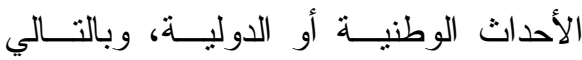
استعمال أكثر للويب خصوصا في المبــــان 
في مقابل اسقاط الضر ائب عن رجال الأعمال (كوبتشان، V)

وفي كوريا الجنوبية شـكـت الطبقــة

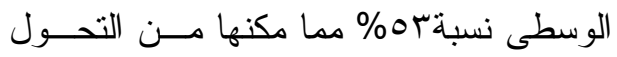
عن النمو في الــصادرات إلـــى الاســتهلالك المحلي ( Pezzini, 2019 ).

و إذا كانت اللغة، وعدالـــة التوزيــع،

ونمط اقتصاد السوق، و التحول من الصـادرات

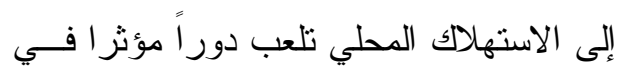

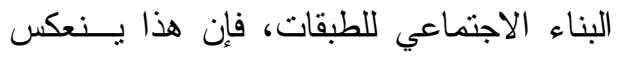

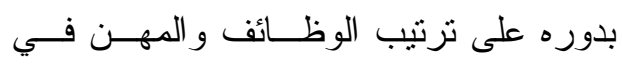
المجتمعات الختلفة

ففي كندا توصلت إحدى الدراسات إلى أسماء الوظائف العشر الأكثر شيوعا للفقر اء، و الطبقة الوسطى، و الأغنياء. فطبقة الأغنياء

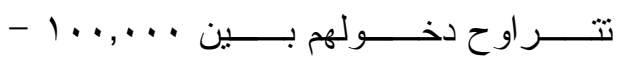

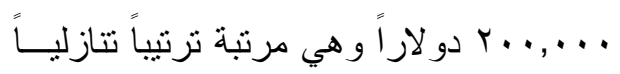

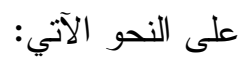
1- مديرو التسويق و الإعلان r- (المدير التنفيذي

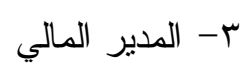
ع- متخصص تكنولوجيا المعلومات

$$
\begin{aligned}
& \text { 0- - المحاسب و المر اجع } \\
& \text { 7- الطبيب } \\
& \text { - V }
\end{aligned}
$$

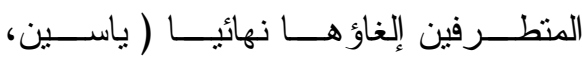

$$
.(1.1: 1 . .6) 999
$$

ومن هنا فقد نادت بعض الدر اســات

بضرورة تحويل اقتصاد السوق اللامركزية إلى اقتصاد السوق الر اديكالية حيث تتضاءل سلطة الدولة فيه دون أن تذبل، و الاعتمــاد على القرية أكثر من المدينة وهذا ما جعل " إلمهاتما غاندي " يقول: " لن أسمح بــأن تتتج المدن ما يمكن أن تتتجـــه القريــة "،

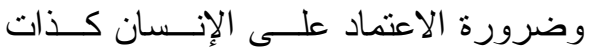
وليس على أنه موضو ع للاستغلال (و هبة، الاعنة . ( $\left.\wedge V_{6}\right) 999$

وفي معظم أنحاء أمريكا اللاتينيــة،

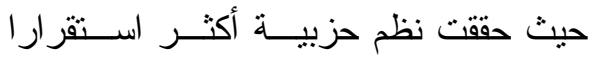
تسوية بين إقامة طبقة وســطى وحركــات

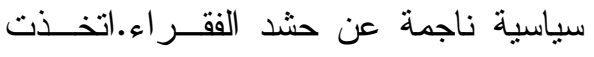
شعبوية الجناح اليساري شكلاً أكثر اعتدالاً ففي فنزويلا اتخذ الرئيس الفنزويلي "هوجو تشافيز" Hugo Chavez تأميم الــــنـاعات و الاعتماد على الــنفط و المعــادن و إعــادة توزيع الثروات لتحقيق لعدالة الاجتماعيــة.

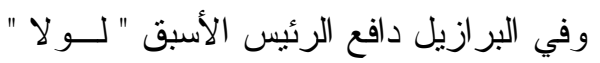

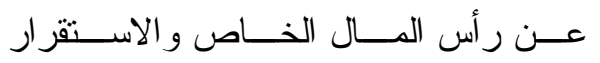
الاقتصادي الكلي و إعطاء أولياء الأمسـور

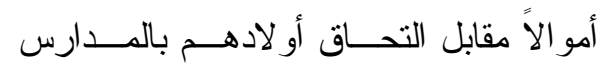

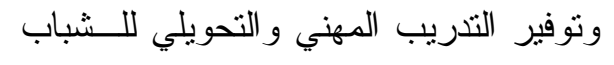




$$
\begin{aligned}
& \text { 7- مساعد التمريض } \\
& \text { - - مشرف المبيعات } \\
& \text { 1- سائق الثاحنة } \\
& 9 \text { - المعلم } \\
& \text { • }
\end{aligned}
$$

WWW. Careers.Workopolis.Com.30/8/2019(

$$
\begin{aligned}
& \text { وفــي أمريكــا، توجــــ · ( وظــائف }
\end{aligned}
$$

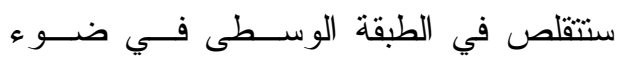

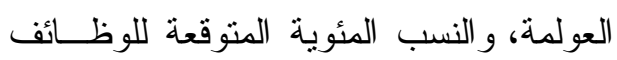

$$
\begin{aligned}
& \text { المفقودة جاءت على النحو الآتي: 1- ناشرو }
\end{aligned}
$$

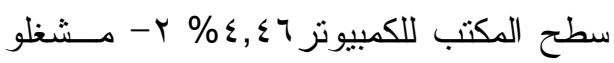

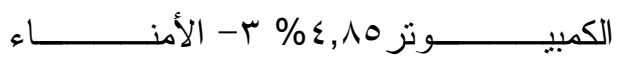

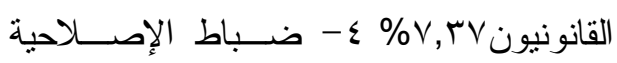

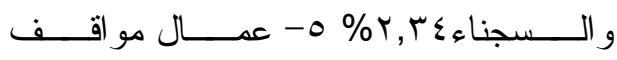

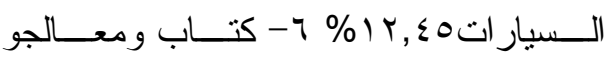

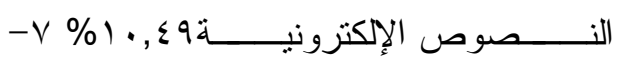

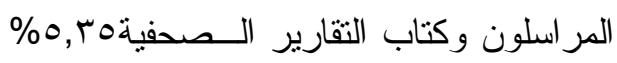

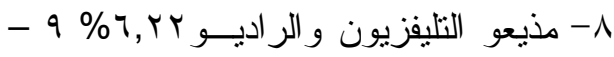

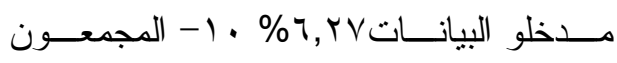

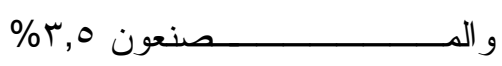

.(WWW.Bankrate.Com.30/8/2019)

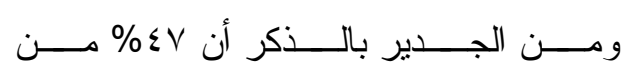

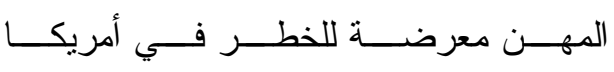

في ظل النطور التكنولوجي (Zaloom, ).

2018 )

$$
\text { ^- } 1 \text { - مندوبو المبيعات مطور البر امج }
$$

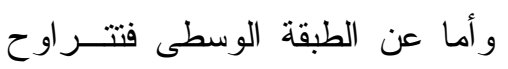

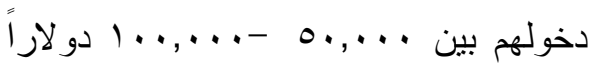
وهي مرتبة ترتيبا تتازليا على النحو الآتي:

1 - متخصص تكنولوجيا المعلومات

$$
\begin{aligned}
& \text { r- ضابط الثرطة } \\
& \text { r- مديرة مكتب } \\
& \text { ع- السكرثيرة } \\
& \text { ه- مطور البرامج } \\
& \text { צ- المحاسب } \\
& \text { V- سائق الثاحنة } \\
& \text { 1- المعلم } \\
& \text { 9- الممرضة } \\
& \text {. }
\end{aligned}
$$

وأما عن الطبقة الفقيـــرة فتتـــراوح

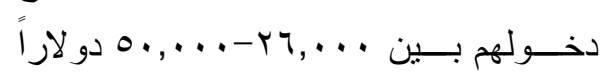

وهي مرنبة ترنيبا تتازليا على النحو الآتي:

$$
\begin{aligned}
& \text { 1- مدير المبيعات } \\
& \text { r- موظف الاستقبال } \\
& \text { ب- كاتب مبيعات التجزئة } \\
& \text { ـ- خدمة العملاء } \\
& \text { ه- - المديرون }
\end{aligned}
$$


التي تبنتها الدر اسة الحالية، و أقلهما اسـتـعمالًً هي الوسيطة وإن كانت علوم الإحصاء تهـتن

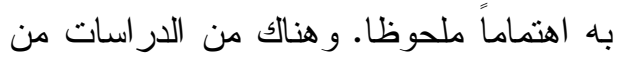

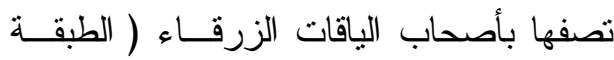

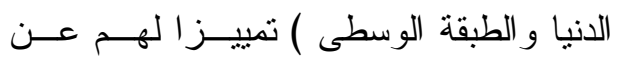
أصحاب الياقات البيضاء ويقصد بهم ( الطبقة

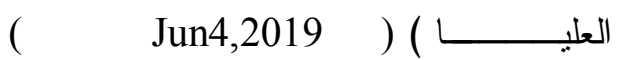
Frankenfield,2019، و هنـــاك در اســـات تصف الطبقة الوسطى بــأنهم مــن يحتلــون ون المنتصف على سلم التقدير الاجتماعي في أي لئن

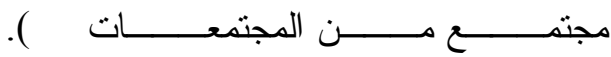
WWW.Investopedia.Com

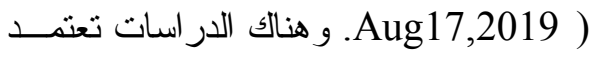

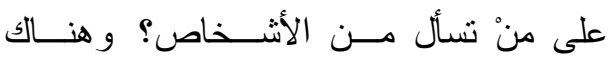
در اسات من تصفهم بــالحرفيين و المهنيـين كالطبيب، و المحامي، و الهــدرس . (WWW. Dictionary. Cambridge.Org. .Aug30, 2019)

لا يوجد تعريف جامع مـانع للطبقــة

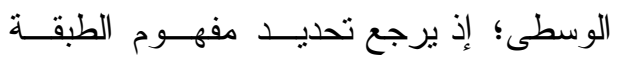
الوسطى إلى اختلاف الثقافات (18/8/2018 (http:/ en.m wikipedia.org على ذلك دراسة أخرى بأنه أذا أردنا تعريف

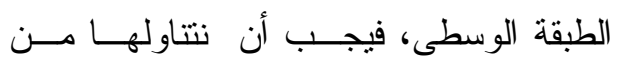

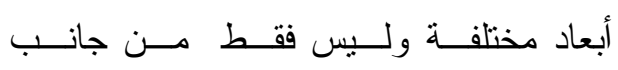

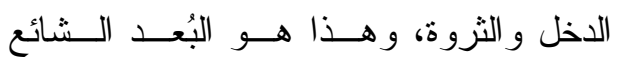

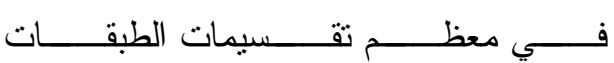

\section{يتضح مما سبق الآتي:}

- الكثافة السكانية العالية، لا تجلب الفقـــر

ولكنها قوى ناعمة تسهم فـي عمليــة

التنمية البشرية.

- تعاني الطبقة الوسطى في العـالم كلــهـ وليس في مصر فقط. - اللغة قوة، ويتجلى أبرز ملامح هذه القوة في الحوار بين طبقات المجتمع. - الصر اع الطبقي، قائم وقادم بقوة فــي ظل التفــاوت الطبقـــي الملحــوظ فـــي المجنمع - التحول الرقمي ( الرقمنة )، لن تـذيب

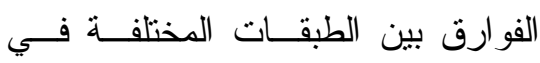
المجنمع. - التكنولوجيا، أدت إلمجتمعات إلى تغيير

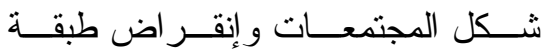

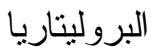

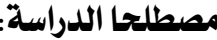

الطبقة الوسطى: Middle Class

هناك دراسات تطلق عليهـــــا الطبقـــة المنوسطة، و هناك أخرى تطلق عليها الطبقة

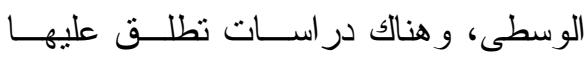

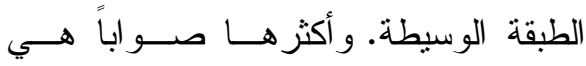

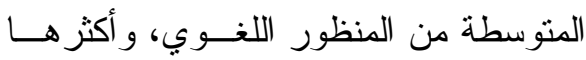
انتشاراً هي الوسطى من المنظور الإنسائي

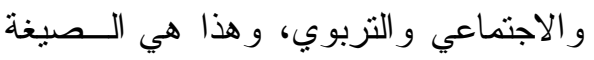


أسبوعين إجازة سنوية، وطفلان اثثان فقـط،

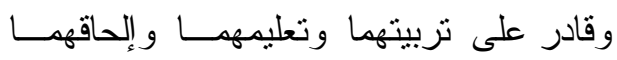

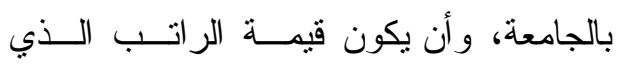

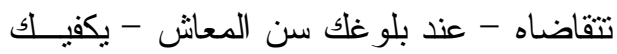

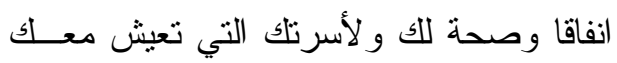
Institute for ؛(Mcwchinney, 2019) .(Research on Poverty, 2010 )

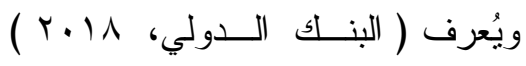
الطبقة الوسطى بأنها: هي التي تعيش علـى

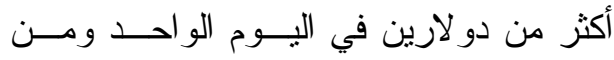

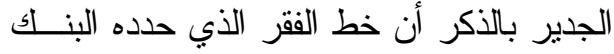

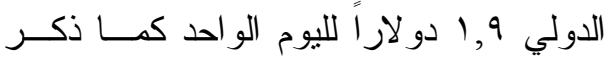

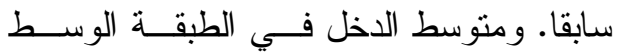

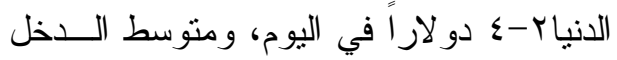

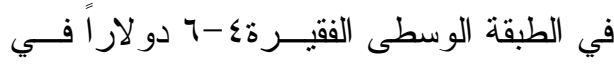

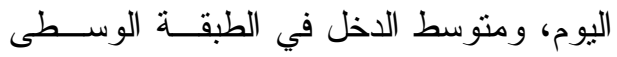

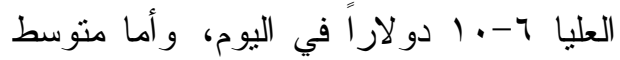

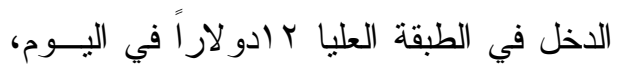
و أما متوسط الدخل في الطبقة الدنبا أو العاملة فيقل عن دولارين في اليوم الواحد Duflo) .\& Banerjeeat, 2008, 2:3)

ومن الجدير بالذكر أن هذه المتوسطات

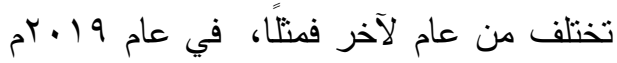
منوسط الدخل في الطبقة الوسطى الدنيا؟-. 1 دو لارًا في اليوم، ومتوسط الدخل في الطبقـــة

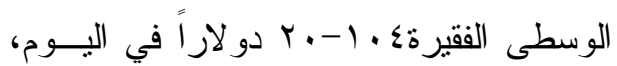
ومتوسط الدخل في الطبقة الوســـى العليــا
؛(Arkinson, \& Branolinig, 2011 )

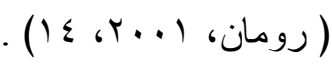

لذا توجد عدة تعريفات للطبقة الوسـطى؛

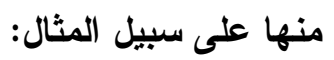

في ألمانيا يرى عالم الاجتماع "ماكس

فيبر" Max Weber إن الطبقة الوســـى

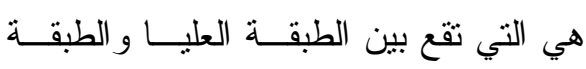
الدنبا، كما أن الطبقة تحدد بشر ائح وفئـات لهـئ

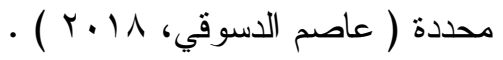

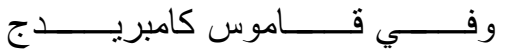

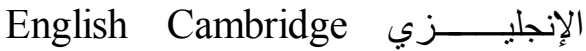
يُعرف الفرد الــذي ينتهــي Dictionary

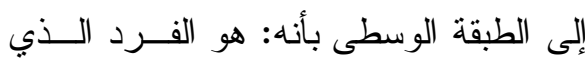
لايقع في طبقة الفقراء ( الطبقــة الـــنُنيا )

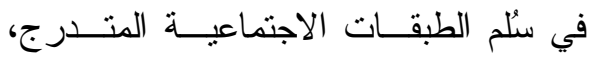

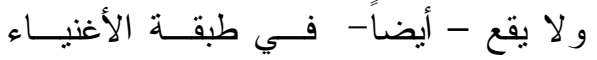

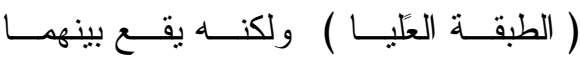
.(WWW. Dictionary.

Cambridge.Org. Aug30, 2019 وفي فرنسا- يوجد تعريف يشبه إلى حد كبير التعريف السابق إلى حد النطابق-

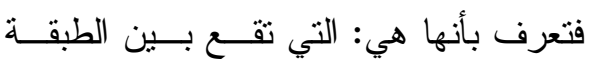

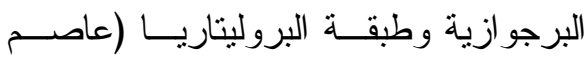

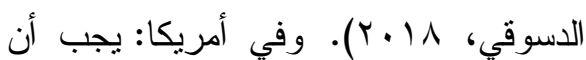
يكون لديك ستة خصائص لكي تتضم للطبقة

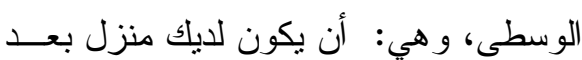

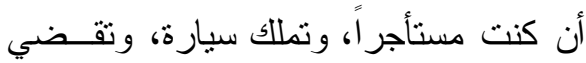


تحقيقه، وبُعده عن التهويــل و التهـــوين مــن

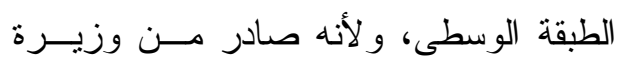

التضامن الاجتماعي الخبيرة في المجال.

الدور الاجتماعي: Social Role

وتعرف الدراسة الدور الاجتماعي بأنه هو:

الـــلـوكيات و الإجــــر اءات التربويــــة

المتوقعة من قبل الدولة، و ومنظمات المجتمع

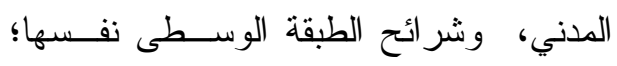

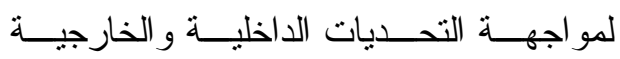

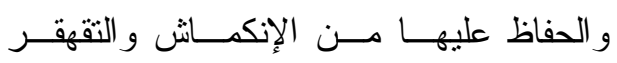
و الإنسحاب من المشهد الاجتمـــاعي وتـــــير مكان به أمن و أمان ويفتخر بــالعيش فيــهـ )

.Morneau, 2019 )

وقد ركز هذا التعريف علــى الأدوار

التي يجب أن تقوم بها الدولـــة، ومنظمـــات

المجتمع المدني، و الطبفة الوسطى نفسها هــــا

من ناحية، ومن ناحية أخرى تحديد التحديات

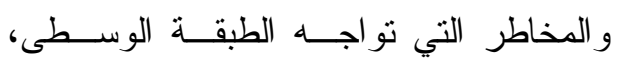

ووضع تصور مقترح لمو اجنتها.

خطوات الدرسة:

تتجلى خطــوات الاراســـة فــي المحســاور الآتية:

المحور الأول: إثــــالية مفهـــوم الطبقــة

$$
\text { الوسطي وتقسيماتها. }
$$

المحور الثـاني: تطورتـــاريخي للطبقـــة

$$
\text { الوسطي في مصر · }
$$

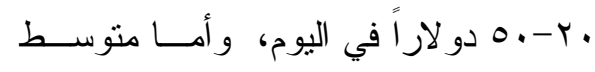

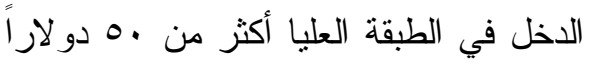

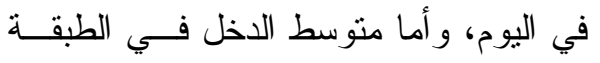
الدنيا أو لطبقة العاملة فيقل عن دولاريــن اثثين فقط في اليوم الواحد كما ذكر ســابقًا

( World Bank, 2019)

وهناك من يحدد الطبقـة الوســطي

بالقيمـــــة المطلقــــة Absolute Term وهي أكثر من دو لارين، وهناك من يحددها بـالقيم النـسبية: Relative Term وهي دولارين، وهني

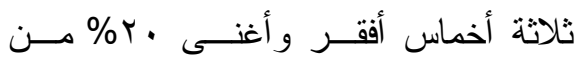

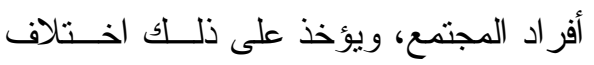

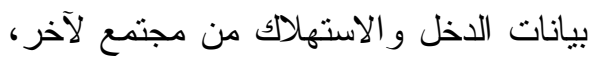

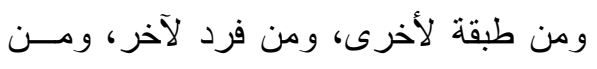

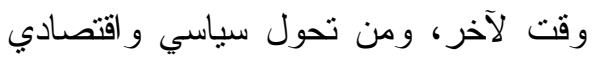

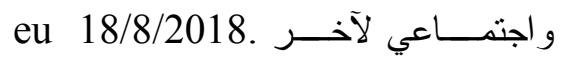
WWW. TheBrokeronline.

وفي مصر تُعرف الطبقة الوســطى مَّل

بأنها: مَنْ يجدون قوت يومهم؛ أبي أن دخلهم لوني

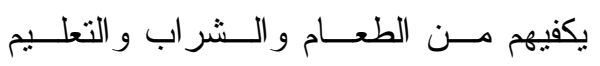
و الصحة؛ أي يكفـــهـم لأساســـات الحيــاة.

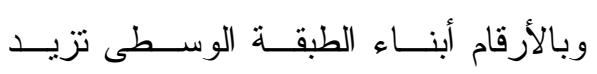

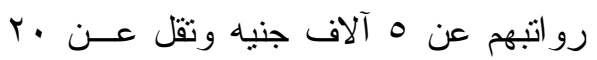

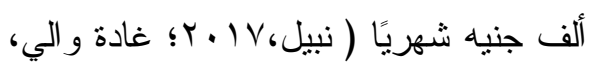
.$(r \cdot)$ وقد تبنى الباحسـث هـــا التعريـــ لو اقعيته، وبساطته، ووضــــوحه، و إمكانيـــة 
الحملة الفرنسية نحو مليونين ونصف، ويتميز بتكوين خاص، فلم يكن مجتمعًا مصريًا بحتًا، بل كان ينقسم إلى ثلاثة عناصر : عثــانيين،

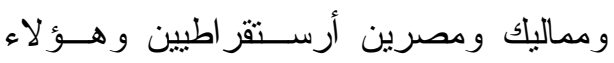
يمثلون الطبقة الأولى التي تتركز السلطة فــي وني

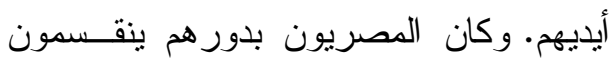
إلى بدو وحضر ، و إلى مسلمين و أقباط، و إلى لى بلى

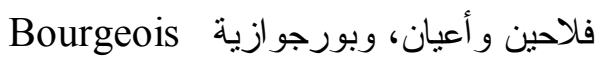

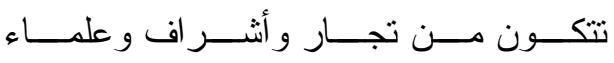
وحرفيين. و هؤلاء يمنلـــون الطبقـــة الثانيـــة محسـرومين مــن الــسلطة. وكـــان هنــاك

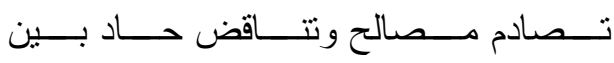

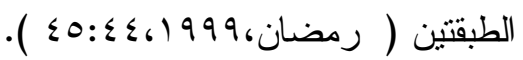

وبعد قدوم الحملـــة الفرنــسية بقيــادة

نابليون في نهاية القرن الثامن عشر و انهز امها

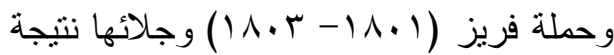
حركات مقاومة وثور ات شــعبية، وبعـــ أن

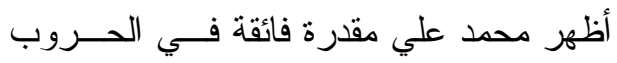
و القتال و الدفاع في جانب المــصريين جــاء

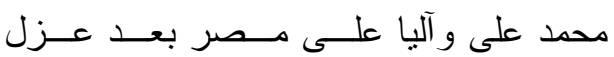
خورشيد بانشا. و عمل محمد علي على تكوين

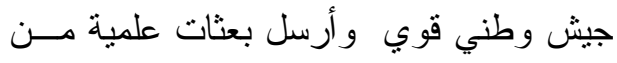

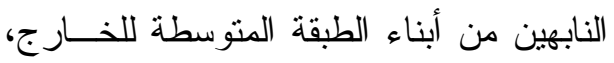
و اهتم بالتعليم لتكوين كو ادر إداريـــة لخدمـــة

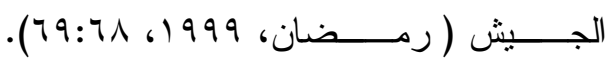
وكانت هذه بداية تكوين الطبقة الوسطى فـي ري
المحور الثالث: تحديد أهم أسباب انهيـار

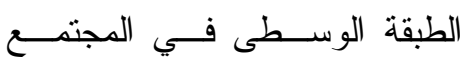
المصري.

المحور الرابع: وضع تــصور مقتــرح

لدور التربية فــي الحفــاظ علــى

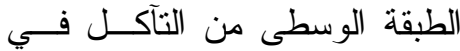
المجتمع المصري.

وفيما يلي نبذة مختصرة عن كل محور من المحاور السابقة

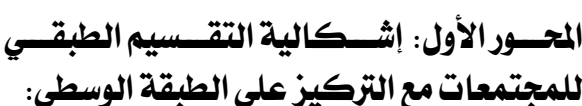
نشأة الطبقة الوسطى:

تشير إحدى الدر اسات إلى أن العـالم

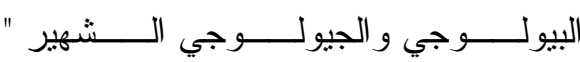
دارون " Darwin عندما نادى بمبدأ البقاء للأصلح Struggle for Survival، كـــان يقصد به الطبقة الوسطى، وهي أيضا الطبقة التي تعرضت للظلم الاقتصادي من ســوء وهي الهـ معاملة بعض رجال الكنيسة البروتـستانت

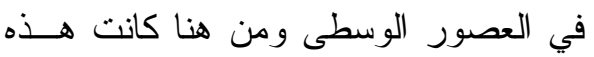
الطبقة هي وقود الثورة الفرنسية التي أثنعل

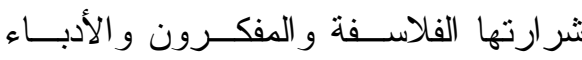
(I) TLان

(Tarkhnishvyil \& Tarkhnishvil, ؛ 2013, 2 )

وكان المجتمع المصري قبل الحملـــة

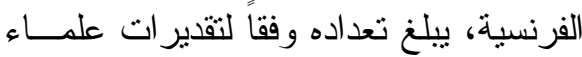


طبقتين فقط، ولكن التركيب المجتمعي يتكون مفهوم الطبقة الوسطى:

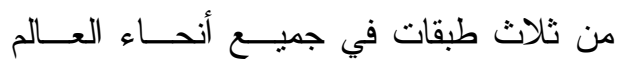

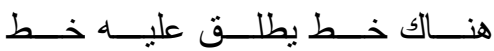

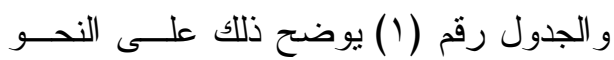

الفقر Poverty Line هو الذي يفرق بـين الأغنياء و الفقر اء، وكأن المجتمع يتكون من الآتي:

* جدول (1) نموذج للتركيب الطبقي الثلاثي للمجتمعات

\begin{tabular}{|c|c|c|c|}
\hline طبقة دنيا & طبقة وسطى & طبقة عليا & الدولة/العالم \\
\hline \%rт & $\% \circ 9$ & $\% 10$ & أمريكا \\
\hline$\% \backslash \wedge$ & $\% \vee r$ & $\% 1$. & ألمانيا \\
\hline$\% \backslash \leq$ & $\% \wedge$. & $\% \vee$ & الدانمرك \\
\hline$\% \leq \wedge$ & \%чr & $\% r$ & مصر \\
\hline$\% 11$ & $\% \vee \wedge$ & $\% 11$ & العال \\
\hline
\end{tabular}

* ت تركيب الجدول بمعرفة الباحث

WWW.TheBrokeronline.28Aug.2018 \&WWW.Investopedia. 25 Jun,2019 المصدر:

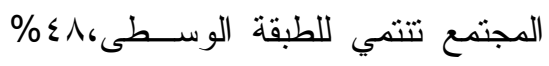

من المجتمع تتنمي للطبقة الدنيا.

- بمقارنة النسب المئوية للطبقــات فــي

مصر نظيرتها في الدول المتقدمة يلاحظ

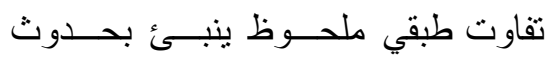

$$
\text { صر اعات و عنف وثثرة. }
$$

في ضوء ما سبق، يكــون التركيــب

الاجتماعي للطبقات في المجتمع السعيد الذي مني

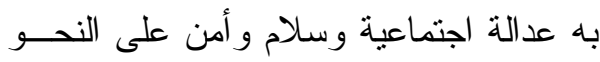

$$
\text { الآتي المبين في الجدول رقم (r) : }
$$

$$
\begin{aligned}
& \text { يتضح من الجدول السابق رقم (1) الآتي: } \\
& \text { - في الدول المتقدمة • 1\% في المتوســ }
\end{aligned}
$$

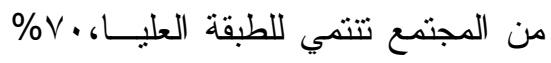

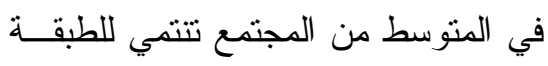

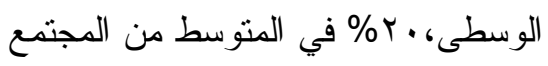

$$
\begin{aligned}
& \text { تتنمي للطبقة الدنيا. } \\
& \text { - - و العكس في مصر، حيث \% فقط من }
\end{aligned}
$$

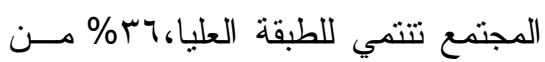




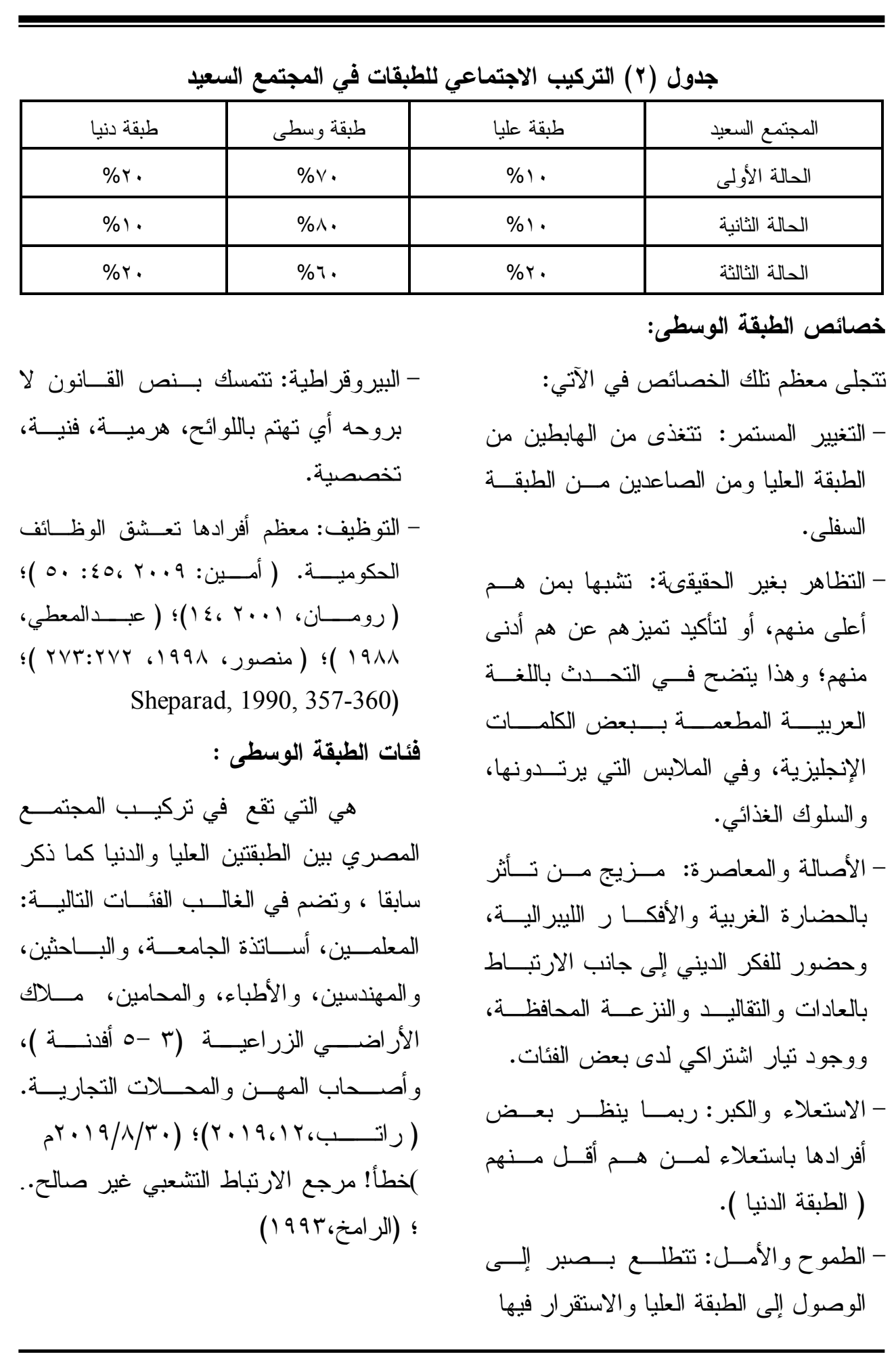


الأنصر اف عن "رع " وما يمنلكه من استبداد

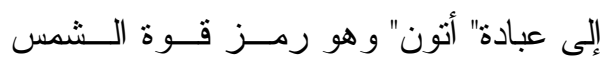
وضوئها وحر ارتها. أي أنه اتجه إلى تجريد الطبقة المستبدة من قدسيتها، وفصل الــدين

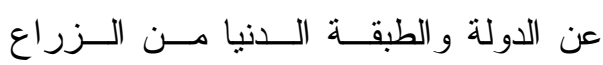

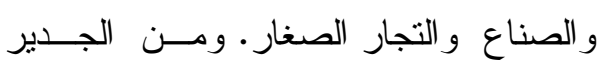
بالذكر كانت مهنة الكتابة من أثرف المهـن

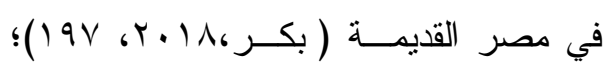

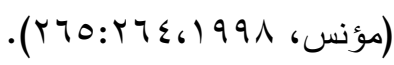
ولقد قسم أفلاطون المجتمع الأثثنـي على أساس عنصري إلى ثلاث طبقات: عُليا

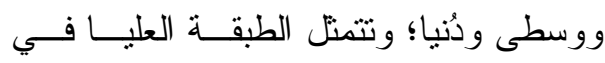

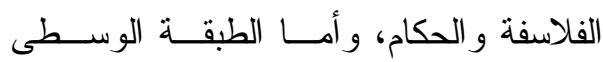

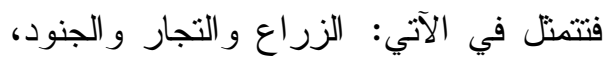

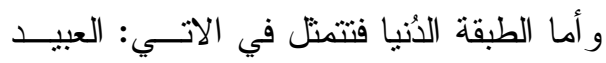
( خباز، 1910 )؛ (كـرم، (111، (11) ). و الجدول رقم (ץ) يوضح ذللك علــى النحــــ
ويتضح مما سبق، أن أغلب شــرائح

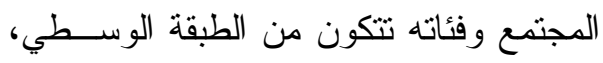
وسيرد تفصيل عن النسبة المئوية لهذا الطبقة في الدر اسة الحالية. تقسيمات الطبقة الوسطى: توجد عدة معـايير لتقـــيم طبقــات

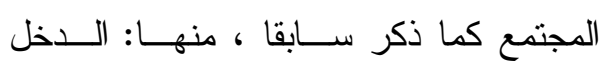

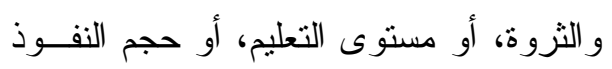

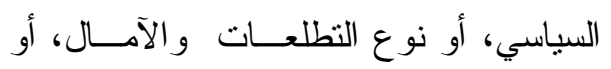

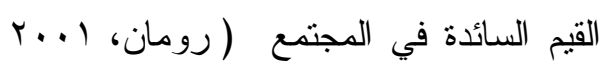

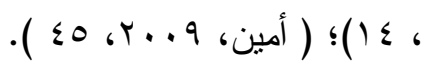
في مصر القديمة تم تقسيم المجتمـعـ إلى ثنلاث طبقات هي : طبقة الحكام (الحاكم الإله) وطبقة وسطى و هي الطبقة المسـتبدة من العسكريين - ومؤيديهم من كبار رجـال

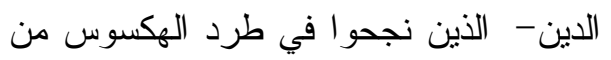

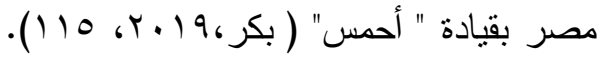

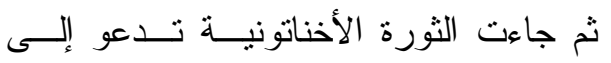

جدول (r) التركيب الطبقي الثلاثي في المجتمع الأثيني ووضعية الطبقة الوسطى )

\begin{tabular}{|c|c|c|c|c|c|c|}
\hline المعادن & نوع العمل & الفضيلة & جسم الإسسان & الفئات & الطبقة & 5 \\
\hline الذهب & التفكير و التأمل & العقل & الر أس & الفلاسفة و الحكام & عُلبا & -1 \\
\hline الفضة و النحاس & وخوض المعارك & الثجاعة & القلب & الزر العنو التجار & وسطى & $-r$ \\
\hline الحديد & الإلطساك عن شهوتي & العفة & البطن & العبيد & دُنيا & \\
\hline
\end{tabular}

* تم تركيب الجدول بمعرفة الباحث المصدر : خباز ، حنا (1910 ) . جمهورية أفلاطون، مترجم، بيروت -لبنان: دار القلم. 
سواسية كأسنان المشط لا فضل لعربي على اعلى

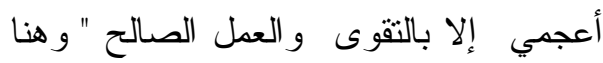

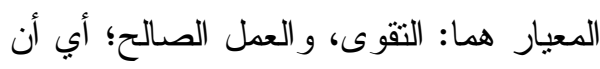

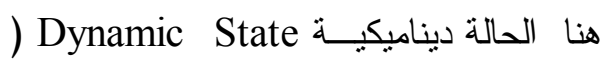

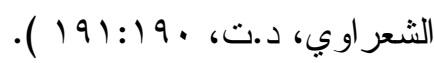

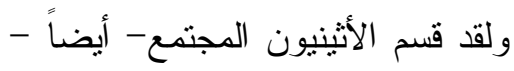

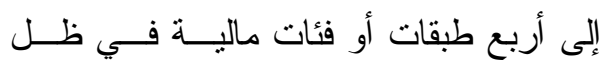

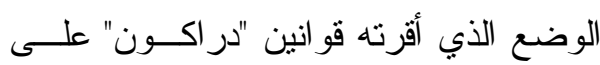
النحو الآتي:

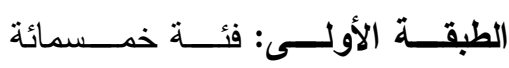

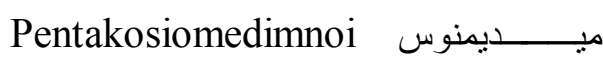
ويملكون أرضا أو عملا يحقق لهـم عائــدا

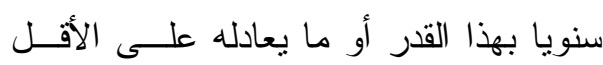
( الميديمومنون = كيل من القمح أو غيره) و هذه تعتبر طبقة عليا تتمتع بمناصب الحكم

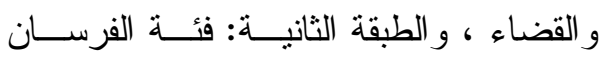
Hippies

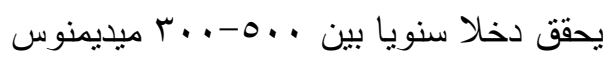

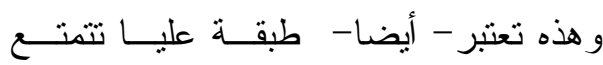
بمناصب الحُكم و القضاء ، و والطبقة الثالثــة:

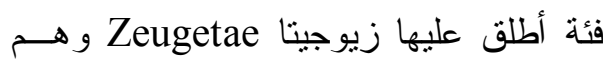

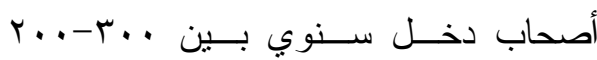

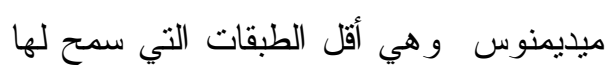

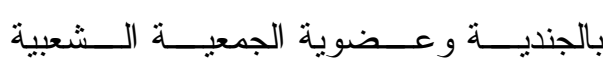

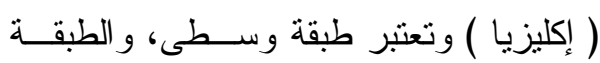

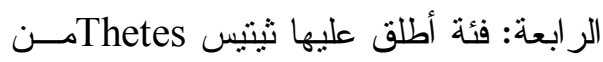

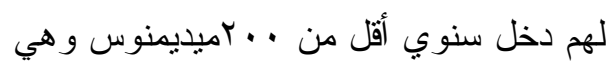

يتضح من الجدول السابق أن هنــاك

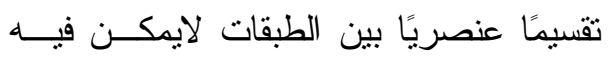

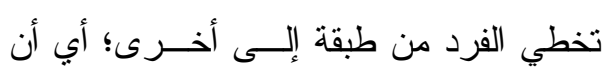

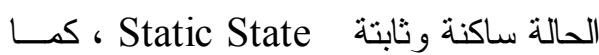

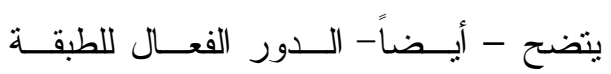
الوسطى. ومن الجدير بالذكر أن الدراســـة الحالية تعرض فقط هذا التركيب الطبقي من بن وجهة نظر أفلاطون الذي يعتدد على وجهة فئل

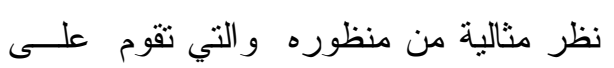

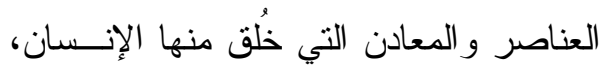

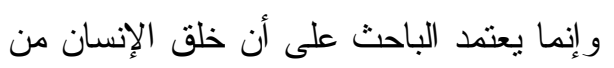
طين كما جاء في القر آن الكريم: " وَلَقَدْ خَلَقَّا

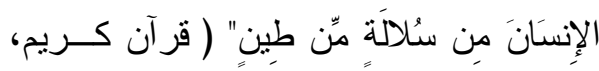
سورة المؤمنون، الآية:r (1). وقد أثبت العلم الحديث صدق هــذه

الآية ، فبالتحليل المعملي التجريبي أثنتوا أن العناصر المكونة للإنسان هي نفسها عناصر

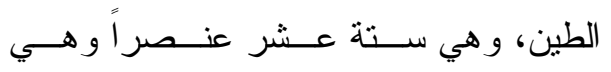
العناصر الصالحة للزر اعة؛ لأن الأرض بها عها

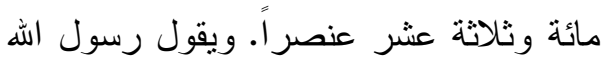
صلى الله عليه وسلم: " كلكم مسن آدم و آدم من نراب ويقول رب العزة في كتابه الكريم

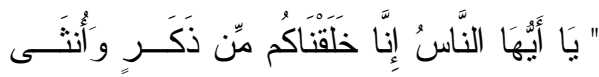

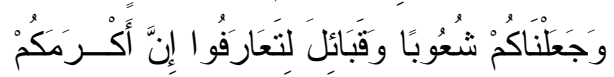

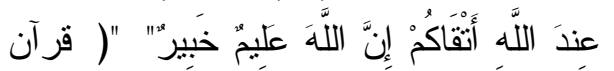

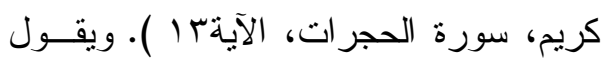

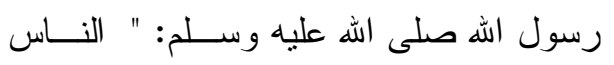


ولا قوام لهـــ جميعــا إلا بالتجــارة وذوي

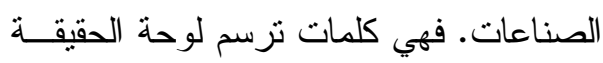
الاجتماعية لمــذهب الإســـلام الاجنمـــاعي:

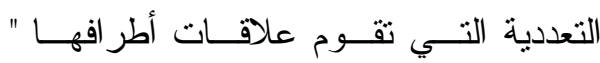
النو ازن" أي " التكافل الاجتماعي"، فلا قيــام

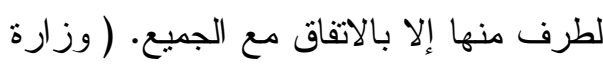
الأوقاف بالتعاون مع المجلس الأعلى للشئون

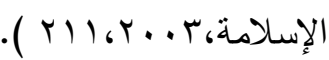

ولقد قسم "ابن خلدون" المجتمع على

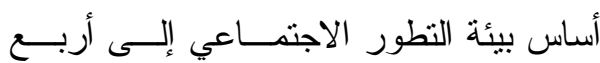

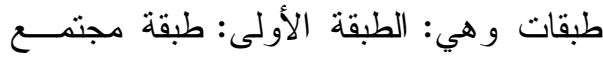
الصبد و الرعي، و الطبقـــة الثانيــة: طبقــــة

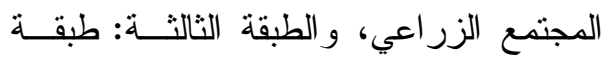

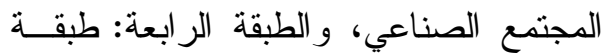
المجتمع الحضري. ومن الجديربالذكر أن هذه

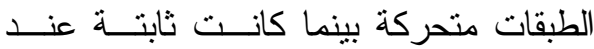

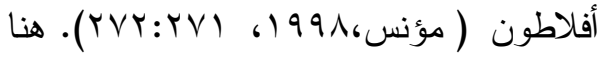

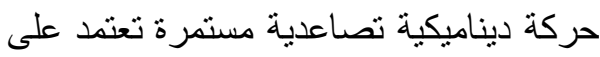
نفس الطبقة في التحول من مرحلة لأخرى.

ولقد قسم البنك الدولي World Bank

المجتمع على حسب الثـروة إلــى ثـلاث طبقات؛ وهي: طبقة المجتمع المتقدم، وطبقة

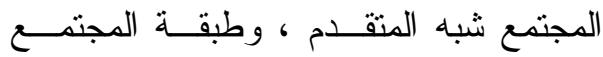

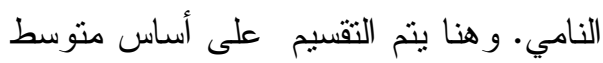
دخل الفرد بالدولار في هــــه المجتمعــات، وفي تلك الطبقـات المختلفــة فــي العــالم

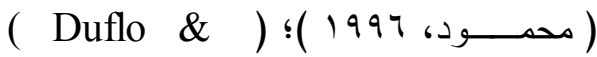

محرومة من الخدمة العسكرية ومحرومة من

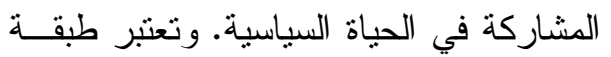

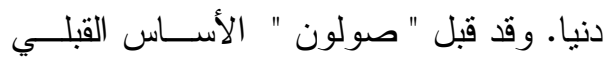

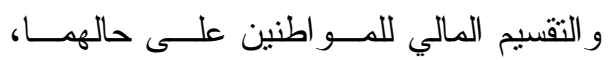
ولكنه تدخل بالتغيير و الإصلاح- في اتجـــاه ديموقر اطي و اضح- - وضع السياسي للطبقة

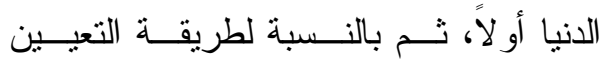
للمناصب المختلفة، على نحو يــضعف مــن

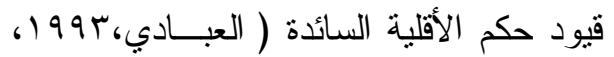
. $110: 0$ ). يتضح أن هذا النقـسيم مــادي

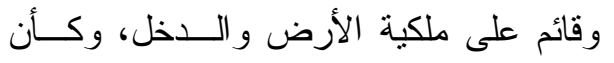
شعار المجتمع الأثيني: " من يملك يحكم ". ولقد قسم الإمام علي بن أبي طالــب

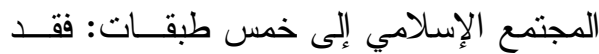

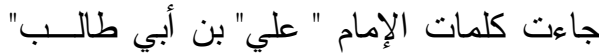
إلى و اليه على مصر " الأشتر النخعي" سنة فY

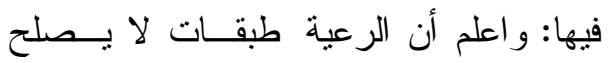

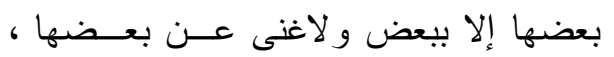
فمنها: طبقة جنود الله؛ فالجنود حصون مـن إلـن

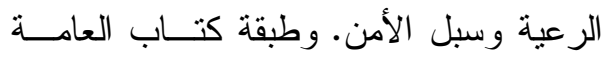
و الخاصة. وطبقة قضـاة العدل؛ ثم " لا قـــوام لهذين الطيقتيين السابقتين إلا بالطبقة الثالثـــة

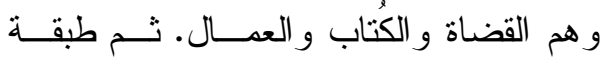
التجار و أهل الصناعات؛ ثم لا قو ام للجنــود وند

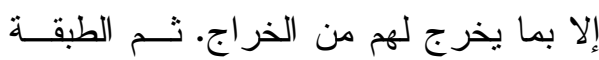

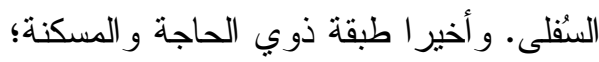


الصناعين مع الانقــلاب الــصناعي الــــي أحدثه في اقتصاد البلاد. وفي الوقت نفــــاه نشأت طبقة سادســة مــن " الإنتلجنت سئسيا " المثقفة ثقافة غربية، تفوق مثيلتها في أي بلد عربي، بفضل البعثات التعليمية التي أرسلت

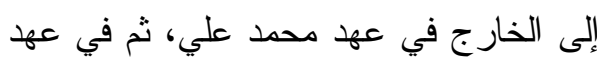
سعيد و إسماعيل، وبفضل المدارس الحديثــة

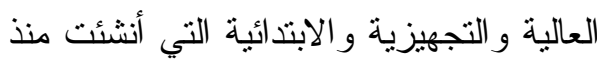
عهد محمد علي. وكان التعليم فـي جميــع المدارس بالمجان في عهد محمد علي، ولغير

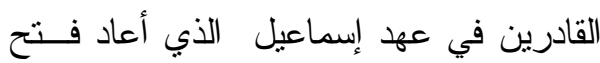

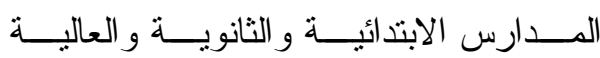
و العسكرية وبعض مدارس التعلــيم الفنـي. و إلى جانب هذه الطبقة التي تلقــــ العلـــوم الحديثة وبرز فيها الأدباء و الشعر اء ورجهـال

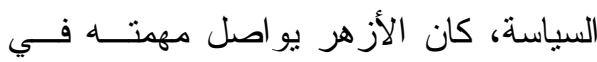

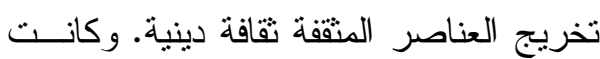

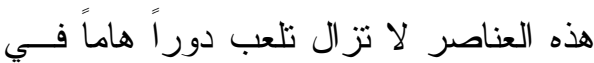

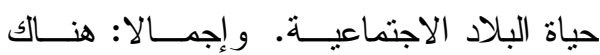
طبقتان رئيستان في عهد محمد علي هـــا: البرجو ازية ( من يملكــون ) و البروليتاريــا

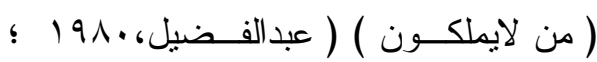

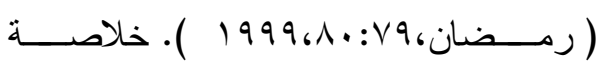
القول: إن محمد علي هو الذي أنشأ الطبقــة الوسطى في مصر ؛ حيث الهتم بتعليم أبنائها

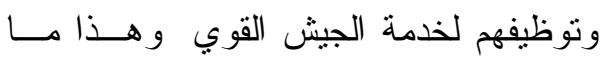

World ؛Banerjeeat, 2008, 2-3

( Bank, Pew research centre, 2019) ولقد قسم "نبيل على" المجتمع علــى حسب المعلومات إلى ست طبقات؛ وهـــي:

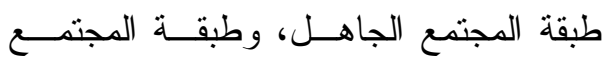
الأمي، وطبقة مجتمع البيانات، وطبقة مجتمع وطن

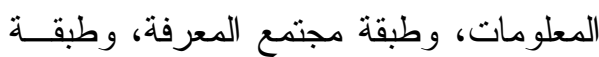

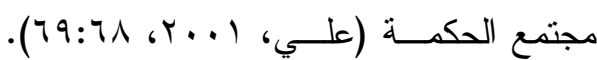
و هنا يتم التقسيم على أساس المعرفة؛ أي من يعرف ومن لا يعرف، ومن يعــرف أكثــر

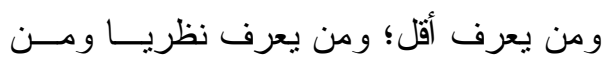
يعرف تطبيقا.

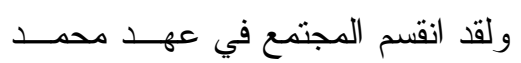
على إلى ست طبقات، و هي: الطبقة الأولى:

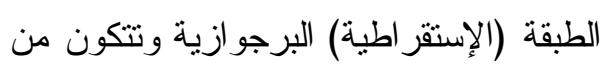
كبــار رجــال الإدارة و الجـــش و الأعيــان و الأعراب وأسرة محمد علي. الطبقة الثانية: طبقة الفلاحين وهي الطبقة التي انتقلت فيهـــا

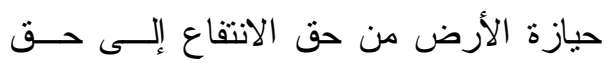
الملكية الخاصة (س-ه أفدنة). الطبقة الثالثة:

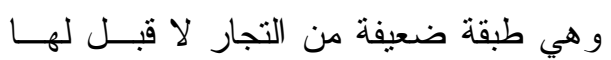

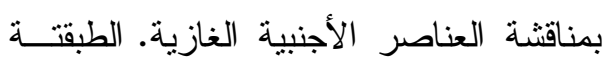
الر ابعة: وهي طبقة من الحرفيين منتشرة في

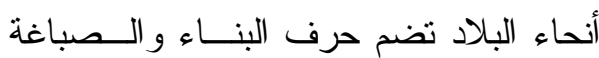

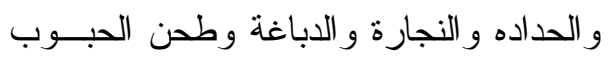
و غير ها وتتبع الأساليب القديمة في الصناعة. و الطبقة الخامسة: ظهــرت طبقــــة العهــال 
فرضت السلطات البريطانية رســوما عاليــة

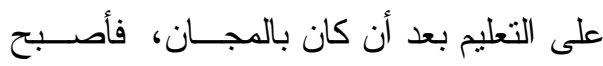

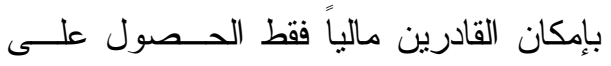
الخبرة المتميزة وذهب أولاد غير القــادرين

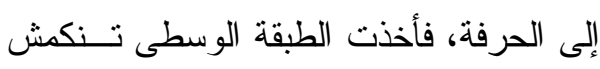

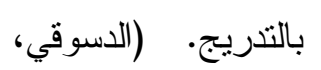

(http://www.alfikralarabi.org 14/8/2019

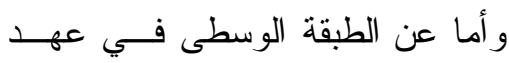

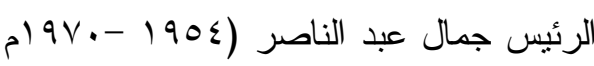

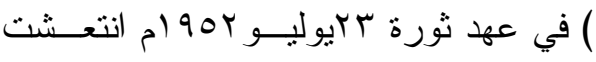

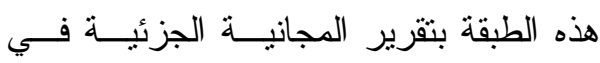

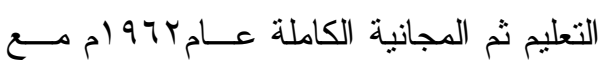
نشأة القطاع العام وسياسة توظيف الخريجين وبالتالي شعر هؤلاء المتعلمــون أو العمــال بالولاء للثورة، ومنهم جاء: معظم المهنيين

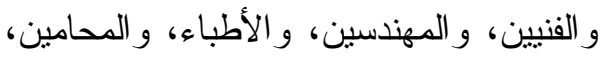

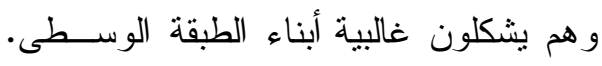

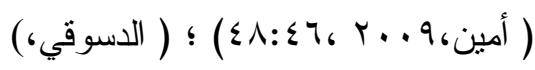
http://www.octobermageg.com 21/7/2018

ومنهم من قسم التزكيب الطبقي فـي

الريف في تلك الفترة إلى خمس فئات: طبقة

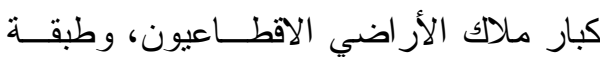

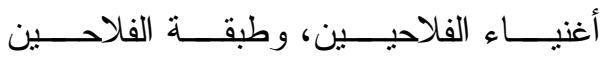
المتوسطين، وطبقة الفلاحين الفقراء، وطبقة العمال الزر اعين. ومنهم من قسم الطبقــات

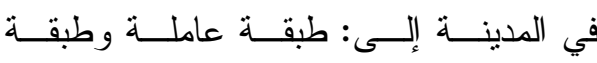
بورجو ازية و الني انقسمت إلى ثلاث شر ائح:
سيتضح في المحور الثـاني مــن الدراســة

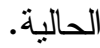

المحور الثاني: التطور التـاريخي للطبقـة الوسطي

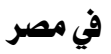
يتجلى هذا النطور في الطبقة الوسطى فـي الآتي: الطبقة الوسطى في عصر محمد علي

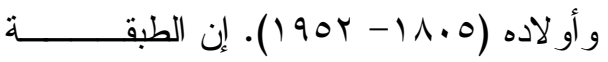
الوسطى في مصر نشأت من خـــلال نظــام

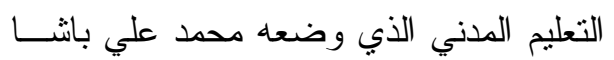
حيث كان يأخذ أولاد الفلاحين من النبهاء في المدرسة بالمجان وبعد انتهاء دراستهم تكون يأحن

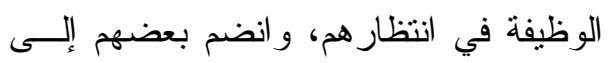
البعثات الخارجية زمن محمد على و الخديوي

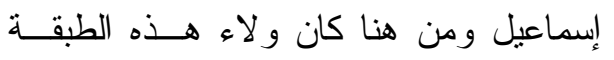

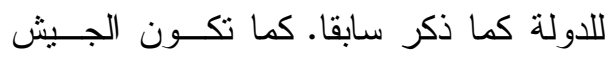

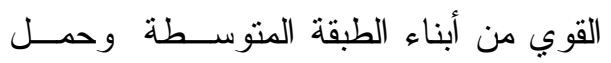
الفلاح الفأس تارة و السلاح تارة أخرى مــن

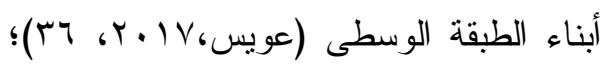

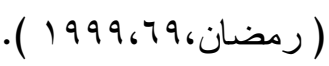
وإجمالا يمكن القول أن البناء الطبقي

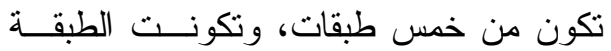

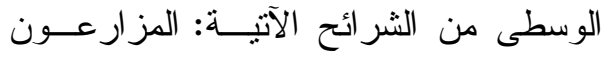

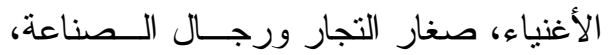
المثقفون، العسكريون ( الزيات، .99 (19). وأما عن الطبقة الوسطى فــي زمــن الاحتلال البريطاني (r 1919 - ع 190 )، فقد 


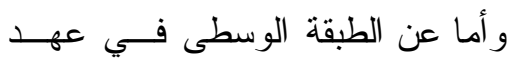

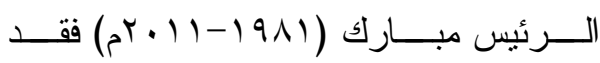

ارتقعت الطبقة الوسطى حتى وصلت إلـى على

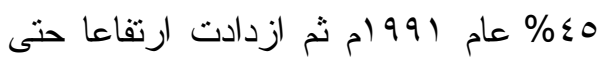

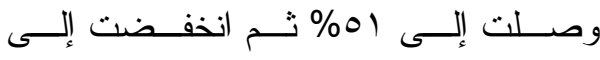

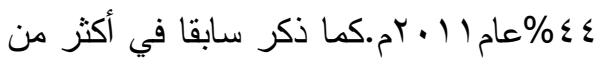

موضع في الدراسة الحالية. و أما عن الطبقة

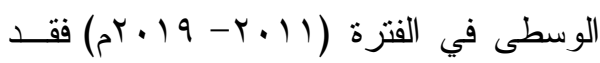

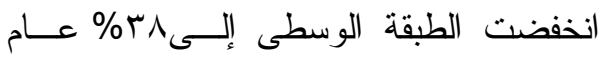

r I • rم و استمر الانخفاض حتى وصل إلـى

צr\% عام 17 ـابم (الجهاز المركزي للتعيئة

العامة والإحصاء، بحث الــدخل و الانفــاق

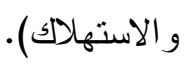

ويمكن رصــــ تآكــل الطبقــة فــي

مصرعلى النحو الآتي المبين في الجدول رقم

$:(\varepsilon)$
بورجوازية كبيرة، وبورجوازية منوســة،

$$
\text { وبورجوازية صغيرة ( حسنين، و } 9 \text { ( ). }
$$

و هنالك من قسم الطبقـــة البرجوازيــة

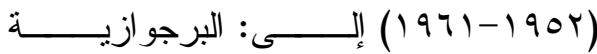

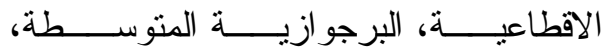

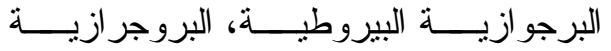

الصغيرة وفقر اء الفلاحين، و العمال و أثــــاه

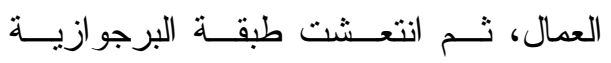

الصغيرة و انكشت باقي الطبقات البرجوازية

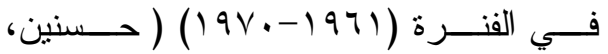

.$(191)$

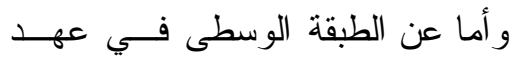

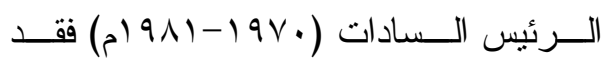

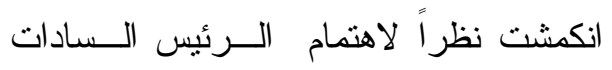

باقتصاديات السوق وقانون العرض والطلب و التحول من الاشــتر اكية إلــى الر أســــالية ولية

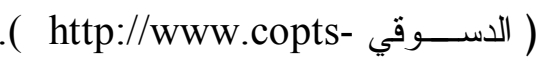

\begin{tabular}{|c|c|}
\hline النسبة المئوية & السنة \\
\hline$\% 19$ & 1900 \\
\hline$\%$ \% & $p^{1991}$ \\
\hline$\% 01$ & مr..o \\
\hline$\%$ \% & P.11 \\
\hline$\%$ \% & P.1r \\
\hline \% ru & 25.17 \\
\hline
\end{tabular}
united.com. 30/10/2010

* تم تركيب الجدول بمعرفة الباحث

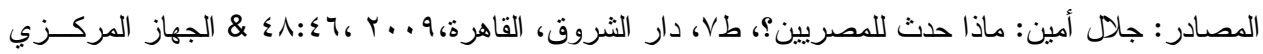

للتعيئة العامة و الإحصاء، بحث الدخل و الانفاق و الاستهلاك 


$$
\text { يتضح من الجدول السابق الآتي: }
$$

الثو ار : عيش، حرية، كر امة إنسانية، عدالـــة - تمنلت الطبقة المتوسطة بنسبة 9 1\% عــام

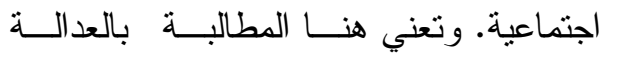

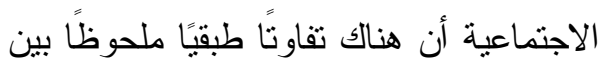

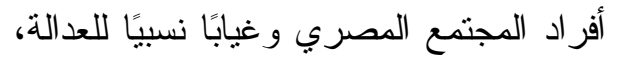

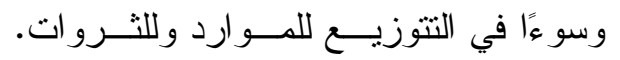

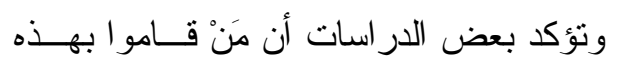

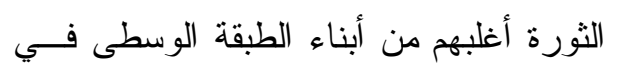

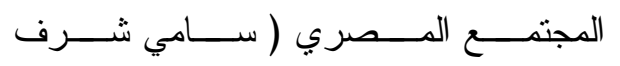
(1) 1 r. $1 \Lambda_{6}$

المحور الثالث: تحديد أهم أسباب انهيـار الطبقـة الوسطى في المجتمع المصري

تختلف أسباب انهيار الطبقة الوسطى في المجتمع المــصري بــاختلاف وجهــات

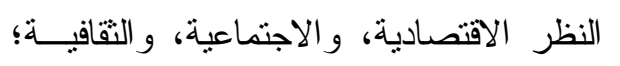

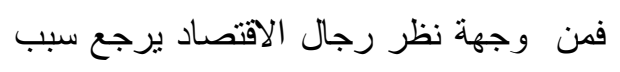

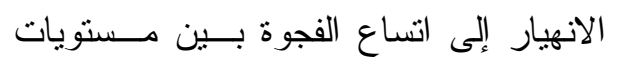
الدخول، و الجدول (†) يوضح ذللك:

900 ام و هو ما يمثل - تقريبــا- خُمسس الطس المجتمع المصري.

- ثم ازدادت نسبة الطبقة الوســـى حتـى

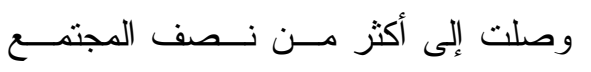

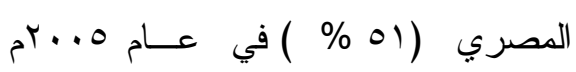

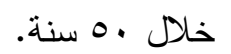
- ثم تتاقصت بشكل ملحوظ حتى وصلت إلى

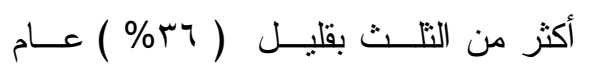

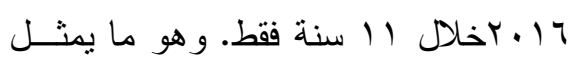
تهديدا وتحديا للمجتمع المصري.

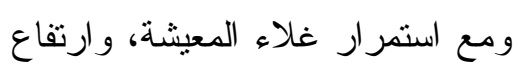
الأسعار ، وزيادة الكثافة السكانية من المنتظر

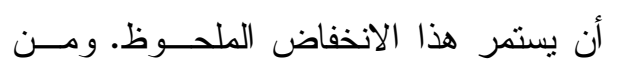

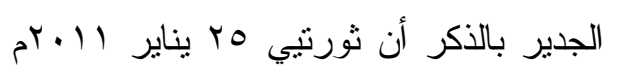

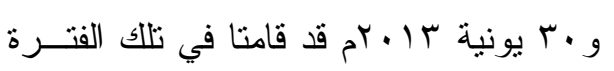

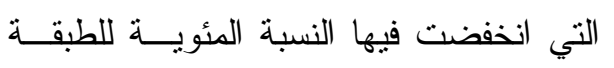

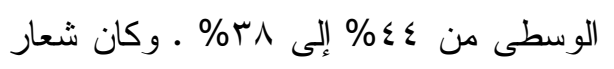

جدول(7) الحد الأدنى لأجور موظفي الدولة والهيئات الإقتصادية

\begin{tabular}{|c|c|c|}
\hline الحد الأدنى للأجور & الارجة & مسلسل \\
\hline V آلاف جنيه شهريا & الدرجة الممتازة & 1 \\
\hline ه آلاف جنيه شهريا & الدرجة العالية & $\bar{r}$ \\
\hline ع آلاف جنيه شهريا & درجة المدير العام & $\bar{r}$ \\
\hline 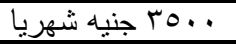 & الدرجة الأولى & $\varepsilon$ \\
\hline ال. r... جنيه شهريا & الدرجة الثانية & 0 \\
\hline . . TY جنيه شهريا & الدرجة الثالثة & 7 \\
\hline & الدرجة الر ابعة & $\bar{v}$ \\
\hline 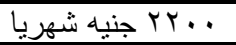 & الدرجة الخامسة & $\Lambda$ \\
\hline . F جنيه شهريا & الدرجة السادسة & 9 \\
\hline
\end{tabular}

المصدر : رئيس مجلس الوزراء المصري: قرار مجلس الوزر اء المصري الخاص بالحد الأنىى للأجور، أول يوليو 9 أبم. 


$$
\text { ويتضح من الجدول السابق الآتي: }
$$

و العالية طبقة وسطى نـسبيًا، وتعتبـــر

الدرجة الممتازة و العالية طبقة عليا.

- التفاوت الو اضح بين الأجور في جميـع

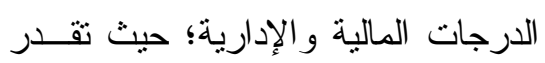

- ويفسر المثقفون ذلك: التدهور في مكانة

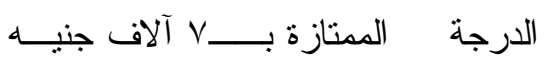

اللغة العربية، وتدهور محتوى التعلــيم،

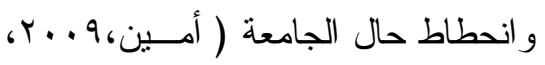

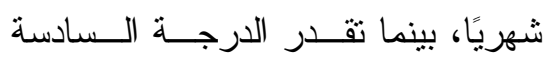

ب.... . بنيه شهريا فقط.

$$
\cdot(1): 9
$$

- تعتبر الدرجات من الأولى إلى الــسادسة

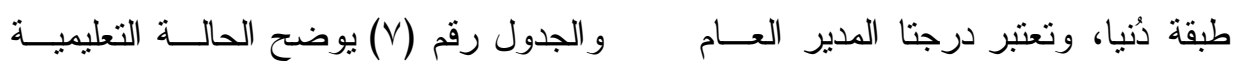

\begin{tabular}{|c|c|c|}
\hline النسبة المئوية & الحالة التعليمية & مسلسل \\
\hline \%r,lr & الأمي & 1 \\
\hline$\% 4.10$ & يقر أويكتب & r \\
\hline$\% r_{6} 10$ & شهادة محو الأمية & $r$ \\
\hline$\% v_{6} 10$ & شهادة أقل من المنوسط & $\varepsilon$ \\
\hline$\left.\% v_{6}\right) \leq$ & شهادة منوسطة & 0 \\
\hline \%r, \ᄉ & شهادة فوق متوسط & 7 \\
\hline
\end{tabular}
للطبقة الوسطى على النحو الآتي:

المصدر : فاطمة سيد أحمد: بالأرقام: كيف يعيش المعدمون والأثرياء في مصر ؟، مجلة روز اليوسف الأسبو عبة، أول

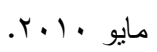

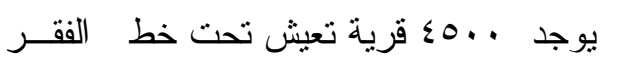

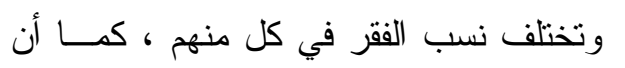

ومن وجهة نظر علمــاء الاجتمــاع

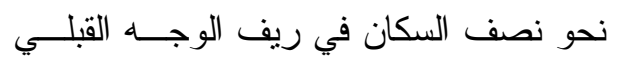

برجع ذلك إلى تدهور نمط الحياة في المدينة

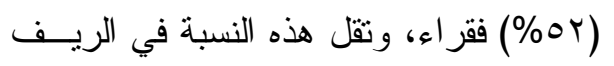

و القرية على السواء: المدينة تــزداد تلوثًا لـــا

و الذي يعيش فيه Vor\% من السكان.

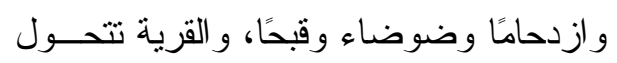

من قرية منتجة إلى قرية مسستهلكة؛ حيــ 


\begin{tabular}{|c|c|}
\hline 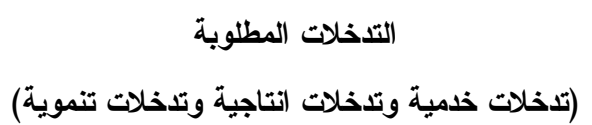 & للفقر في القزي المصبرية المئوية \\
\hline هي القرى الأكثر فقر اً و الأكثر تعرضـاً للتطرف & 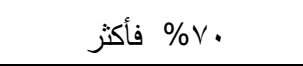 \\
\hline تحتاج للتنخل ولكنها أقل صعوبة & $\% \vee \cdot-0$ \\
\hline تو اجه تحديات وتحتاج تذخلات مباثرة & 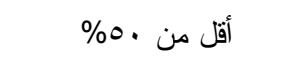 \\
\hline
\end{tabular}

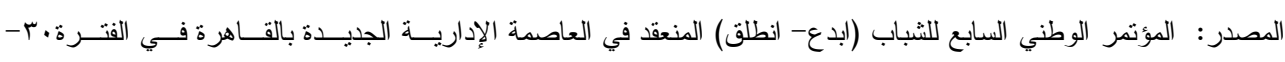

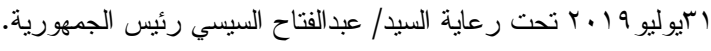

معدل البطالة في الفئة العمريـــة (1)

6

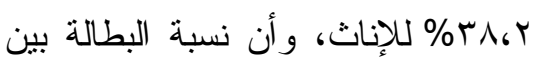

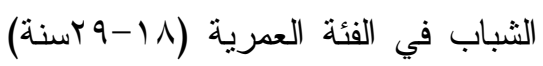
للحاصلين على مؤهل جامعي فأعلى هي

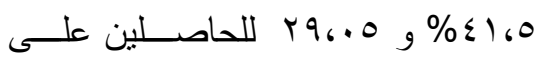
مؤ هل متوسط فني ( الجبـــالي، 9 1 ـ ب، .$(1)$

- إن متوسط خط الفقر، ومتوسط الـــخل الثهري للفرد، ومتوسط دخل الأســرة السنوي يتضنح من الجــدول (9) علــى النحو الآتي:
وفي مصر يفــل أوليــاء الأمسـور العيش في المناطق الحضرية عن العيش في المناطق الريفية و إلحاق أبنائهم بها، بينما في الولايات المتحدة الأمريكية يفــضل أوليـــاء الأمور من الطبقة الوسطى و العليا العيش في ليش المناطق الحضرية، بينما يرســلون أبنـــاءهم

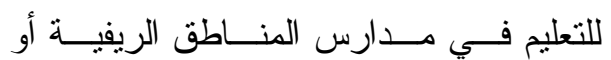
المجاورة للمناطق الحــضرية أو المــدارس الخاصة مما بـسـبب مــشكلات كثيـرة ) Posey, Kimelberg, \& Cucchiara, 2 014) - إن نسبة المصريين الذين يعيشون تحت

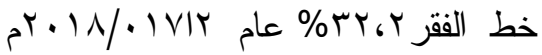
كما ذكر سابقا، وأن محتوى هذه النسبة من شباب الطبقة الوسطى العاطل، وأن 


\begin{tabular}{|c|c|c|c|}
\hline \multicolumn{4}{|c|}{ جدول (9) متوسطات خط الفقروالاخل الشهري للقرد و دخل الأسرة السنوي } \\
\hline متوسط دخل الأسرة سنويا & متوسط دخل الفرد شهريا & متوسط خط الفقر & البيان \\
\hline 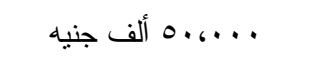 & أرآ جنيه & 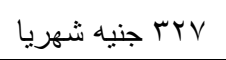 & $r \cdot 10 / r \cdot 1 \leq$ \\
\hline 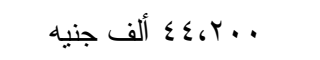 & 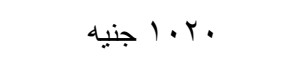 & 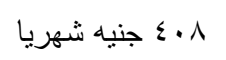 & $r \cdot 1 T / r \cdot 10$ \\
\hline ..... . 10 ألف جنيه & 171 جإ & وبا جنيها شهريا & $r \cdot I V / r \cdot 1 T$ \\
\hline . . . . . & 7rییזجنيه & ا & $r \cdot 1 \Lambda / r \cdot 1 V$ \\
\hline
\end{tabular}

المصدر : ( الجهاز المركزي للتعبئة العامة و الإحصاء، بحث الدخل والإنفاق)

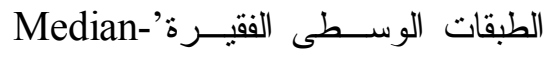
middle Class الاقتصادية الجديدة إلى النقص الحاد في

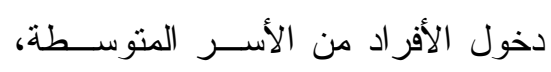

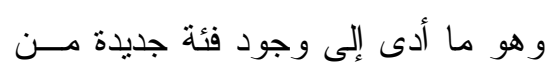

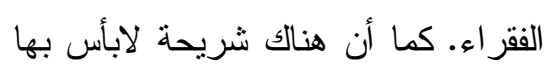
تقع فوق خط الفقر مباشرة، أي الطبقة الوسطى العاملة Working- Middle Class Lower- Middle Class حساسية لأي نقلبات تحدث في الأسعار

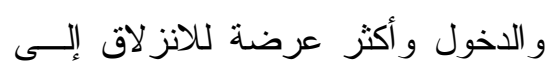

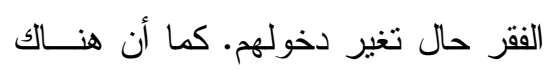
طبقة وسطى أخرى تتطلع إلى الإنضمام للطبقة العليا وهي مؤهلة لــذلك نفـــيًا

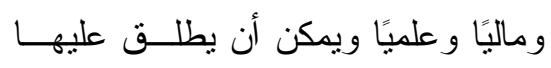
Upper- Middle الطبقة الوسطى العليا وعليا ونكان

$$
\text { Class }
$$

$$
\text { يتضح من الجدول السابق الآتي: }
$$

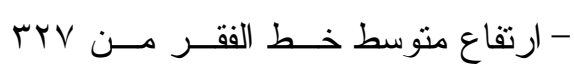

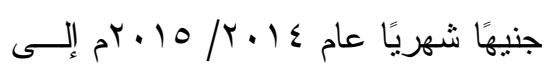

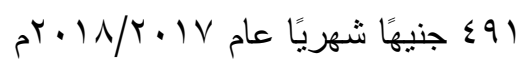

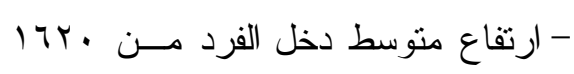

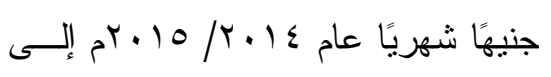

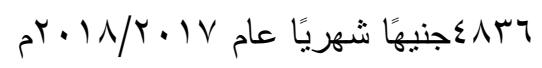

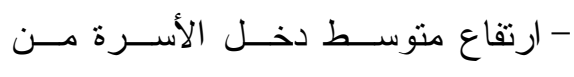

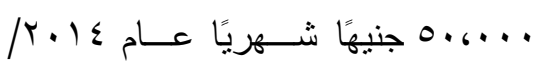

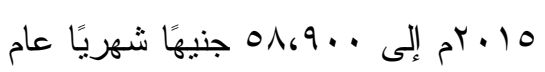

$$
\text { r. } 11 / r \cdot 1 \mathrm{r}
$$

ورغم ارتقاع مستوى دخــل الفــــد

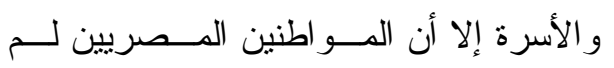
بحسو ا بهذا التحسن النسبي؛ وذلك يرجع إلى الى

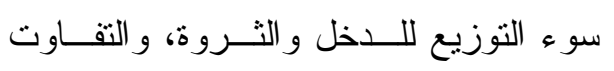

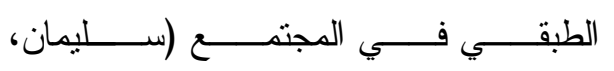
(I) (1) I) r. IA - إن النطور ات الحديثة النــي أدت إلـى

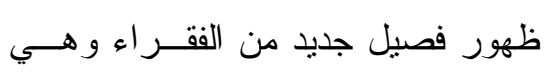


التغيب عن المدرسة، وعدم الانتظــام فـي

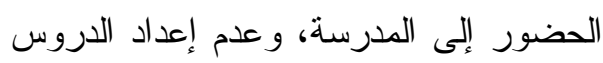

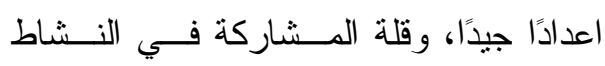
الصفي، و عدم الرغبة في حضور الــدورات

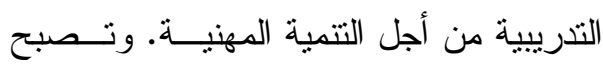

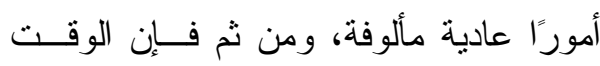
و الطاقة اللذين تتطلبها مهام المجتمع يصبحان

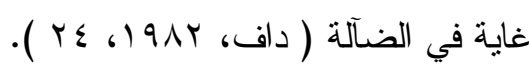
ولماذا لاينجح الباحثون و العلماء مسن أبناء الطبقة الوسطى في آداء مهـــامهم فـي لوني مصر ؟ ويتجلى أبرز ملامح ذلك في الآتـي:

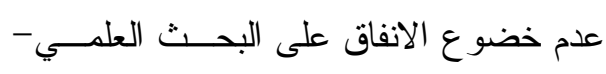
رغم ضعفه- لتزشيد معقول، وبيروقر اطيـــة

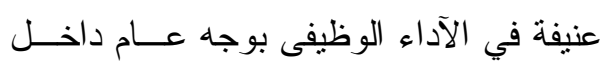

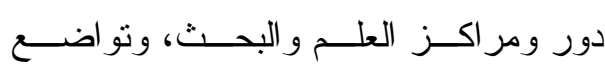
احساسنا في مصر بدور العلم و التكنولوجيــا

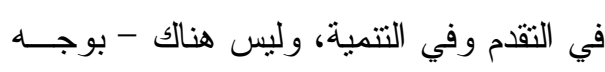

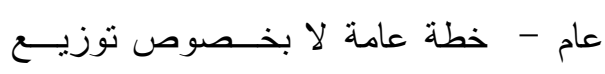

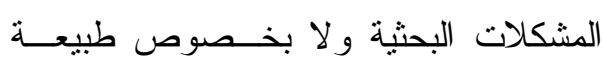

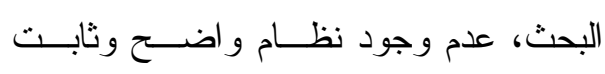

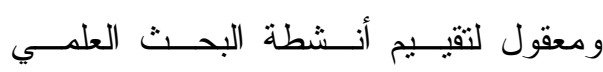

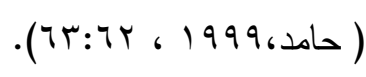

و لمـــاذا لا يــنـجح أبنــــاء الطبقـــات الوسطى بوجه عام في الداخل، بينما يكــون

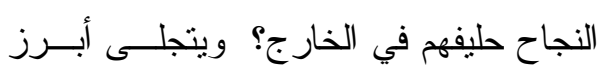

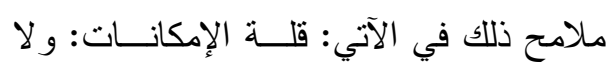

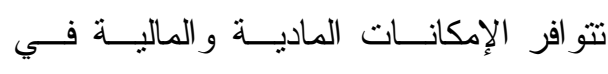

ومن هنـــــا يلاحـــ انقـسام الطبقــة

الوسطى نفسها إلى ثناث طبقات أو شر ائح:

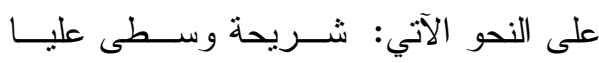
( برجوازية كبيرة ) ، شريحة وسطى فقيرة النية

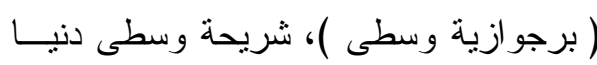
( برجو ازية صغيرة ) (عبد الفضيل، • 91 (1). ويتضح مما سبق أن الطبقة الوسطى

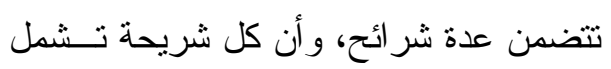
عدة فئات مهنية وتلقي دائرة الفقر بظلالها على جميع

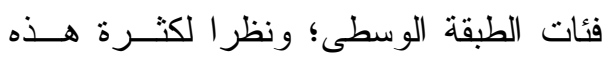

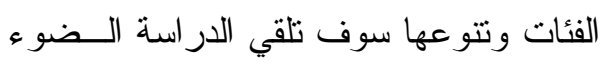

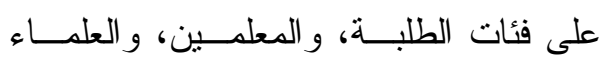

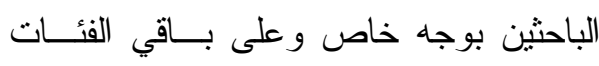
الأخرى بوجه عام على النحو الآتي: لماذا لا ينجح المعلمــون مــن أبنــاء

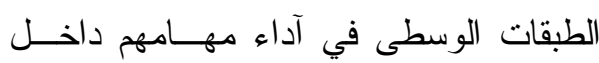

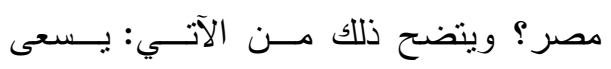

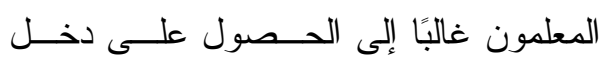

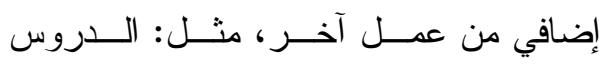
الخصوصية، امتلاك قطعة أرض صــنيرة

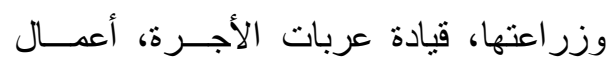

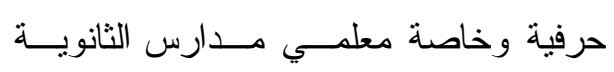

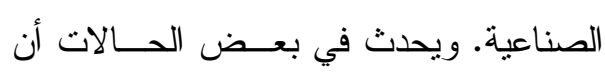

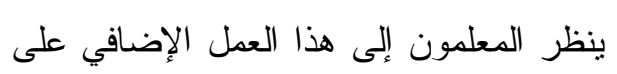

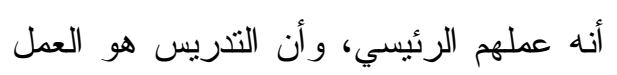
الإضافي. وينتج عن ذلك الآتـي: ظـــــاهرة 
لماذا يفضل أولياء الأمور من الطبقة

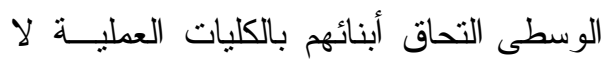
الكليات النظرية، بينما يفضل أبناء الطبقات

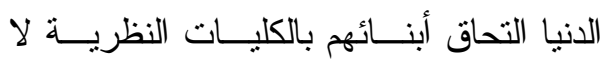
العملية؟ إن تكلفة التعليم الجامعي في الكليات

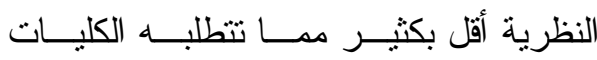

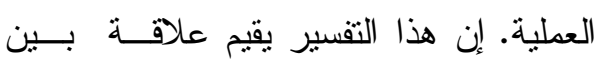

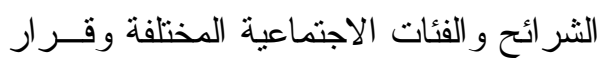
الاختيار بين القسمين الأدبي و العلمـي. و إذا صح هذا التفسير ، فإن الثر ائح الأقل مقــدرة و الأكثر فقر ا سوف تتجه إلى القسم الأدبــي،

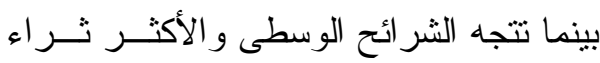

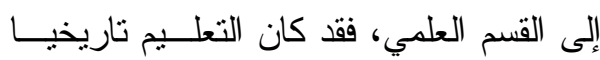

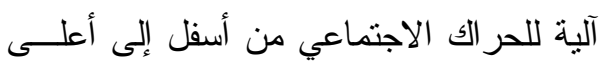

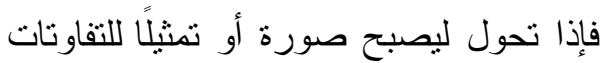

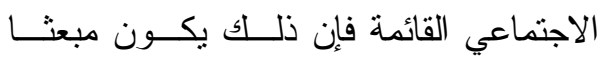
للخوف وللقلق المسـتمرين فـي المجتمــع المصري ( هلال، (196 19. ). يتضح من ذلك أن التعليم يعتمد أكثتر

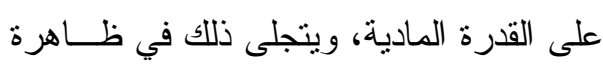
الدروس الخصوصية التي تفتت في جميـع المر احل التعلمية ولاسيما الثهادات الدراسية

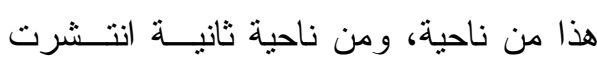

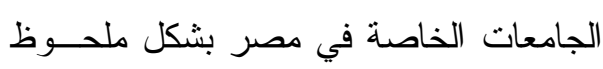
وكذلكك الجامعات الأجنبية التي تقبل طـــلاب

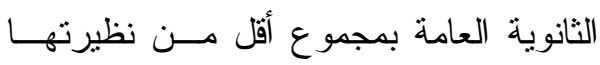

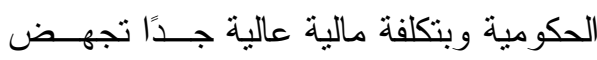

المؤسسات التزبوية و التعليمية ، و إن توفرت

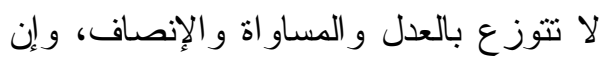
وزعت بالعدل فإنها لا تستمر ، و المحسوبية: تنتشر علاقات الوساطة و المحسوبية وتبــادل

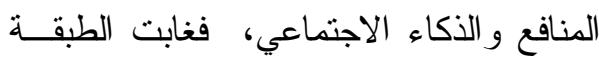

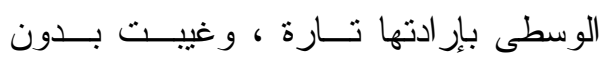

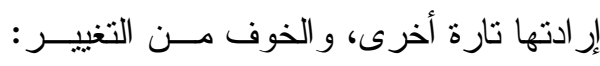

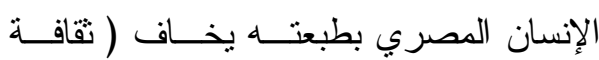

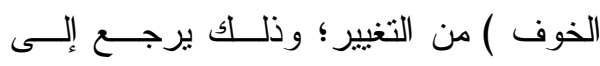

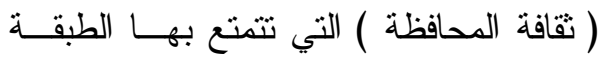

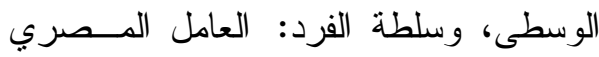
و الموظف وجميع فئــات الطبقــة الوســــى لونى يهتمون بتوجيهات رؤســائهم الديكتاتوريسـة

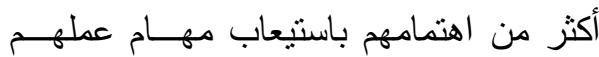

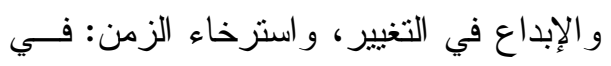
المجتمع المصري قد يمر وقت طويل ( فترة النلكؤ) دون فائدة ، و العمل كفريق: إن العمل العل كفريق في مصر لم يبلغ بعد المستوى اللائق

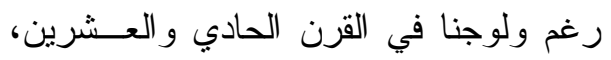
وضعف الرؤية الكلية: عدم تــــفر الرؤيسـة الكلية يؤدي إلى الواحدية، و التعصب، وقصد

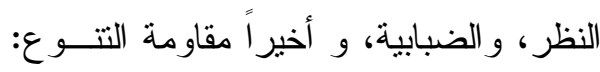

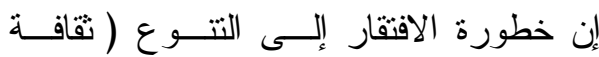

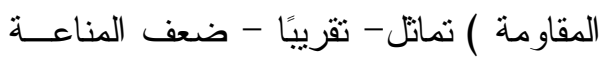

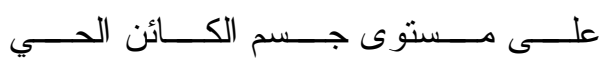
( حامد، ( ) ( ) (1999) 
الأنيا بنمط التعليم الحكومي و الأزهري، و أما أبناء الطبقات العليا فيلتحقون بــنمط التعلــيم

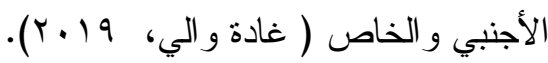

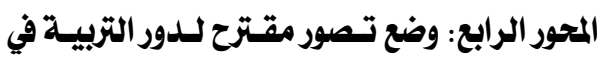

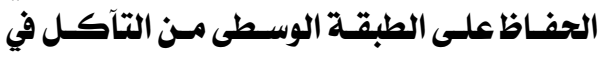

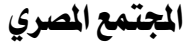

اثتثق هذا التصور من الآتي:

ا - الدر اسات السابقة

r- الجهود المبذولة من قبــل الحكومـــة

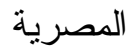

بـــ الجهاز المركـزي للتعبئــة العامــة

و الإحصاء

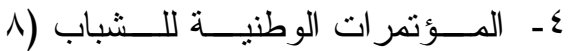

مؤتمر ات) و لاسيما المؤتمر السابع

0ـ ـ وزارة التعليم العالي و البحث العلمي

T- وز ورة الاستثمار و التعاون الدولي

وتوصلت الدراسة إلى النتائج و المقترحسـات

الآتية:

1- تكونت الطبقة الوسطى في مصر فـي

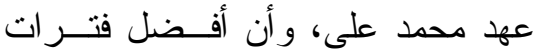

الطبقات الوسطى في مصر ازدهارًا هي

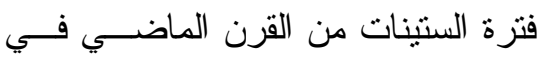

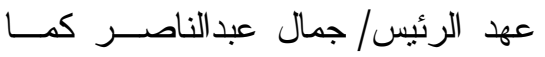

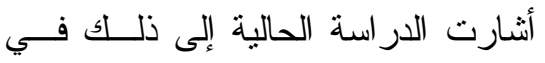

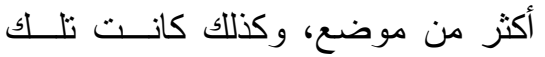

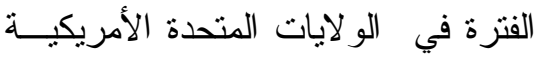

كاهل الأسرة المصرية ولاسـيما أن هنــاك

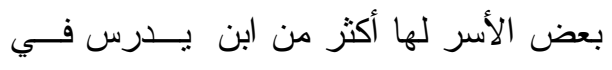

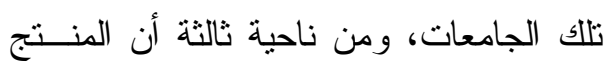

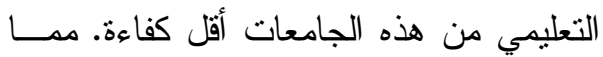

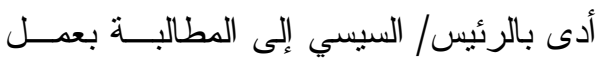

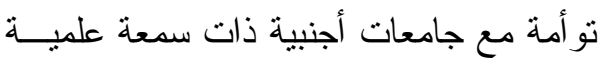

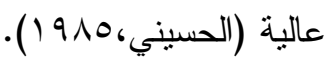
ومن الجدير بالذكر أن ارتفاع تكلفــة

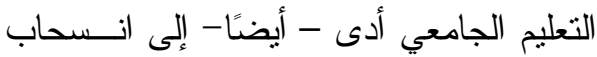
أبناء الطبقات الوسطى من الكليات في أمريكا .(CNN ,2019,Sep.15)

أين يفضل شر ائح الطبقــة الوســــى

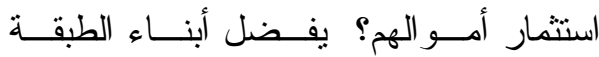

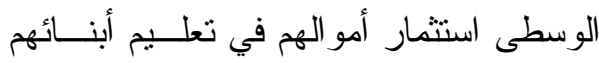

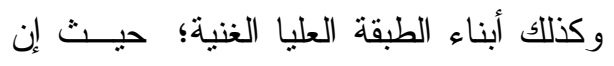
وجهة نظرهم في ذلك أن التعليم هو أفـضل فضل

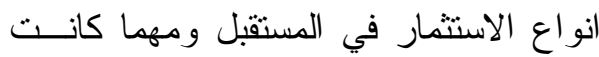

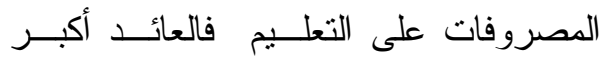
بكثير - ومن المعلـوم أن أكتهـر شـــريحة تأثرت بالإصلاحات الأخيرة هي الــشريحة

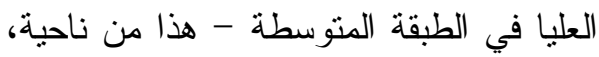
ومن ناحية أخرى تصرف الطبقة الدنيا معظم

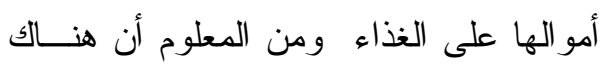

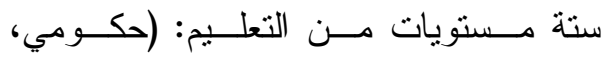
تجريبي، لغات، أزهري، أجنبي، خـاص). يلتحق أبناء الطبقة الوسطى بــنمط التعلـــيم

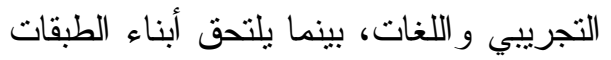




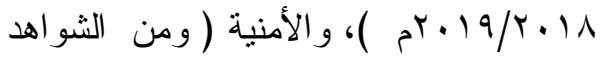

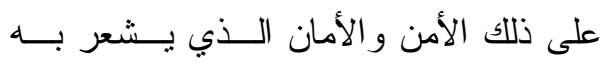

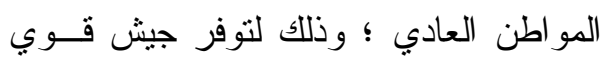
وشرطة يقظة ) (المؤتمر الـــوطني الثـامن

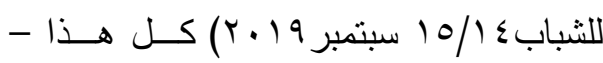
وغيره- تشهده الدولة المصرية في السنوات

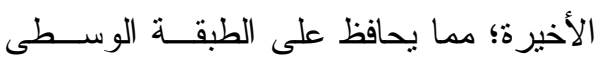
وينميها.

r- لم يعد المجتمع المصري يتكــون مــن

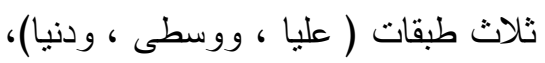
بل يتكون من خمـس طبقــات؛ حيــث انقسمت الطبقة الوسطى إلـى ثـلاث

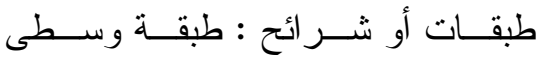
عليا Upper-Middle Class، وطبقــة وســــى فقبـــرة Lower- Class، وطبقة وسطى دنيــا Middle Class و وأحيانان يطلق عليها الطبقة الوســــى العاملـــة - Working

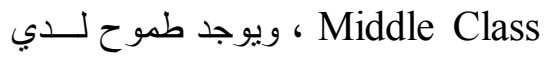
الطبقة الوسطى العليا للانتقال إلى الطبقة العليا، ويوجد خوف وقلق لدى الطبقــة الوسطى الانيا للهبوط إلى الطبقة الـــنيا

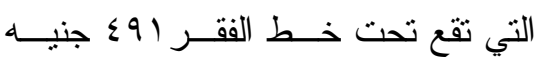

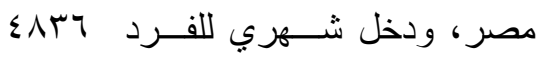

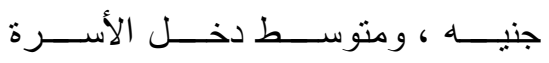

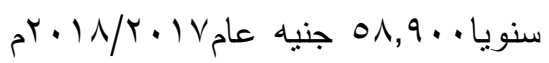

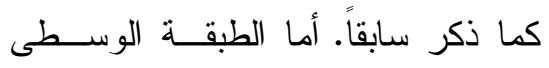

وكانوا يتمتعون بعقلية الطبقة الوســـى

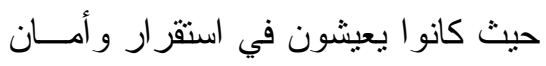

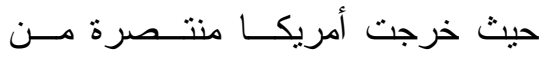
الحرب العالمية الثانية مع قوات التحالف ضد قوات المحور بقيادة ألمانيا ولم يكن لون

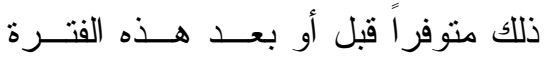

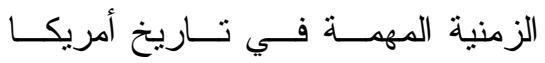
.(Maragou, 2015)

وتقترح الدراسة لتكوين عقلية الطبقة

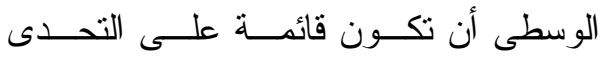
و المنافسة الثريفة و الطمـوح - و لاسـيـيمابعد الآداء الرئع لمشاركة الطبقة الوسطى في

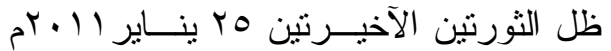

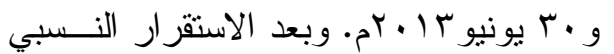

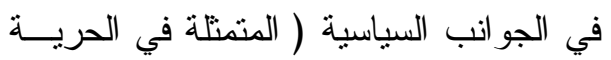

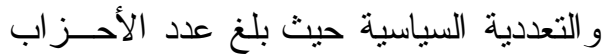

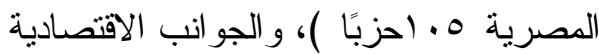

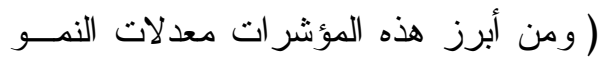

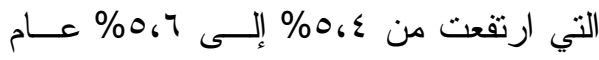

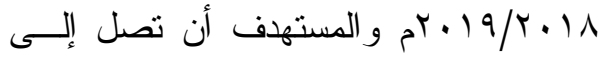

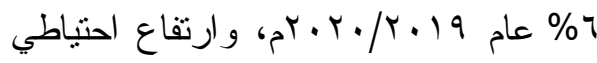

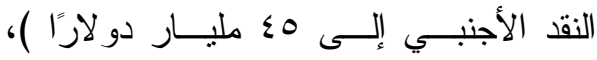

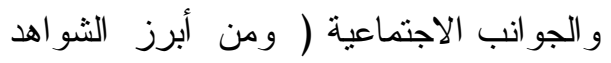
على ذللك تماسك نسبي للأسرة المصرية في

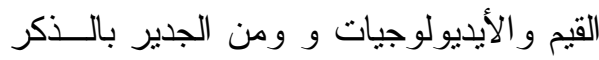
أن عدد الأسر وصل إلى بـ مليون أســرة وديات

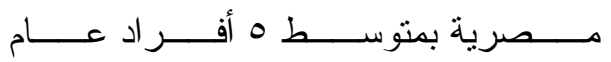




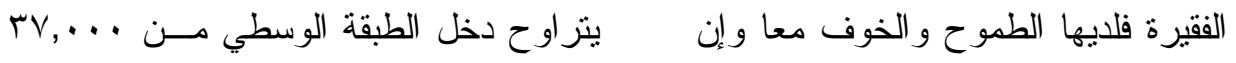

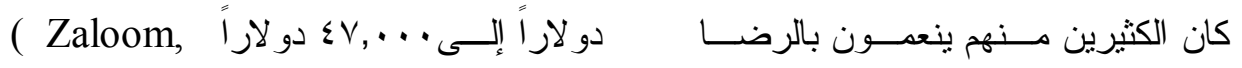

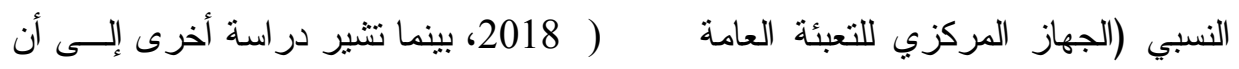

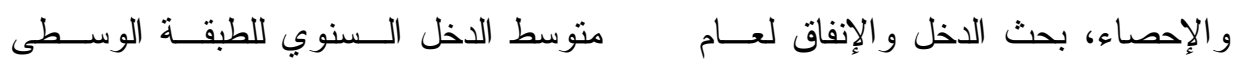

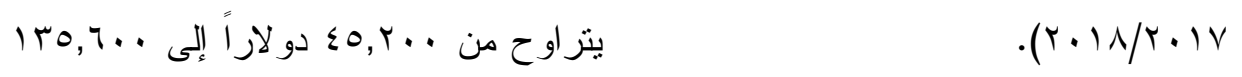

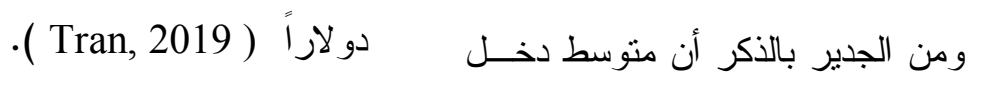

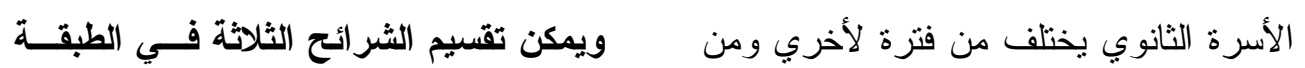

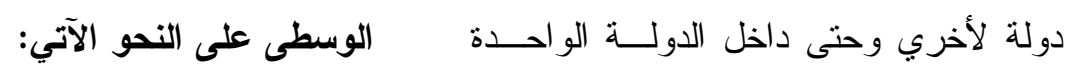

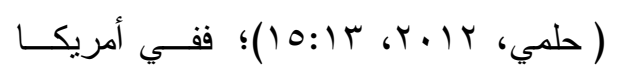

جدول ( 1 ) اقتراح تقسيم الثرائح الثثلاثة في الطبقة الوسطى

\begin{tabular}{|c|c|c|c|}
\hline طبقة وسطى عليا & طبقة وسطى فقيرة & طبقة وسطى دنيا & الاخل الثهري والسنوي \\
\hline 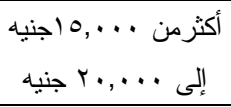 & 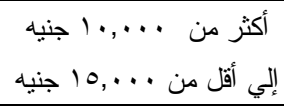 & |... & أو الثل الثهري للطبقات الثرسى \\
\hline 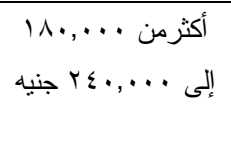 & 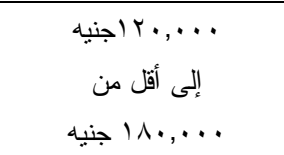 & . ..., . & أو الثر السنوي للطبقات الوسطى \\
\hline
\end{tabular}

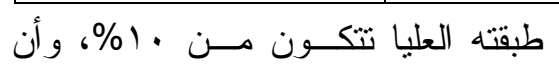

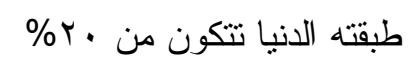

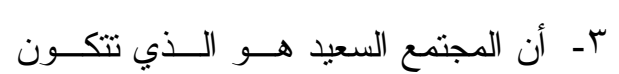

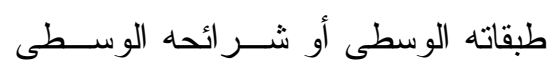

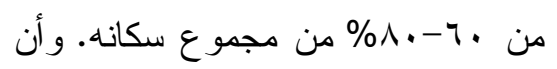

جدول رقم (11) اقتراح تقسيم التركيب الاجتماعي للطبقات الوسطى في المجتمع السعيد

\begin{tabular}{|c|c|c|c|}
\hline طبقة دنيا & طبقة وسطى & طبقة عليا & المجتمع السعيد \\
\hline$\% r$. & $\% \vee$. & $\% 1$. & الحالة الأولى \\
\hline$\% 1$. & $\% \wedge$. & $\% 1$. & الحالة الثانية \\
\hline$\% r$. & $\% 7$. & $\% r$. & الحالة الثالثة \\
\hline
\end{tabular}

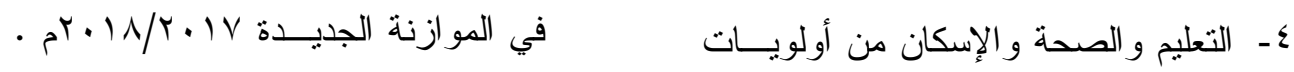

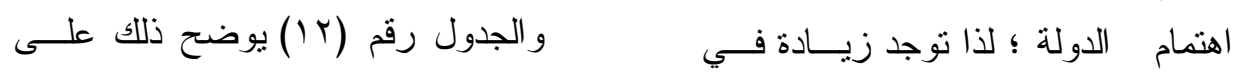

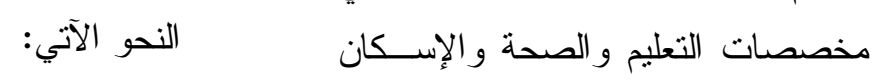


جدول رقم (r ا ) زيادة في مخصصات التعليم و الصحة والإسكان في الموازنة الجديدة

\begin{tabular}{|c|c|c|c|}
\hline \multicolumn{4}{|c|}{. } \\
\hline الزيادة الزياد & م.19/r.11 & م.1N/r.lv & القطاع \\
\hline أكثر من •r\% & r Vليار جنيه & آكليار جنيه & قطاع الصحة العامة \\
\hline$\%$ \%. & זٓ مليار جنيه & ror مليار جنيه & قطاع الإسكان \\
\hline$\% 1 r$ & كبا مليار جنيه & 110 مليار جنيه & قطاع التعليم \\
\hline
\end{tabular}

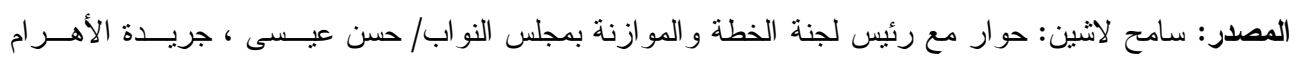

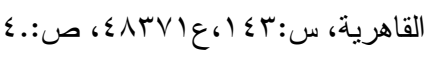

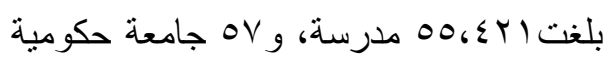
ويتضح من الجدول السابق (r I) الآتي:

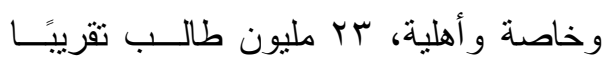

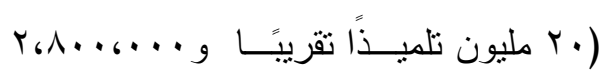

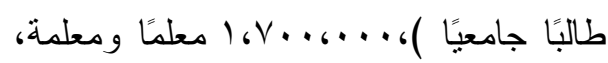
ومتوسط كثافة الفصل ارتفع إلى 0 ؛ تلميذًا.

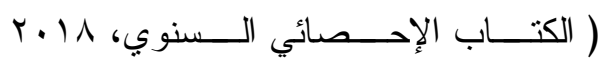
•rس:اسب)؛ ( المؤتمر الــوطني الثـامن.

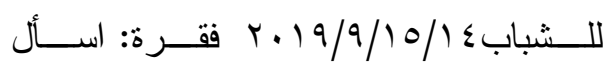
الرئيس ).

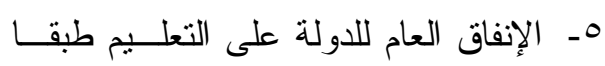

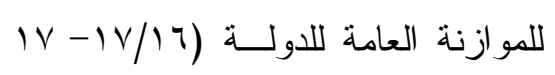

$$
(r \cdot) /
$$

يتضح من الجدول رقم (T/) الجهود المبذولة من قبل الدولة للإنفاق على التعلــيم لعلاج التفاوت الطبقـي وتحسـين المنــنج التعليمي على النحو الآتي: أن هناك زيادة في مخصصات التعليم

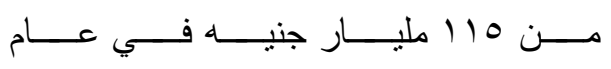

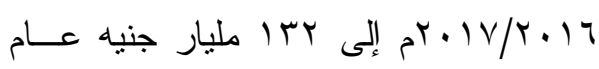

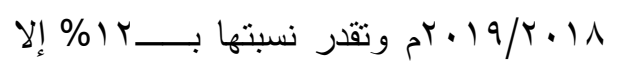
أن هذه الزيادة هي الأقل القطاعات الـثنلاث

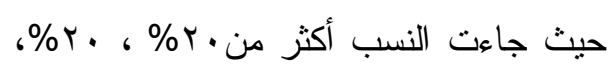
rا في قطاعات الصحة و الإسكان و التعلــيم

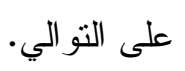

لذا تقتز ح الدراســة زيــادة النـسبة

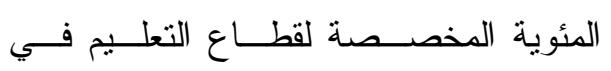

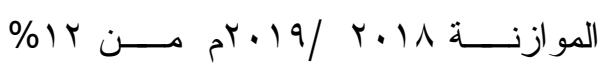

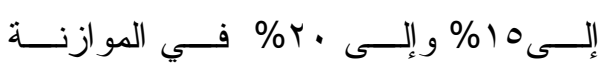

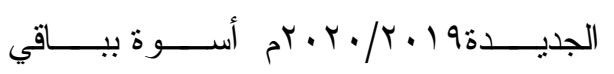

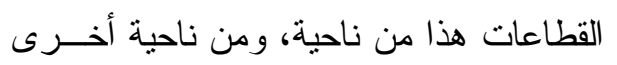

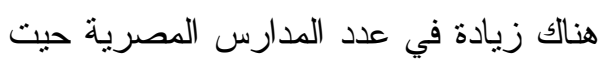


جدول رقم (r ا ) الإنفاق العام للاولة على التعليم طبقا للموازنة العامة للاولة

\begin{tabular}{|c|c|c|}
\hline \multicolumn{3}{|c|}{$(r+11 / 1 v-1 v / 17)$} \\
\hline $\mathrm{S}^{r} \cdot 1 \Lambda / r \cdot 1 \mathrm{~V}$ & $P^{r+1 V / r+1 r}$ & البيان البان \\
\hline$I_{6} r \cdot V_{6} \mid r_{1} \ldots$ & $9 \vee \varepsilon_{6} \vee 9 \varepsilon_{6} \ldots$ & الإنفاق العام للدولة \\
\hline $1 . v_{6} \cdot v_{0} \varepsilon \varepsilon$ & 1. T.97Y.r.. & الإنفاق العام على التعليم \\
\hline$\% \wedge, 9$ & $\% 1 \cdot . \vee V$ & نسبة الإنفاق العام على التعليم إلى \\
\hline
\end{tabular}

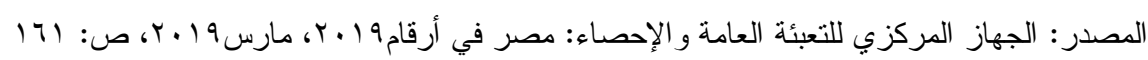

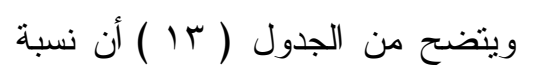

وتقترح الدراسة في هذا الصدد الاتي:

الإنفاق العام على التعليم إلى الإنفاق العام قد - توفير عمل إداري للطلبــة- و لاســـيما لأبناء الطبقة الوسطى - مقابل الإعفــاء تدنت من V، 1) I \%،9 من المصروفات و الرســوم الدراســية، أن يزيد الإنفاق العام للاولــــة علـــى التعلــيم مثل: العمل في المكتبة، و الكتابة علـى

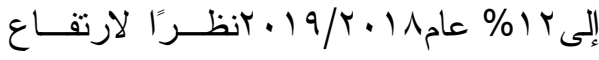
الكمبيوتز ، الاستعلامات - تتاوب التعليم بالكلية و التنريب في سوق العمل للطلبة في التخصصات المختلفة،

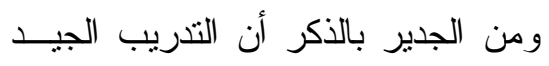

$$
\text { هو نوع من الربح. }
$$

- استثمار المهارات المتميزة لدى بعـض

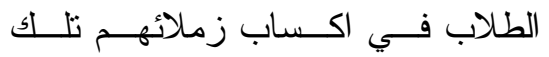
المهار ات الني تدر عائدًا مُجزيًا. V- إن الطبقة الوسطى رغم التحديات التـي

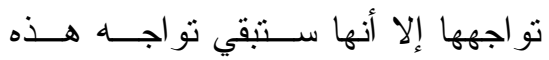

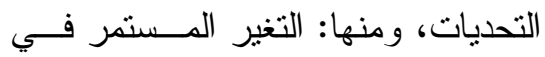
التزكيب الطبقي حيــث يــصعد إليهــا تكاليف ومستلزمات العملية التعليمية و المباني التعليمية، ومن الجدير بالذكر أن الدولة تبني

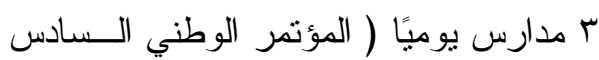
للنثباب) 1 - تقوم الدولة بتوفير قرض تعليهــي مــن

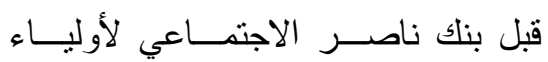

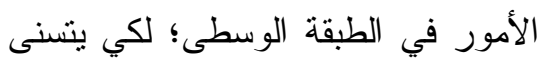

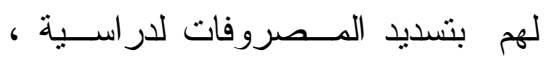

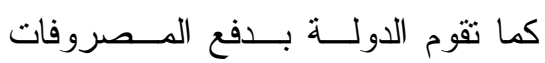

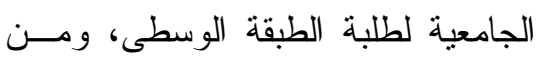

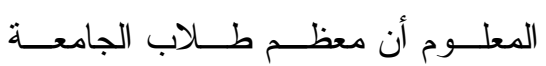
من الطبقة المتوســة ل (غــادة والــي، 


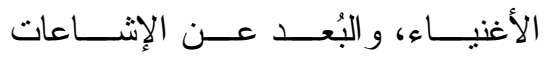

و الأكاذيب المضللة حول مصدر ثروتهم

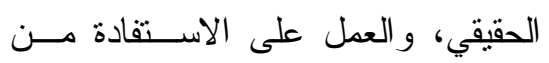

تجاربهم وخبراتهم في الدجالات العملية

المختلفة.

- يجب أن تقوم المدرسة بالتعـاون مــع

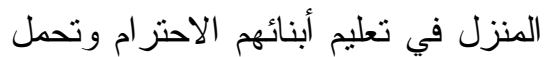

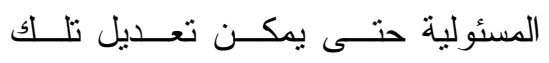

النظرة ) Lickona, 1991, 23:34)

^- نوجد عدة آليات يو اجه بها أبناء الطبةــــة

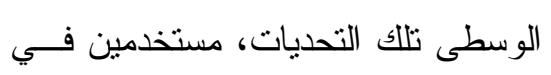

ذلك عدة أساليب، منها: نقليل الأنشطة

المكلفة، منل: الرحلات و الترفيه، وتقليل

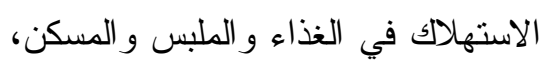

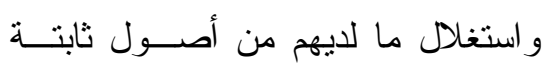

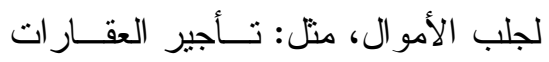

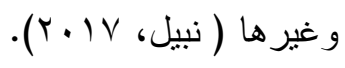

وتقترح الدر اسة في ذللك الآتي:

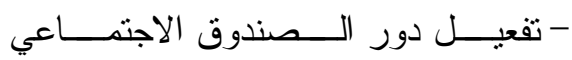

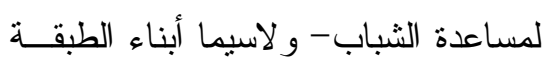

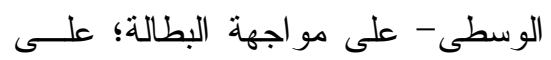

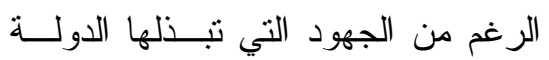

( انخفاض ملحوظ البطالة فـــي الآونـــة

الأخيرة)

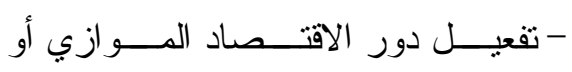

الاقتصاد غير الرسمي أو اقتصاد بيــر
شرائح من الطبقة الدنيا ويهــبط فيهـــا

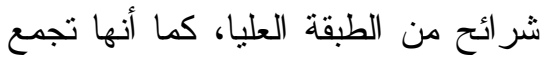
بين الأصالة و المعاصرة ؛ حيت تهـتم بالجانب الديني و الأخلاقي في العـادات و التقاليد وتحافظ عليها وجانب الحداثــة

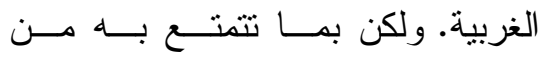
خصائص أخلاقية وتربويــة وتعليميــة

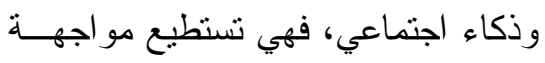

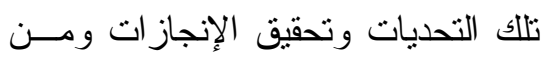

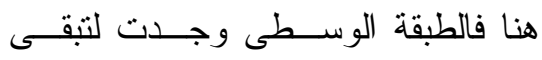

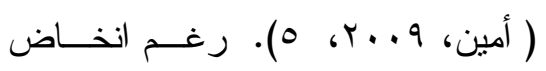

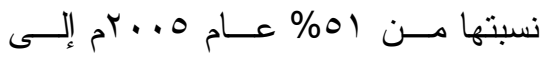

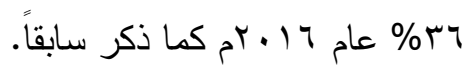
وتقترح الاراسة في هذا الصدد الآتي: - ان تحافظ الطبقة الوسطى على نفـسـها

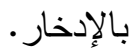
- و إذا أر اد أبناء الطبقة الوسطى الولـــــــ للطبقة العليا فعليهم بالاستثمار، وتتويــع

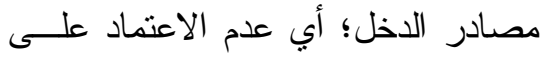
الوظيفة أو المهنة الواحدة فقط، والبحث عن عمل إضافي. - و إذا أر اد أبناء الطبقة الوســطى عــدم

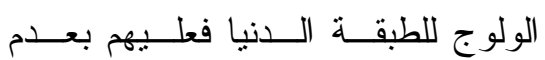
الإسر اف، وترشيد الإنفاق.

- تعديل النظرة السلبية مــن قبــل أبنــــاء الطبقة الوسطى نحو أبناء الطبقة العُليــا لنطاء 


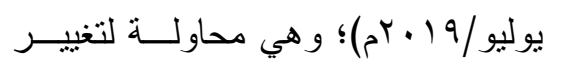

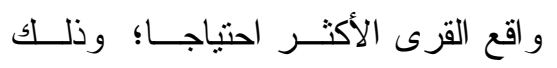

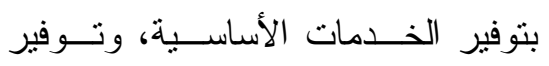

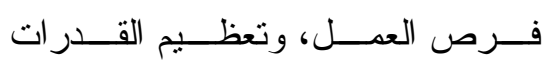
الانتاجية. وتقترح الارسة في هذا الصدد الآتي:

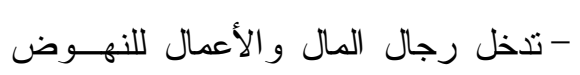
بالقري الأكثر احتياجًا. - تقديم أغنياء الطبقة العليا الموارد المالية و المادية للقري التي آتو ا منها في صورة الفولئه - مشروعات، ومتابعة تتفيذها، وتقويمهـا وتطوبر ها بصفة دورية. - بناء مدارس ومستشفيات مــن أمسـو ال الزكاة و الصدقة في تللك القرى الأكثــر

$$
\text { احتياجًا. }
$$

- تحويل نسبة من تحـــويلات المــصريين

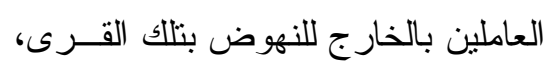

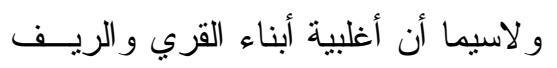

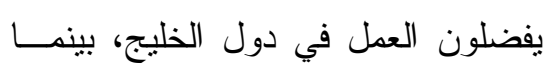

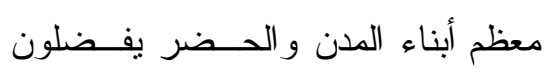

$$
\text { العمل في أوروبا و أمريكا. }
$$

- نشر الثقافة الزر اعية في القرى من قبل

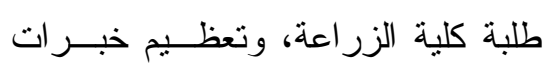

$$
\text { الفلاح }
$$

- المصري في الحرث، و الزرع، وترشيد استخدام مياه الري.
السلم من قبل الدولة بــالاعتر اف بــه،

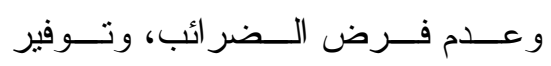
المساعدات المالية، و والتطوير المستصر

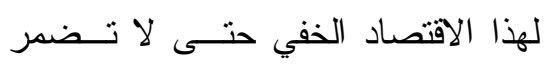

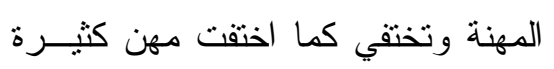

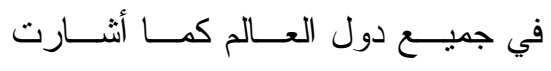

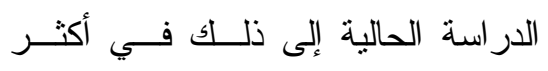
موضع. - نشر الوعي الديني الصحيح من خــلد لـول

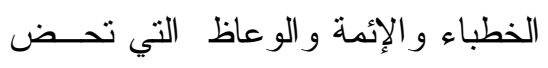
على عدم الإسر اف و عدم الإنفاق بسفه.

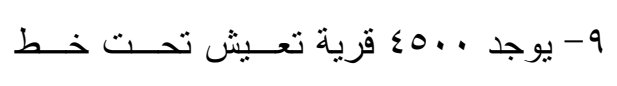
الفقروتختلف نسب الفقر في كل منهاكما

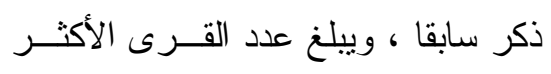

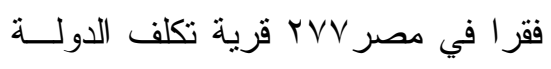

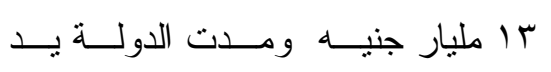

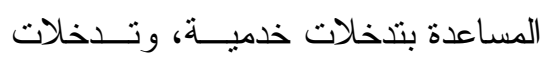

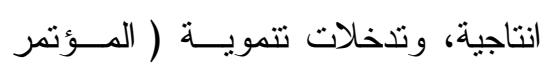
الوطني السابع للشباب ( ابدع- انطلق )

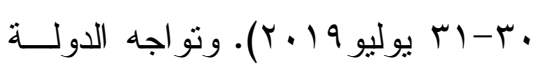

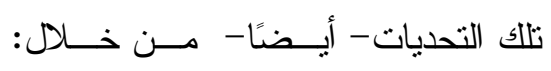
برنامج تكافل وكر امة، ودعـــ بطاقـــة

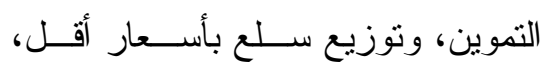

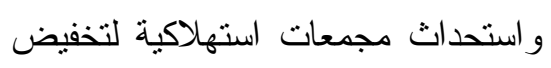

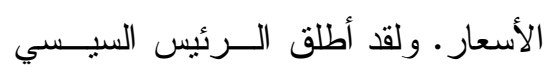

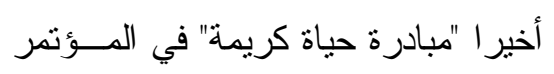

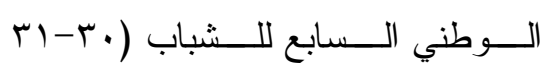




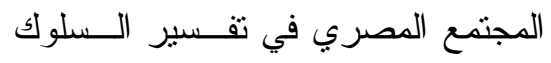
الطبقي صعوداً وهبوطاً و عمقاً، ونــشر فئر

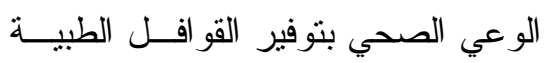

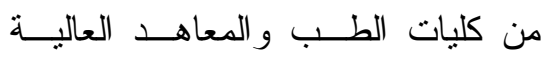
للتمريض، ونشر الوعي الثقافي بتــوفير

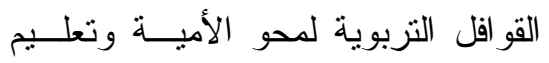

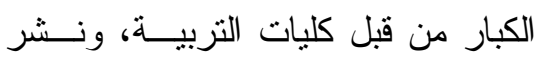
الوعي القانوني بنوفير القو افل من كليـــة الحقوق لعدم تزبيف الوعي.

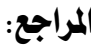
'. أبوحطــب، فــؤاد اد ، صـــادق ، آمـــال

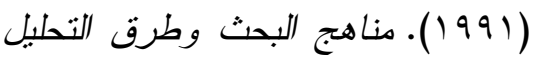

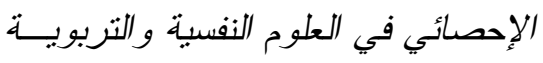
و الاجتماعيــة. طا ا، القـــاهرة: مكتبــــة الأنجلو المصرية.

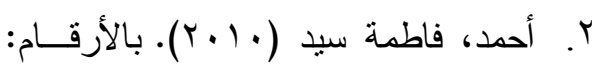

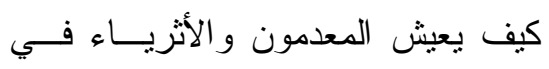
مصر ، مجلة روزاليوسف الأســبوعية، لئل

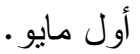

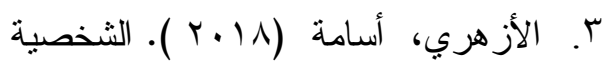
المــصرية. خطــــوات علــى طريــق المستقبل. سلسلة كتاب اليــوم الثقافــة، 70V ـ. البطريــقن، نــسمة أحمـــــ (1999). التليفزيون و المجتمع و الهوية النقافيـة.

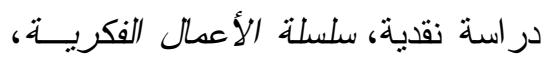

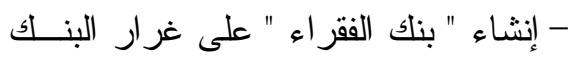
الذي أنثأه " محمد يونس" في باكستان. • ا- نقـــوم منظمـــات المجتمـــع المـــنـي و الأحزاب السياسية بنشر الوعي الطبقي من خلال المقترحات الآتية: - الندو ات و المؤتمر ات و المعارض الفنـــــة

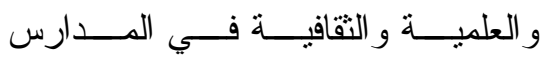
و الجامعات وقصور الثقافة. - تفعيل دور الإعــام الاجتمــاعي فــي التليفزيون و الر اديو و الصحف ووســائل التو اصل الاجتماعي. - إلقاء مزيد من الضوء حول علماء علـــ الاجتماع الريفي والحضري، وضرورة

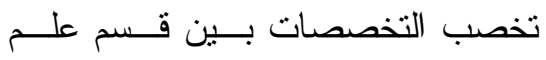
الاجتماع بفروعه المختلفة، منها: ( علم

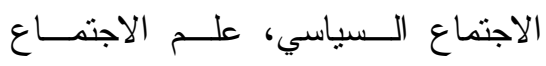
الاقتصادي، علم اجتماع المعرفة) فــي الاجي

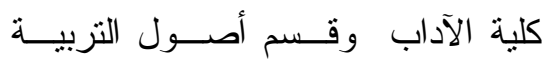

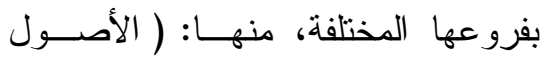

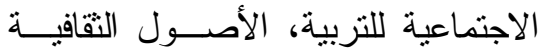
للتربية، الأصول السياسية للتزبية) فــي لإهي

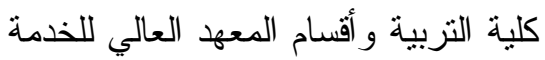
الاجتماعية. - توفير الدراسات و البحوث الاجتماعيــة حول المتحولين من طبقة إلى أخــرى،

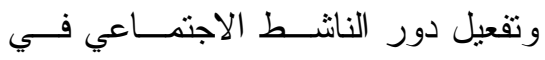


l'. الدسوقي، عاصــم (Y (Y). ثــورة

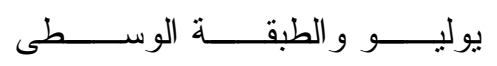
http://www.alfikralarabi.org $.14 / 8 / 2019$

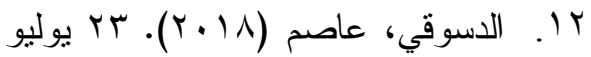
ورة الأم الث

http://www.octobermageg.co m 21/7/2018

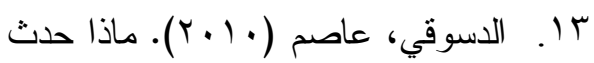

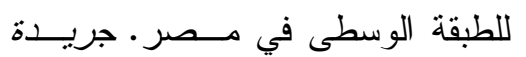

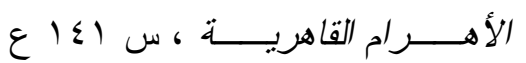

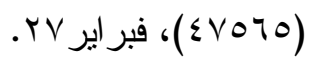

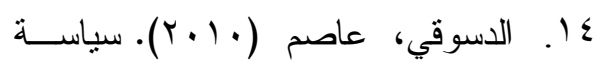

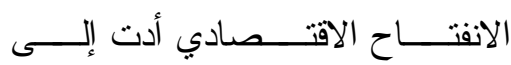

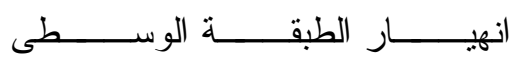
http://www.coptsunited.com. 30/10/2010 1. . الثعر اوي، محمــــ متــولي، (د.ت).

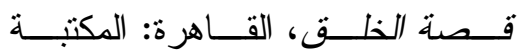

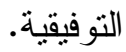

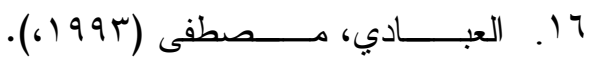

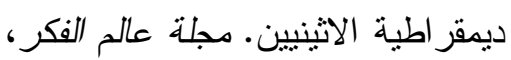

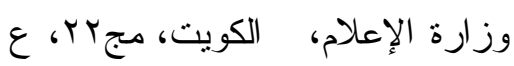

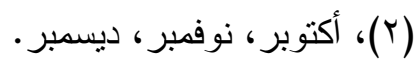
IV الر امخ، محمد السيد محمد (1994). محددات البناء الطبقي ودينامياته فـي لـي

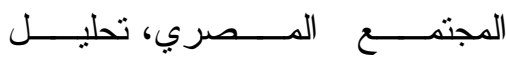
سوسيولوجي فـي الفتــرة (90r)
مكتبة الأسرة. مهرجان القراءة للجميع،

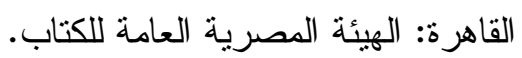

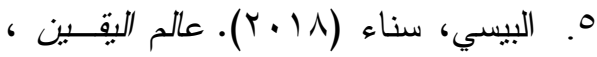
القاهرة: دار نهضة مصر.

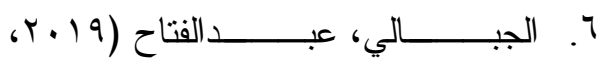

أغسطس (Y). الفقر اء ومصيدة الفقــر .

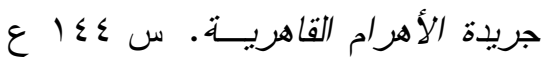
. $(\varepsilon \wedge \varepsilon \vee \cdot)$

V. الجهــاز المركــزي للتعبئـــة العامـــة و الإحصاء (1) (Y). الجهاز الإحصائي

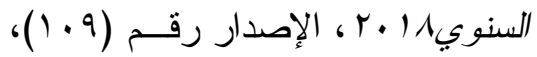
مرجس رق القاهرة: الجهاز المركزي للتعبئة العامة و الإحصاء.

^. الجهـــاز المركــزي للتعبئـــة العامــــة

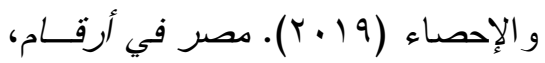

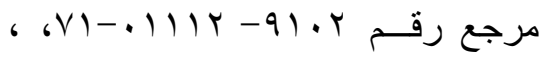
القاهرة: الجهاز المركزي للتعبئة العامة و الإحصاء، مارس.

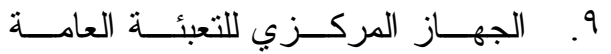
و الإحصاء، إحصاءات تحت المجركر الجراء

Capmas.Gov.eg W/8/2019 WWW.

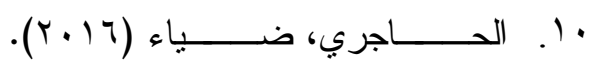
التكنولوجيا و والسياسة. القاهرة: مركز فياء

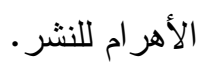


عـــنان سـليمان، سلــسلة الرضــــا

للمعلومات، و ب، ، دمثق - ســوريا:

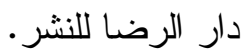

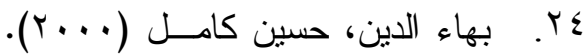

الوطنية في عالم بلاهويــة. سلــسلة

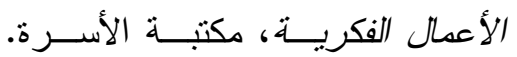

مهرجان القر اءة للجميــع، القـــاهرة: الهيئة المصرية العامة للكتاب.

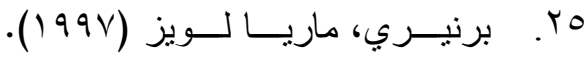

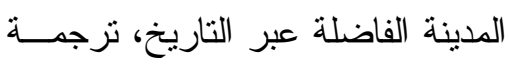

عطيات أبو الــسعود. سلـسلة عــالم

المعرفــة، rYO، المجلـس الــوطني

للتقافة و الفنون و الآداب، الكويت.

4T. . حامــــ، محمــــــ رؤوف (1999).

الوطنية في مو اجهة العولمة، سلــسلة

|قرأ I I I ، القاهرة: دار المعارف.

Y V. حسنين، جمال مجدي (19V^). ثورة

يوليو ولعبة التوازن الطبقي. القاهرة:

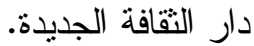

א r. حسنين، جمال مجدي (1911). البناء

الطبقي في مصر ، القاهرة: دار النقافة

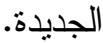

q.r. حلمـي، عمـرو (r) (Y). صــعود

الأمم. سباق الثقلدم وصناعة المستقبل:

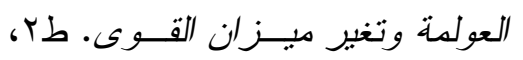

القاهرة: كلية الآداب.
1911)، أطروحة دكتوراة ، كلية

الآداب، جامعة الأسكندرية.

11. الزيات، السيد عبدالحليم (.999). في

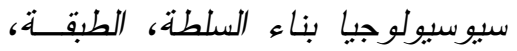

القوة، الــصفوة، الإنــكندرية: دار

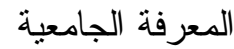

9 1. أمين، جلال (YlV). (Y). سياسة الانفتاح

الاقتصادي أدت إلى انهيــار الطبقــة الطية

الوسطى في مصر ، جريدة الأقبـاط

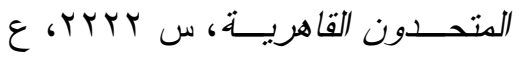

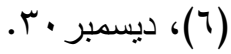

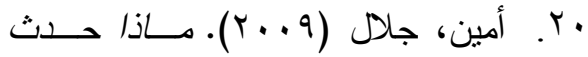

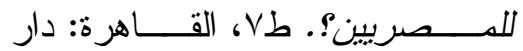

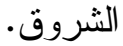

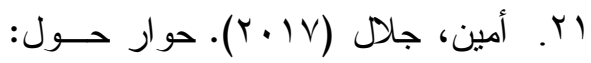

اختفاء الطبقة المتوسطة في مـصر . http://WWW.VideoYoum7.C om 24/11/2017

Y. Y. بكــر ، محمــد إبــر اهيم (Y) (Y).

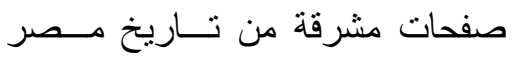
القديم، سلسلة علوم اجتماعية، مكتبــة

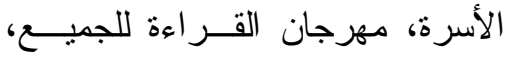
القاهرة: الهيئــة المــصرية العامــة العنة

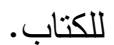
rr . . بوكسبرجر ، جير اك و كليمنتا، هار الد (999، (199). الكذبات العشر للعولمـــة. بدائل دكتانوريــة الـسوق، ترجمــة 


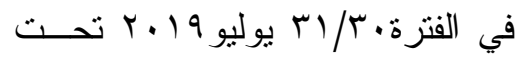

رعاية الـسيد رئسبس الجمهوريــة عبدالفتاح السيسي.

بr. رئاسة الجمهورية (19 (Y). المؤتمر الوطني الثامن للثباب (ابدع- انطلق) المنعقد في التجمع الخامس في الفترة

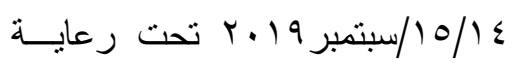

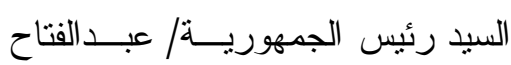
السيسي. rV

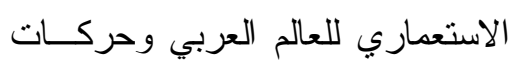

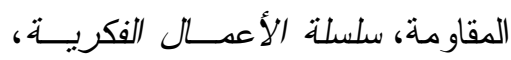

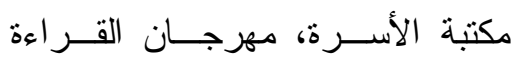

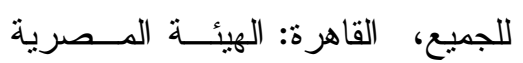

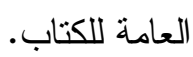
مب. رمضان، هويدا عبدالعظيم (999 (1). المجتمع في مصر الإسلامية. سلسلة

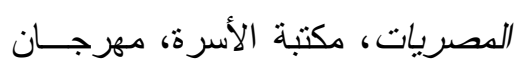

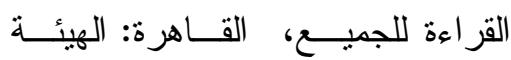
المصرية العامة للكتاب.

رومان، هويدا عدلي (1 . . ب). الطبقة الوسطى في مصر • در اســـة نوثيقيــة

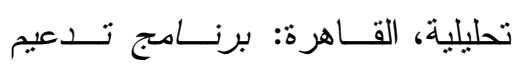
المشاركة في بحوث التنمية.

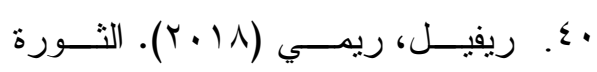
الرقمية، ثورة نقافية، ترجمـــة ســـيد ريد •r. خباز، حنــا ( (910) ). جمهوريسـة

أفلاطون (مترجم )، بيروت- لبنــان: دار القلم.

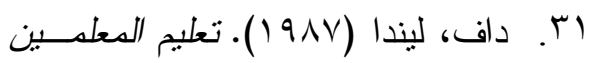

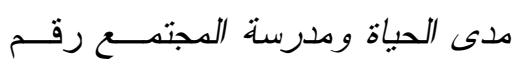

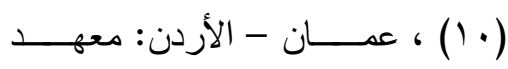

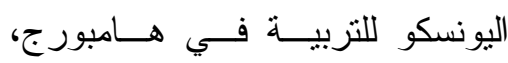
جمهورية ألمانيا الاتحادية سابقا.

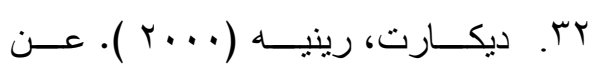

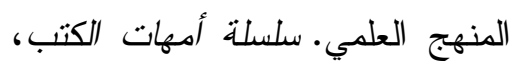
مكتبة الأسرة، مهرجـــان القــر اءة

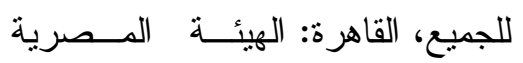
العامة ل ل الكتاب.

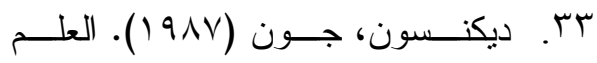

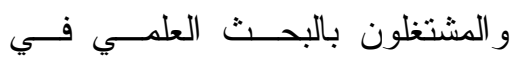

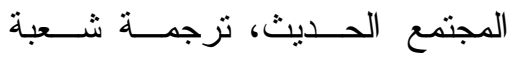
التزجمة باليونسيكو ، سلـسلة عـالم

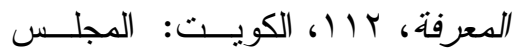
الوطني للتقافة و الفنون و الآداب. ع r. راتب، حسن (19 (r). عودة الطبقة

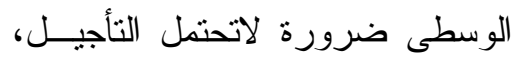

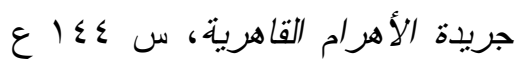
( أغسطس هب. رئاسة الجمهورية (19 (ب). المؤتمر الوطني السابع للثباب (ابدع- انطلق) المنعقد في العاصمة الإدارية الجديــدة 


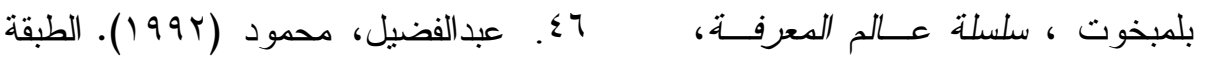

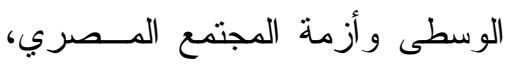

$$
\begin{aligned}
& \text { مجلة الهلال القاهرية، بناير. }
\end{aligned}
$$

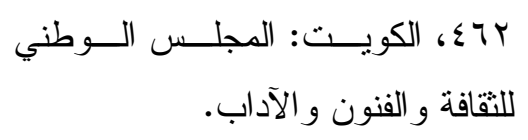

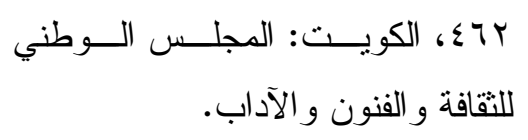

$$
\begin{aligned}
& \text { SV }
\end{aligned}
$$

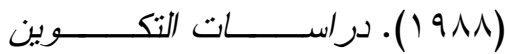

$$
\begin{aligned}
& \text { الاجتماعي والبنية الطبقية في مصر، } \\
& \text { الدراسات المحلية، القاهرة: المركـز } \\
& \text { القومي للبحوث الاجتماعية و الجنائية. } \\
& \text { ^ء. علي، نبيل (1) }
\end{aligned}
$$

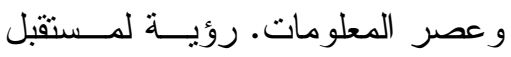

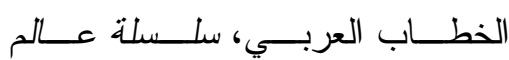

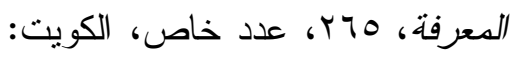

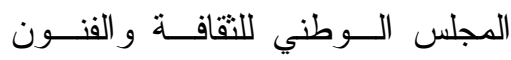

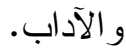

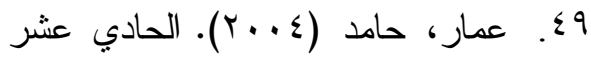

$$
\begin{aligned}
& \text { مــن ســبتمبر وتداعياتـــه التزبويــة } \\
& \text { و الثقافية في الوطن العربي، سلـسلة } \\
& \text { آفاق تربوية مستجدة، القاهرة: الــدار } \\
& \text { المصرية اللبنانية. } \\
& \text { •. . عمار، حامد (997) (199.) مقالات فـي } \\
& \text { التتمية البشرية. سلسلة دراسات فـي هي }
\end{aligned}
$$

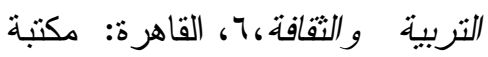

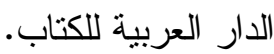

$$
\begin{aligned}
& \text { 0. أديــب، عـــرو (1) (Y). مــصر } \\
& \text { و العالم- لقاء خاص مع غادة والــي }
\end{aligned}
$$

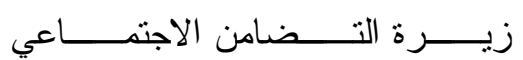

$$
\begin{aligned}
& \text { اء. زقزوق، محمــود حمـدي (YIV) } \\
& \text { الفكر الديني وقضايا العصر ، سلـسلة }
\end{aligned}
$$

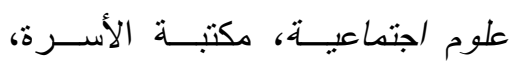

$$
\begin{aligned}
& \text { مهرجان القراعة للجميــع، القــاهرة: } \\
& \text { الهيئة المصرية العامة للكتاب. }
\end{aligned}
$$

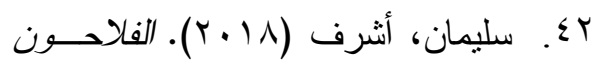

$$
\begin{aligned}
& \text { والسلطة والتتهية، القــاهرة: الهيئــة } \\
& \text { المصرية العامة للكتاب. }
\end{aligned}
$$

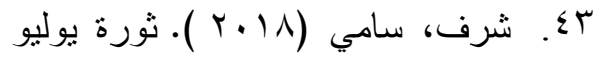

$$
\begin{aligned}
& \text { و الطبقة الوسطى، جريـــة الأهــرام }
\end{aligned}
$$

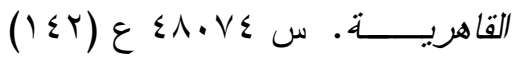

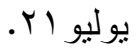

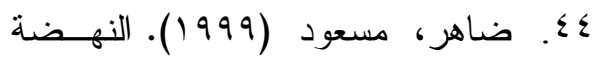

$$
\begin{aligned}
& \text { العربية و النهــضـة اليابانيــة. تـشـابه } \\
& \text { المقدمات و اختلاف النتــائج، سلــسلة اليلة }
\end{aligned}
$$

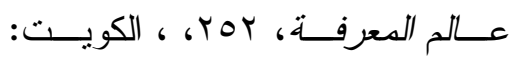

$$
\begin{aligned}
& \text { المجلس الــوطني للتقافـــة و الفنــون } \\
& \text { و الآداب. }
\end{aligned}
$$

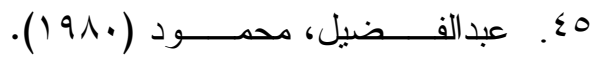

$$
\begin{aligned}
& \text { الاقتصاد الدـصري بـين التخطـيط }
\end{aligned}
$$

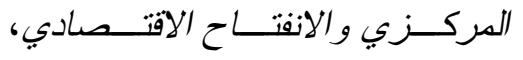

$$
\begin{aligned}
& \text { بيروت-لبنان: معهد الإنماء العربي. }
\end{aligned}
$$


OV

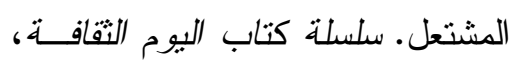
طء، القاهرة: دار أخبار اليوم.

ه. . محمود، محمد عبدالحميــــ إبـر اهيم

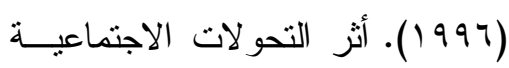

على بنية الطبقة الوســــ بالمدنيــة المصرية خلال الفترنين • V-.99 | در اسة مقارنة بين نمطين حضريين،

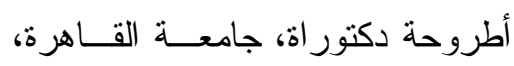

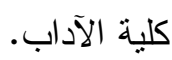

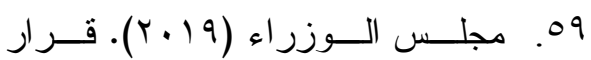

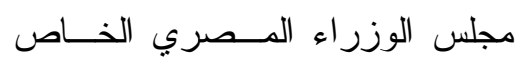
بالحد الأدنى للأجور ، القاهرة: مجلس الوزل

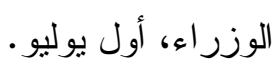
• 7.

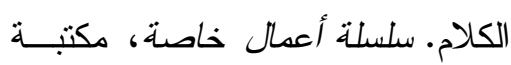

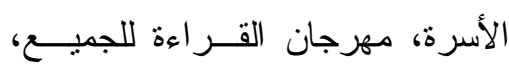

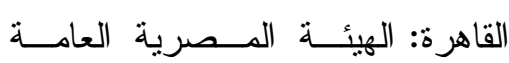
للكتاب. ا7. مؤنس، حسين (9911). الحــضارة.

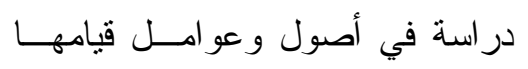

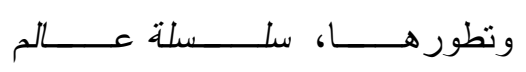

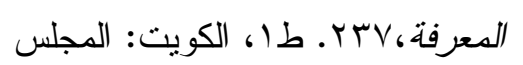
الوطني للنقافة و الفنون و الآداب. rT. هلال، على الــدين (19 (ب). دلالات ارتفاع مجاميع الثانوية العامة، جريبة
Alhayahhlive1/ 5/2/2018 http://bit.ly/

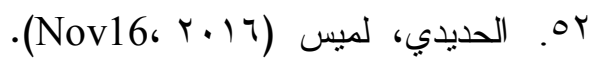

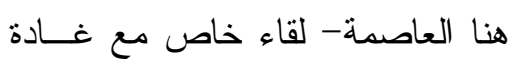
و الي وزيرة التضامن الاجتماعي http://WWW .CBC.egy.Com/cbc 16/9/2017

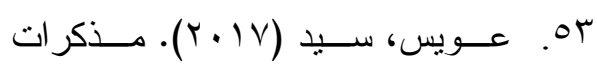

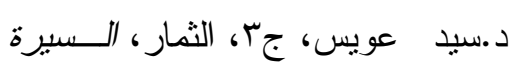
الذاتيةr r ، القاهرة: الهيئة المــصرية العامة للكتاب.

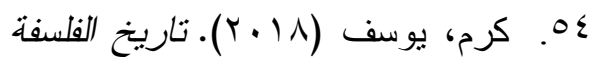

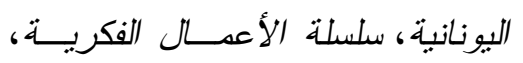

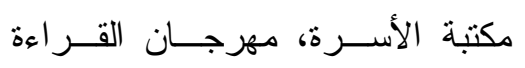

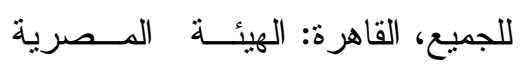
العامة للكتاب.

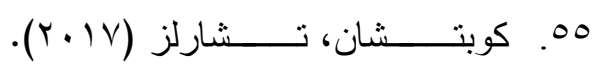
عالم واحد للجميـعم.شــروق عـالم للجميع بلا وصــي، ترجمــة كمــال

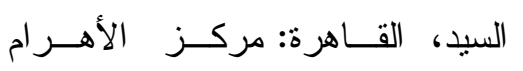

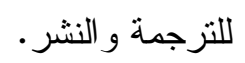

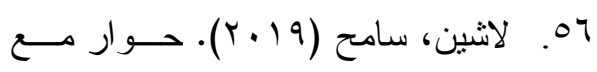

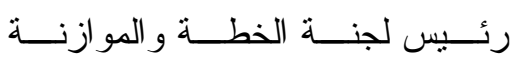

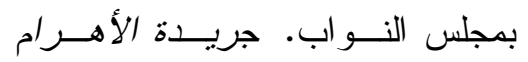

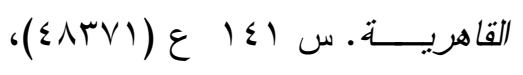
ص 
3. Bassis, M., Gelles, R. \& Levine, A., ( $1990 \quad$ ). Sociology: An Introduction. $4^{\text {th }}$ ed. New Yourk-USA, McGraw-Hill.

4. Borg, W .R. (1980). Applying Educational Research: A Practical Guide for Teachers, New York-USA, longman Publisher.

5. Cambridge English Dictionary ( 2019 ). Middle-Class. from www.

Dictionary.

Cambridg.Org. 30/8/,2019

6. CNN (2019, Sep.15). Rising College Costs Threaten the Middle - class, Avaliable from http://WWW.edition.CNN.Co $\underline{m}$ on $15 / 9 / 2019$ Videos

7. Crozier, G., Reay, D., \& James, D., (2008). White Middle-Class Parents, Identities, Educational Choice and the Urban Comprehensive School: Dilemmas, Ambivalence and Moraal Ambiguity, British Journal of Sociology of Education; V29 $\mathrm{N}(3), 261-272$.

8. Cucchiara, M.B. \& Horvat, E.M. (2009). Perils and Promises: Middle-Class parental Involvement in Urban Schools. American Educational Research Journal (AREJ); V $26 \mathrm{~N}$ (4).

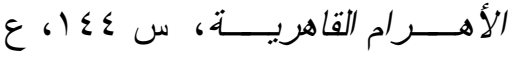

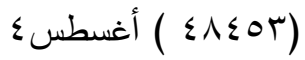

$$
\begin{aligned}
& \text { با7. وزارة الأوقاف و المجلـس الأعلــى }
\end{aligned}
$$

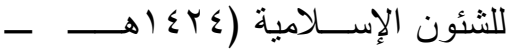

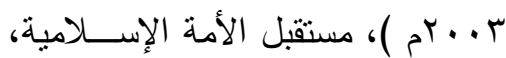

$$
\begin{aligned}
& \text { سلسلة قضايا إسلامية (99)، القاهرة: }
\end{aligned}
$$

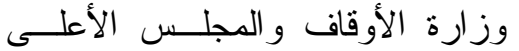

$$
\begin{aligned}
& \text { لـ اللشئون الإسلامية. } \\
& \text { ع7. ـ وهبة، مر اد (999 1). ملاك الحقيقـة }
\end{aligned}
$$

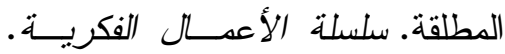

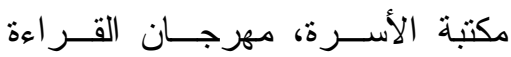

$$
\begin{aligned}
& \text { للجميع، القاهرة: الهيئــة المـصرية }
\end{aligned}
$$

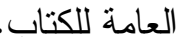

$$
\begin{aligned}
& \text { 70. ياســين، الــسيد (1999). العولمــة }
\end{aligned}
$$

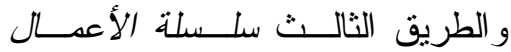

$$
\begin{aligned}
& \text { الفكرية، مكتبـــة الأســــة مهرجــان } \\
& \text { القـــر اعة للجميــع، القـــاهرة: الهيئـــة } \\
& \text { المصرية العامة للكتاب. }
\end{aligned}
$$

1. Arkinson, A.B. \& Branolinig, A. (2011). On the Identification of the Middle Class. ECINEQ. Society for the Study of Economic Inequality Working Paper Series. from WWW. ecineq. org.

2. Lickona,T., (1991) Educating for Character. How our School Can Teach Respect and Responsibility, New YorkUSA. 
16. Madland, D. ( 2011 ). Growth and the Middle Class, Symposium, First principles: Arguing Economy, Democracy A Journal of Ideas, N.(20)

17. Manyika, J. ( 2019 ). Thomas L. Friedman: Lifting people back into the Middle - Class. Mckinsey

Global Institute/Video

18. Manstead, A. S. R. ( 2018 ). The Psychology of Social Class: How Socioeconomic Status Impacts Thought, Feelings, and Behaviour. The British Journal of Social Psychology, V57 N(2) 267291.

19. Maragou, H. ( 2015 ). Lawrence R. Samuel, The American Middle Class: A Cultural History, European Journal of American Studies. Reviews 2015-1

20. Morneau, W. F. ( 2019, March19 ). Investing in the Middle Class. Department of Finance in Canada. Avaliable from WWW.finigc.Ca. On $30 / 8 / 2019$

21. OECD ( 2019 ).Under Pressure: The Squeezed Middle - Class. Overview and Main Findings. OECD. ISBN 978-94-54283-9

22. Posey-M., Kimelberg,S \& Cucchiara,M., ( 2014 ). Middle- Class Parants and
9. Duflo, E. \& Banerjeeat, A. ( 2008 ). What is Middle- Class bout the Middle Classes around the World? Journal of Economic Perspectives; V 22 $\mathrm{N}(2)$.

10. Defining the middle class/putting inequality on the map.

From www.

TheBrokeronline.eu.

18/8/2018.

11. Eichelberger, R. T. (1989). Disciplined Inquiry:

Understanding and Doing Educational Research, New York-USA, longman.

12. Freire, P. \& Macedo, d. ( 1987 ). Literacy: Reading the Word and the World. New YorkUSA, Bergin \& Garvey Publisher.

13. Frankenfield, j. ( 2019 ). Which Income Class Are You? Avaliable from WWW. Investopedia. Com. 4/6/2019.

14. Europen Commission ( 2019, Sep. ). Poverty, Middle - class and Purchasing power. Avaliable from http://WWW.ec.europe.eu. $15 / 9 / 2019$

15. Institute for Research on Poverty \& University of Wisconsin-Madison. ( 2010 ). Middle Class in America. FOCUS. V27 N(1) 
27. Smith, M. P. ( 2012 ). The Middle-Class Nature of Identity and its Implications for Education: A Genealogical Analysis and Reevaluation of a Culturally and Historically Bounded Concept. Integr Psych Behv. V46

28. Tarkhnishvili, A. \& Tarkhnishvili, L. ( 2013 ). Middle Class: Definition, Role and Development. Global Journal of Human social Science,Sociology \& Culture. V13 N(7).

29. Tran,T. ( 2019 ). What is Middle - Class? Avaliable from WWW.willteachyoutoberich.c om on 8/9/2019

30. World Bank \& Pew research Center (2019, Sep.19).How Well-off is China"s middleClass? Avaliable from http://WWW.Chinapower.Csis. org on 19/9/2019.

31. Zaloom, C. ( 2018 ). Does the U.S. Still Have a Middle Class? Avaliable from WWW.theatlanic.Com on 4/11/2018
Urban Public Schools: Current Research and Future Directions. Sociology Compass.V8 (4)

23. Pezzini,M.,( $2019 \quad$ ) An Emerging Middle Class,OECD Observer, Avaliable from WWW.m.oecdobserver.Org on 14/9/2019

24. Reary, D., Crozier, G., \& Clayton, j. (2013). " Fitting in" or " Standing out": Workin Class Students in UK Higher Education, British Educational Research Journal, V36 N(1)

25. Reay, D., (2008). Psychological Aspects of White Middle-Class Identities: Desiring and Defending against the Class and Ethnic 'Other' in Urban Multi-ethnic Schooling, Sociology, V42 N(6) 1077-1088

26. Shepard, J. M. ( 1990$)$. Sociology (5 ${ }^{\text {th }}$. ed. $)$ New YorkUSA, West publishing company. 